UNIVERSIDADE DE SÃO PAULO

FACULDADE DE ECONOMIA, ADMINISTRAÇÃO E

CONTABILIDADE

DEPARTAMENTO DE ADMINISTRAÇÃO

PROGRAMA DE PÓS-GRADUAÇÃO EM ADMINISTRAÇÃO

\title{
COMUNICAÇÃO BOCA A BOCA EM MEIO DIGITAL: UM ESTUDO EXPLORATÓRIO SOBRE O COMPORTAMENTO DO PÚBLICO IDOSO
}


Prof. Dr. Marco Antonio Zago

Reitor da Universidade de São Paulo

Prof. Dr. Adalberto Américo Fischmann

Diretor da Faculdade de Economia, Administração e Contabilidade

Prof. Dr. Roberto Sbragia

Chefe do Departamento de Adminsitração

Prof. Dr. Moacir de Miranda Oliveira Jr.

Coordenador do programa de Pós-graduação em Administração 


\title{
PRISCILLA SANTOS FARIA
}

\section{COMUNICAÇÃO BOCA A BOCA EM MEIO DIGITAL: UM ESTUDO EXPLORATÓRIO SOBRE O COMPORTAMENTO DO PÚBLICO IDOSO}

\begin{abstract}
Dissertação apresentada ao Programa de Pós-Graduação em Administração do Departamento de Administração da Faculdade de Economia, Administração e Contabilidade da Universidade de São Paulo, como um dos requisitos para a obtenção do título de Mestre em Ciências.
\end{abstract}

Orientador: Prof. Dr. Edson Crescitelli

SÃO PAULO 


\section{FICHA CATALOGRÁFICA}

Elaborada pela Seção de Processamento Técnico do SBD/FEA/USP

Faria, Priscilla Santos

Comunicação boca a boca em meio digital: um estudo exploratório sobre o comportamento do público idoso / Priscilla Santos Faria. -- São Paulo, 2017.

$143 \mathrm{p}$.

Dissertação (Mestrado) - Universidade de São Paulo, 2017. Orientador: Edson Crescitelli.

1. Comunicação em marketing 2. Comunicação boca a boca 3 . Meio digital 4.Idosos I. Universidade de São Paulo. Faculdade de Economia, Administração e Contabilidade. II. Título.

CDD -658.8 
Os anos ensinam muitas coisas que os dias jamais chegam a conhecer (Ralph Waldo Emerson) 

Dedico esta dissertação aos meus amores, que são as pessoas mais importantes da minha vida: Marco (in memorian), Rita, Raphael e Daniela. 



\section{AGRADECIMENTOS}

Agradeço a Deus e nossa senhora por terem me dado força, saúde, determinação e luz para cumprir este ciclo e superar todos desafios. Ao professor Dr. Edson Crescitelli por ter me dado apoio, orientação e inestimável contribuição teórica para realização desta dissertação.

Ao professor Guilherme Shiraishi, que compartilhou seu conhecimento, estando sempre disponível.

Ao professor Julio Figueiredo, que contribuiu em grande medida com a construção desta dissertação, fornecendo novas fontes de dados, com olhar criativo e inspirador.

Ao professor Dr. Andrez Veloso, por engrandecer meus conhecimentos durante as aulas. Ao professor Dr. Leandro Leonardo participante da banca de defesa, contribuindo com seus conhecimentos.

Ao professor Dr. Marcos Campomar, Profa. Dra. Ana Ikeda, Prof. Dr. Geraldo Toledo, Profa. Dra. Kavita Hamsa, Profa. Dra. Bernadete Marinho por terem compartilhado conhecimento, colaborado com a minha formação e por terem apresentado aulas tão dinâmicas e inspiradoras.

Agradeço também a Rita, minha mãe, Daniela, minha irmã e meus familiares que sempre estiveram presentes, me ajudando a manter o foco e me dando carinho.

Ao meu noivo Raphael Rufatto dos Santos, que me inspirou a seguir na carreira acadêmica, me mostrou, de forma apaixonante, a mágica que existe no mundo educacional, sempre esteve ao meu lado me dando apoio e conselhos, e que realizou a revisão textual de toda dissertação.

Agradeço ao professor Dr. Benny Kramer por acreditar em mim, por me incentivar no mundo acadêmico me orientando, escrevendo e pesquisando comigo. Muito do que sei devo a você.

Aos amigos profa. Tatiana Ferrara pela disponibilidade e conselhos, prof. Alexandre Salvador por compartilhar seu conhecimento e experiência com a técnica de análise de conteúdo, profa. Renata Peris pela companhia e conselhos, profa. Ohana Trajano e prof. João Luiz Carvalho pela amizade e carinho, Altair Camargo pela amizade e por compartilhar seu conhecimento.

Agradeço aos amigos do PPGA - Dani, Cynthia, Eloisa, Fabi -, da secretaria Cida, Francisco e Ana - pelo carinho e por todas orientações prestadas. 
Agradeço a todos entrevistados pela disponibilidade e atenção prestada, sem eles a execução deste trabalho não seria possível.

Agradeço a CAPES pelo apoio financeiro ao longo deste estudo.

A todos que me ouviram discorrer sobre este trabalho, colaborando com críticas, sugestões, estímulos, inspirações, mesmo não mencionados diretamente aqui, registro meu profundo agradecimento.

Agradeço a todos que direta ou indiretamente contribuíram para o desenvolvimento deste estudo, fazendo parte do meu processo de formação e transformação. 
O conhecimento é o antídoto do medo

(Ralph Waldo Emerson) 



\section{RESUMO}

O boca a boca em meio digital tem sido tema de várias pesquisas, mas atualmente algumas questões críticas permanecem desconhecidas. Nesse sentido, este estudo de caráter exploratório e qualitativo, tem como objetivo compreender questões críticas, nomeadamente motivações dos usuários idosos da internet que contribuem com o boca a boca em meio digital. O método adotado inclui revisão na literatura dos conceitos de comunicação de marketing/boca a boca, internet e idosos. Também abrange uma pesquisa de campo com entrevistas em profundidade com usuários da internet idosos, à luz do modelo de Ho e Dempsey (2010). O modelo identifica quatro motivações potenciais: inclusão, individualidade, afeição/altruísmo e controle, que são compreendidas pelos respondentes de forma parcial. Também foram encontrados novos itens como análise de perfil, boca a boca negativo e positivo, comunicação ativa, descontração, diversão, educação, o estímulo emocional e proliferação de ideia, que foram adicionadas como motivações potenciais para esse segmento.

\section{Palavras-chave}

Comunicação boca a boca, meio digital, idosos. 


\begin{abstract}
The eletronic word of mouth has been the subject of several researches, but currently some critical questions remain unknown. In this sense, this exploratory and qualitative study aims to understand the critical questions, namely motivations of elderly internet users which contribute with eletronic word of mouth. The method adopted includes a literature's concepts review of marketing communication/word of mouth, internet and elderly. It also covers a field research with in-depth interviews with elderly internet users, in the light of Ho e Dempesey's model (2010). The model identifies four potential motivations: inclusion, individuality, affection / altruism, and control, which are partially conceived by respondents. New items were also found such as profile analysis, negative and positive word of mouth, active communication, relaxation, fun, education, emotional stimulation and the proliferation of idea, which were added as potential motivations for this segment.
\end{abstract}

\title{
Key words
}

Word of mouth communication, digital media, elderly people. 


\section{SUMÁRIO}

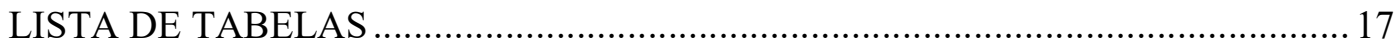

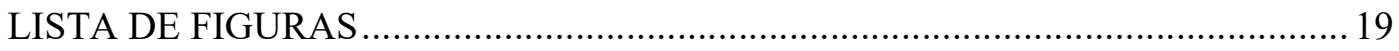

1 INTRODUÇÃO

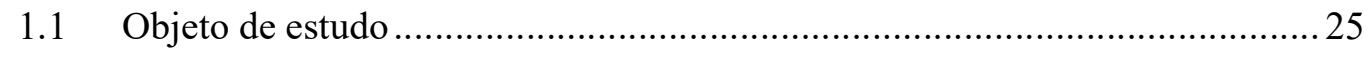

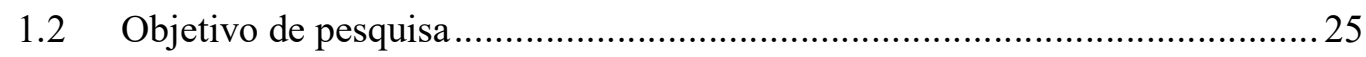

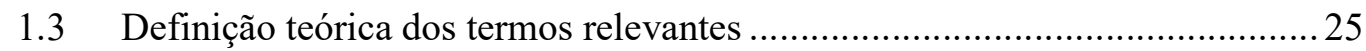

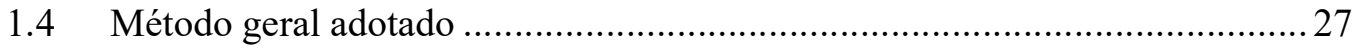

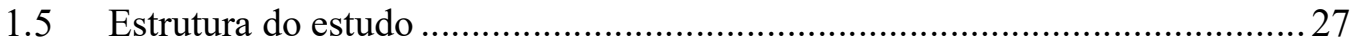

.

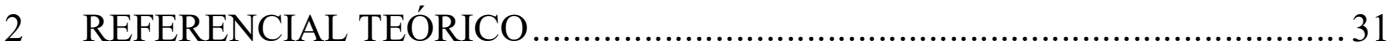

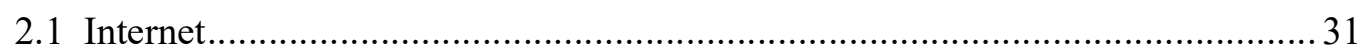

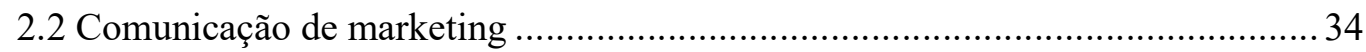

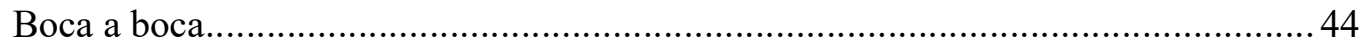

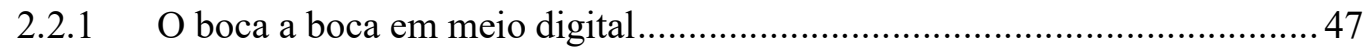

2.2.2 Boca a boca positivo e negativo ................................................................... 49

2.2.3 Motivação para a comunicação boca a boca..................................................5

Inclusão/A necessidade de fazer parte de um grupo/necessidade de atenção .........53

Individualidade/A necessidade de marcar a individualidade .................................53

Afeição/A necessidade de ser altruísta/mostrar apreciação e preocupação com os

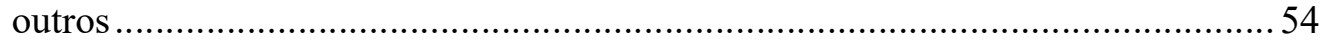

Controle - A necessidade de crescimento pessoal/necessidade de exercer poder no

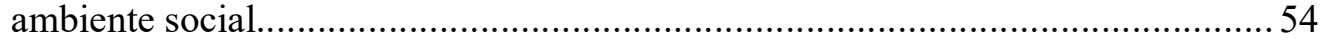

$2.3 \quad$ Idoso

2.3.1 O idoso e a comunicação digital .................................................................. 56

2.3.2 O idoso e as motivações para a comunicação digital ..........................................61

2.4 Interseção entre comunicação boca a boca, internet e o idoso ............................63

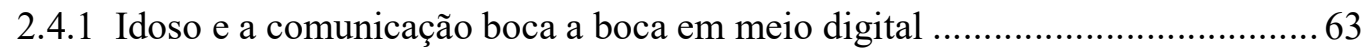

2.4.2 Motivações do idoso para comunicação boca a boca em meio digital................ 64

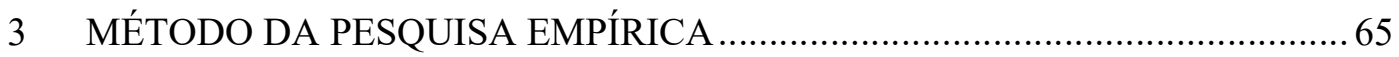

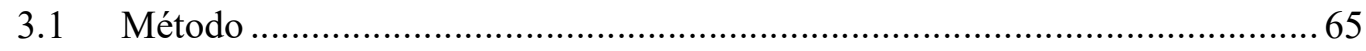

3.2 Definições do caráter, abordagem e procedimentos metodológicos de campo 66

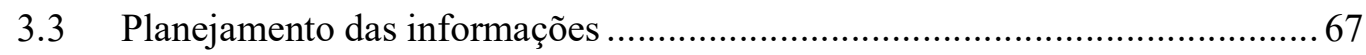

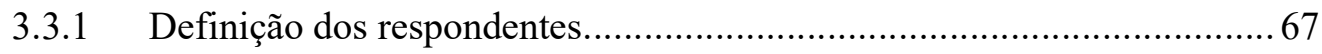

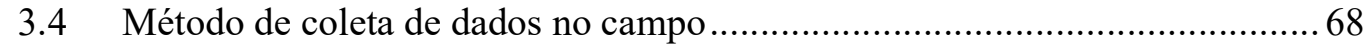

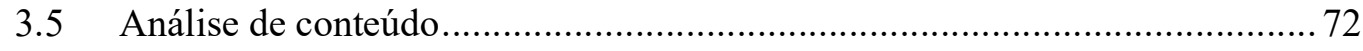


3.6 Entrevistas e transcrição de dados 77

4 ANÁLISE QUALITATIVA DE CONTEÚDO DOS DADOS EMPÍRICOS ....... 79

4.1 Análise Global e análise qualitativa de conteúdo.......................................79

4.3 Análise qualitativa de conteúdo das entrevistas baseada no referencial teórico 107

5 CONSIDERAÇÕES FINAIS

113

6 LIMITAÇÕES DA PESQUISA E SUGESTÕES PARA ESTUDOS FUTUROS 117

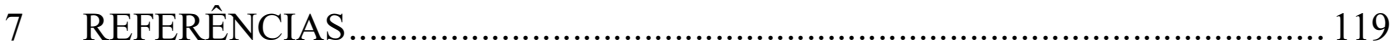

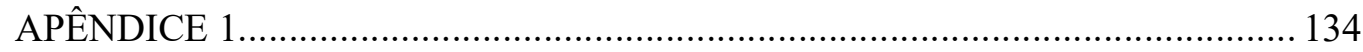

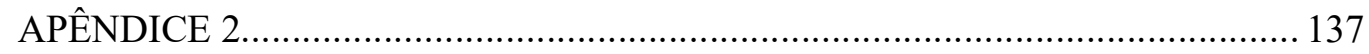

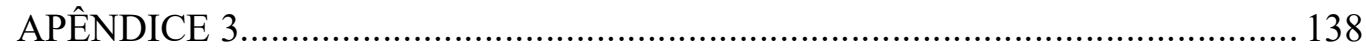

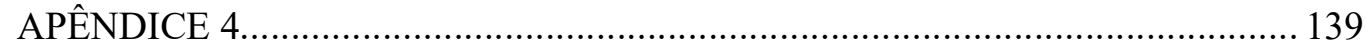

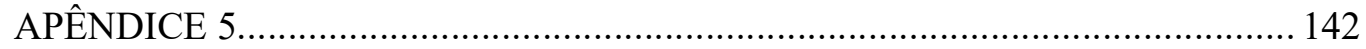




\section{LISTA DE TABELAS}

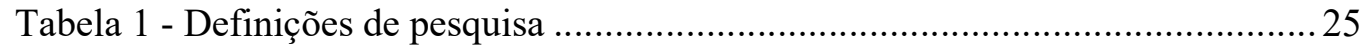

Tabela 2 - Perfil das formas de comunicação - mix de ferramentas ......................... 37

Tabela 3 - Definição de boca a boca ................................................................... 44

Tabela 4 - Tempo de uso da internet................................................................... 58

Tabela 5 - Definições para o roteiro de pesquisa................................................. 70

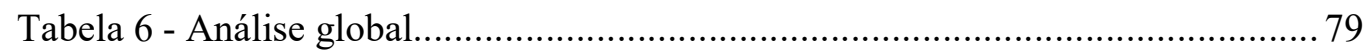

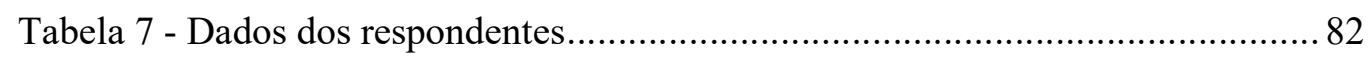

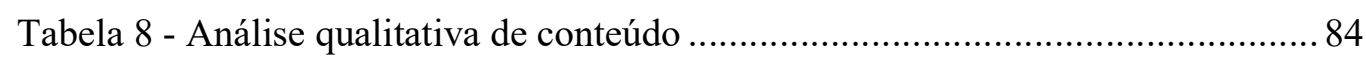

Tabela 9 - Descrito na literatura e verificado na pesquisa de campo..................... 107

Tabela 10 - Descrito na literatura, mas não verificado na pesquisa de campo......... 109

Tabela 11 - Não descrito na literatura, mas verificado na pesquisa de campo......... 110 



\section{LISTA DE FIGURAS}

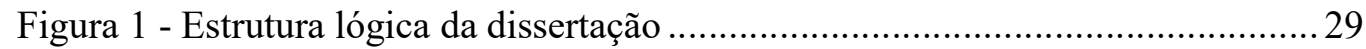

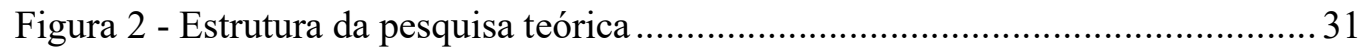

Figura 3 - Novo paradigma da comunicação.................................................... 41

Figura 4 - O efeito da internet e o fluxo de comunicação ........................................ 42

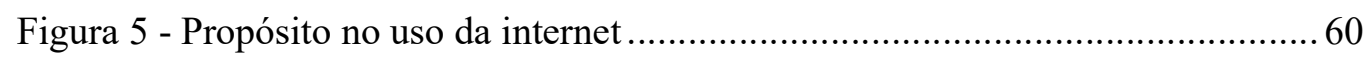

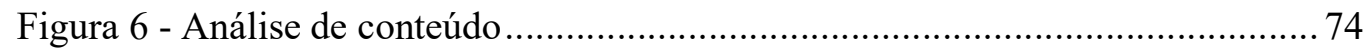

Figura 7 - Comunicação boca a boca - religião ................................................... 88

Figura 8 - Autoimagem - Maria Raimunda ….................................................... 90

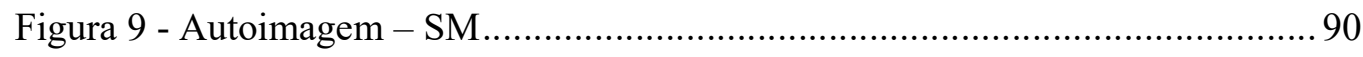

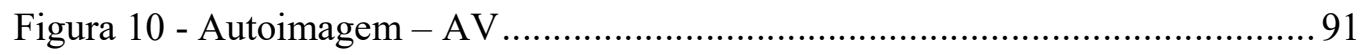

Figura 11 - Afeição/altruísmo - Decisão - Manuela................................................ 94

Figura 12 - Acolhimento emocional - MD ...................................................... 96

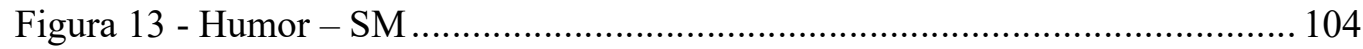

Figura 14 - Principais dimensões das motivações para eWOM dos usuários idosos da internet. 





\section{INTRODUÇÃO}

A comunicação de marketing é um aspecto crítico da missão geral de marketing das empresas e um fator importante para o sucesso ou fracasso delas. Por meio das ferramentas de comunicação de marketing, as empresas buscam promover suas ofertas e alcançar seus objetivos, que podem ser financeiros ou não (CRESCITELLI e SHIMP, 2012). Uma das formas mais tradicionais de comunicação de marketing é a comunicação boca a boca (GOYETTE et al., 2010). Para Ikeda (1997), a comunicação boca a boca é vital para criar relacionamentos de marketing duradouros, e se torna confiável por vir de pessoas não vinculadas à empresa, líderes de opinião, membros da família e amigos.

Mídias tradicionais como boca a boca, televisão aberta, rádio, jornais, revistas, ainda são bastante utilizadas pelas empresas, porém, desde o início da década de 90, as empresas também passaram a utilizar, em escalas menores, a mídia digital. A comunicação na internet, desde então, vem sendo realizada por meio de diversas ferramentas, como e-mails, blogs, redes sociais e sites, que proporcionam menores custos, mais facilidade de compartilhamento de informações e maior alcance aos consumidores em potencial (BRUYN e LILIEN, 2008). Uma vez que a comunicação vem sofrendo mudanças, as empresas precisam ter uma postura permanentemente de atualização e estratégias de marketing dirigidas para seus objetivos, haja vista algumas tendências marcantes como o aumento da utilização da internet, o consumo em tempo real e o crescimento dos mecanismos de busca (OKADA e SOUZA, 2011).

Com a internet, a comunicação boca a boca também sofreu mudanças. Na internet pode-se perceber a influência da opinião dos usuários sobre outros usuários e a importância dos laços sociais. Ho e Dempsey (2010), afirmam que amigos são fontes importantes de informações nas mais diversas atividades realizadas na internet, como reservas de viagens, pesquisas para o trabalho.

Nesse cenário dinâmico, são destacados como canais de comunicação a rápida

evolução da internet e a comunicação móvel (ANDRADE et al., 2013). Novos dispositivos como tablets e smartphones foram criados para facilitar a comunicação. Assim, já não se pode ignorar o papel da internet. A tecnologia digital e seu conjunto de plataformas provocaram transformações na comunicação, geraram um ponto de ruptura no tempo, mudando também os aspectos do comportamento do usuário ou consumidor (TERRA, 2011). 
Assim sendo, os profissionais de marketing têm buscado "tirar proveito das oportunidades que a internet oferece, atingindo públicos-alvo específicos com mensagens personalizadas e interativas em que os consumidores podem escolher quais conteúdos querem receber" (MACIAS, 2003, p. 36). Nesse contexto, pode-se perceber que as redes sociais têm sido utilizadas como fonte de informação (BARBOSA et al., 2015). As redes sociais são utilizadas como ferramentas que potencializam, dentre outras coisas, a comunicação boca a boca.

As empresas perderam o controle da informação, que agora circula sem censura e filtros entre consumidores, empresas e sociedade. Os consumidores não só utilizam a internet para realizar a busca de informações como também para transmitir o boca a boca em meio digital, repassando informações informais entre si de aspectos positivos e negativos de empresas (Ho e Dempsey, 2010; Bruyn e Lilien, 2008; Fazal et al. 2017), passam a se perceber como emissores em potencial de conteúdos, dotados de credibilidade entre seus pares e definiram uma nova forma de comunicação entre os consumidores (GENSLER et al., 2013; KAPLAN e HAELEIN, 2010; KLIATCHKO, 2008).

Embora seja possível reconhecer as atividades desenvolvidas pela área de comunicação de marketing e o seu papel nas mais variadas organizações, as significativas mudanças que estão ocorrendo nessa área estão fazendo com que o processo de comunicação se torne um grande desafio. Pires (2003), afirma que a comunicação boca a boca em meio digital é um instrumento de promoção poderoso que não tem seu potencial totalmente aproveitado.

Esse ambiente digital é propício para uma nova forma de comunicação entre empresas e consumidores. As informações espalham-se rapidamente e as empresas utilizam dessa ferramenta para aumentar o número de vendas, promover produtos, serviços e fortalecer a marca. Observa-se, então, que a relação entre a comunicação de marketing e o mundo digital é indissolúvel, especialmente no Brasil, que possui uma grande quantidade de usuários da internet interessados no compartilhamento das mensagens.

A revista Exame traz dados de uma pesquisa segundo a qual o Brasil está ranqueado como terceiro país que mais compartilha informações em redes sociais. E o Instituto Brasileiro de Geografia e Estatística (IBGE), com base nos dados do Suplemento de Tecnologias de Informação e Comunicação (TIC) da Pesquisa Nacional por Amostra de Domicílios (PNAD), informou que $54,4 \%$ da população brasileira tiveram acesso à 
internet. De acordo com Friedl e Vercic (2011), os blogs ou vídeos são mais populares para a partilha de comunicação de muitos para muitos. Isso aponta a importância de se analisar a comunicação boca a boca em meio digital para as empresas brasileiras. Nesse cenário, ganham destaque as redes sociais, que facilitam as conversas e fornecem oportunidades para compartilhar informações, especialmente grupos demográficos que ganham destaque, como os idosos que é um dos grupos que tem expandido com maior velocidade (JONES, 2002).

Uma pesquisa recente do Comscore constatou que $84,2 \%$ dos brasileiros acima de 55 anos estão conectados no Facebook. Segundo Wasserman et al. (2012), em um estudo realizado com um grupo de idosos da Universidade Federal do Rio Grande do Sul (UFRGS), a rede social predominante é o Facebook, representando $75 \%$ da preferência. Percebe-se que apesar de ainda ser pequeno o número de idosos que usam a internet não só no Brasil, mas em vários outros países (Lüders e Brandtzæg, 2017), os idosos que usam a internet estão cada vez mais engajados com a mídia digital e estão utilizando as redes sociais para o boca a boca.

Os idosos representam um grande segmento com renda disponível e poder de compra muitas vezes maior do que outros segmentos da população (ESTEVES et al., 2015, EAST et al., 2014). Tendo em alguns países, inclusive, aproximadamente o dobro da renda discricionária de seus filhos (Polyak, 2000).

Nesse cenário, percebe-se a importância de se analisar segmentos que estão ganhando destaque, em especial, o segmento dos idosos, pois esse nicho de consumidores impacta diretamente o mercado da indústria e do varejo (RILEY et al., 2015).

Embora a literatura discuta amplamente os benefícios das redes sociais, é necessário que haja uma pesquisa sobre desafios exclusivos relacionados ao compartilhamento das mensagens dos idosos e suas motivações. As motivações associadas com o boca a boca em meio digital têm influência de aspectos da vida das pessoas, como por exemplo saúde física, satisfação com a vida e segurança (Rubin e Rubin, 1992), o que leva a consideração de que aspectos motivacionais de boca a boca em meio digital podem divergir entre jovens e idosos.

Alguns estudos apontam as motivações que contribuem com o boca a boca em meio digital (Kaplan e Haenlein, 2011; Gladwell, 2002; Labsomboonsiri et al. (2017); Tang et al., 2016; Ho e Dempsey, 2010). No entanto, não existe consenso sobre essas motivações e, muitas vezes, os resultados apresentados se contrapõem (Almeida et al. 2011). Deste 
modo, não é claro como as motivações contribuem com o boca a boca em meio digital, especificamente dos usuários idosos da internet.

Portanto, foi examinada a literatura pertinente ao tema nas principais bases de dados, como Scopus e Web of Science, para identificar as motivações específicas relacionadas ao boca a boca em meio digital e para este trabalho foi adotado o modelo de Ho e Dempsey (2010), que possui as seguintes motivações:

(1) a necessidade de fazer parte de um grupo,

(2) a necessidade de marcar a individualidade,

(3) a necessidade de ser altruísta, e

(4) a necessidade de crescimento pessoal.

Embora a literatura sobre comunicação boca a boca se centre especialmente em informações relacionadas ao produto, as motivações para a e-WOM devem compartilhar algumas das mesmas características que as relacionadas a WOM. Também com a intenção de identificar motivações pertinentes para o boca a boca em meio digital, foi analisada a literatura sobre o uso da internet por idosos. Por fim, por razões que serão descritas em detalhes no capítulo nomeado "Motivação para comunicação boca a boca", usamos o estudo de Ho e Dempsey (2010) que se baseou na estrutura FIRO (Fundamental Interpersonal Relations Orientation - Orientação fundamental das relações interpessoais) para identificar os principais motivos associados ao boca a boca em meio digital.

Assim, diante da lacuna existente na literatura, da mudança na estrutura da população combinada com o considerável desenvolvimento tecnológico resultante do crescimento do uso da internet, é importante a compreensão das motivações para o boca a boca, pois poderia contribuir para melhores estratégias empresariais de comunicação, promoção, relacionamento com clientes e para futuras pesquisas da área acadêmica. Percebe-se que as novas vertentes da mídia digital no processo de comunicação boca a boca, o crescimento verificado do segmento dos idosos e os desafios de como lidar com este grupo, proporcionam novos campos de pesquisa tanto no âmbito acadêmico como no corporativo. Tendo em vista que para Schutz (1966), o processo de adoção e difusão da mensagem, ou seja, de comunicação boca a boca é uma função das características do indivíduo, há justificativa em se elaborar a seguinte questão de pesquisa para este estudo: como os idosos se comportam no meio digital em relação à comunicação boca a boca? 


\subsection{Objeto de estudo}

O tema dessa dissertação é a comunicação boca a boca dos usuários de internet idosos.

\subsection{Objetivo de pesquisa}

Diante do contexto e da questão de pesquisa apresentada no item "introdução", estabeleceu-se o seguinte como objetivo desse estudo: compreender as motivações para o boca a boca em meio digital dos usuários de internet idosos.

\section{Tabela 1 - Definições de pesquisa}

\begin{tabular}{|c|c|}
\hline Campo: & Marketing \\
\hline Assunto: & Comunicação estratégica \\
\hline Tema: & Comunicação boca a boca \\
\hline Pergunta problema: & $\begin{array}{c}\text { Como os idosos se comportam no meio digital } \\
\text { em relação à comunicação boca a boca? }\end{array}$ \\
\hline Objetivo de pesquisa: & $\begin{array}{c}\text { Compreender as motivações para o boca a boca } \\
\text { em meio digital dos usuários de internet idosos. }\end{array}$ \\
\hline
\end{tabular}

Fonte: elaborado pela autora

\subsection{Definição teórica dos termos relevantes}

Com a intenção de esclarecer termos usados nesse estudo, estabeleceu-se as seguintes definições teóricas:

\section{Motivação}

A motivação faz com que os consumidores mostrem seus comportamentos (Deci e Ryan, 1987). Para Vallerand (2000), são duas as categorias de motivações: extrínsecas e intrínsecas. A motivação extrínseca é impulsionada por benefícios externos e surge de fora de um indivíduo, como ganhar apoio social de outros (LIN, 2007). Já a motivação 
intrínseca é evocada por recompensas internas e se origina dentro de um indivíduo, como por exemplo o relaxamento, ou seja, estar livre de tensões (KOZAK, 2002). Para Labsomboonsiri et al. (2017) essas duas motivações (prazer e vínculo social) desencadeiam o boca a boca em meio digital.

Para o desenvolvimento desse estudo, será considerada motivação os estímulos que interferem no comportamento para a realização da comunicação boca a boca em meio digital. Os entrevistados selecionados por conveniência para participar da pesquisa de campo desse estudo realizam a comunicação boca a boca em meio digital e possuem Facebook para observação no período das entrevistas, atendendo aos critérios da pesquisa.

\section{Comunicação boca a boca}

Arndt (1967, p. 295) conceitua a comunicação boca a boca como uma comunicação oral, de pessoa para pessoa, entre o receptor e um comunicador, em que o receptor não identifica uma relação comercial quanto a uma marca, produto ou serviço. Bentivegna (2002) aponta que quando os consumidores divulgam a empresa para outros consumidores, eles estão realizando a comunicação boca a boca, potencializando o processo de disseminação. O receptor da mensagem se torna ativo compartilhando o conteúdo. Com base em sua definição teórica, neste estudo, referiu-se à comunicação boca a boca como qualquer mensagem interpessoal trocada entre emissor e receptor em que o emissor não represente comercialmente uma empresa.

Para Andrade (2006), o boca a boca em meio digital é o marketing viral. Para o autor, o marketing viral atua estrategicamente capturando a atenção do consumidor e possibilita que um receptor (passivo) se torne um emissor (ativo), influenciando seus

receptores na internet. Nesse trabalho, portanto, conceituamos marketing viral como comunicação boca a boca.

\section{Meio digital}

Considera-se como meio digital nesse trabalho a internet, especificamente sites e aplicativos de redes sociais. No meio digital, Gaber e Wright (2014), consideram o Facebook com rede social. 


\subsection{Método geral adotado}

O estudo é exploratório, não conclusivo. A pesquisa exploratória visa aprofundar o conhecimento sobre assuntos pouco explorados (GIL, 2007). Como o objetivo deste estudo é compreender as motivações para o boca a boca em meio digital dos usuários de internet idosos, o estudo exploratório com entrevista em profundidade é pertinente por fornecer dados mais detalhados para uma análise mais aprofundada.

Para Aaker et al. (2001) na pesquisa exploratória os métodos são mais flexíveis, não estruturados e qualitativos. Assim, o pesquisador começará seu estudo sem preconcepção do que encontrará, pois a ausência de rigidez permite que o pesquisador investigue diferentes ideias sobre a situação estudada.

A dissertação está dividida em duas principais partes: a primeira envolve por meio do levantamento do arcabouço teórico nas principais bases de dados como Scopus e Web of Science a pesquisa de dados secundários sobre comunicação de marketing/boca a boca, internet e idoso, permitindo a análise dos principais autores dos temas e o embasamento para a pesquisa de campo com as entrevistas em profundidade. A segunda parte envolve a pesquisa de campo com entrevistas em profundidade. A triangulação dos dados levantados na pesquisa de campo será feita com a observação das comunicações boca a boca realizadas nas páginas da rede social Facebook dos entrevistados.

O método deste estudo será detalhadamente apresentado no capítulo "método da pesquisa empírica”.

\subsection{Estrutura do estudo}

Para responder à questão de pesquisa, este trabalho está organizado em capítulos consecutivos da seguinte maneira: introdução, referencial teórico, método da pesquisa empírica, análise qualitativa de conteúdo dos dados empíricos, considerações finais, limitações da pesquisa e sugestões para estudos futuros e referências.

A introdução apresenta a contextualização do estudo, a importância do estudo com o tema escolhido, a pergunta de pesquisa, o objetivo de pesquisa, o método geral e a estrutura desta dissertação.

Já o segundo capítulo, denominado referencial teórico, apresentará a revisão da literatura - que será a base para o roteiro de entrevistas - sobre os seguintes itens: internet, apontando sua evolução e importância; comunicação de marketing, mostrando onde está 
localizado e como está relacionado o tema de pesquisa deste estudo; boca a boca, apontando a importância deste tipo de comunicação e as motivações para a sua realização; o idoso e a comunicação digital, que mostra o panorama do idoso no meio tecnológico; interseção entre boca a boca, idoso e a internet, que é o cerne deste estudo.

Em seguida, no terceiro capítulo, é apontado com detalhes o método da pesquisa empírica desse estudo qualitativo e exploratório, utilizado para responder à pergunta de pesquisa, os motivos para aplicação do estudo nos usuários de internet idosos, e como será a análise dos dados empíricos.

A análise qualitativa de conteúdo dos dados empíricos forma o quarto capítulo, e apresenta a análise do material coletado em campo. O quinto capítulo contempla as considerações finais baseada na análise dos dados empíricos e os dados do capítulo dois denominado referencial teórico, mostrando as contribuições deste estudo.

O sexto capítulo apresenta as limitações do estudo e as sugestões para futuros estudos e o sétimo e último capítulo trata das referências. 
Figura 1 - Estrutura lógica da dissertação

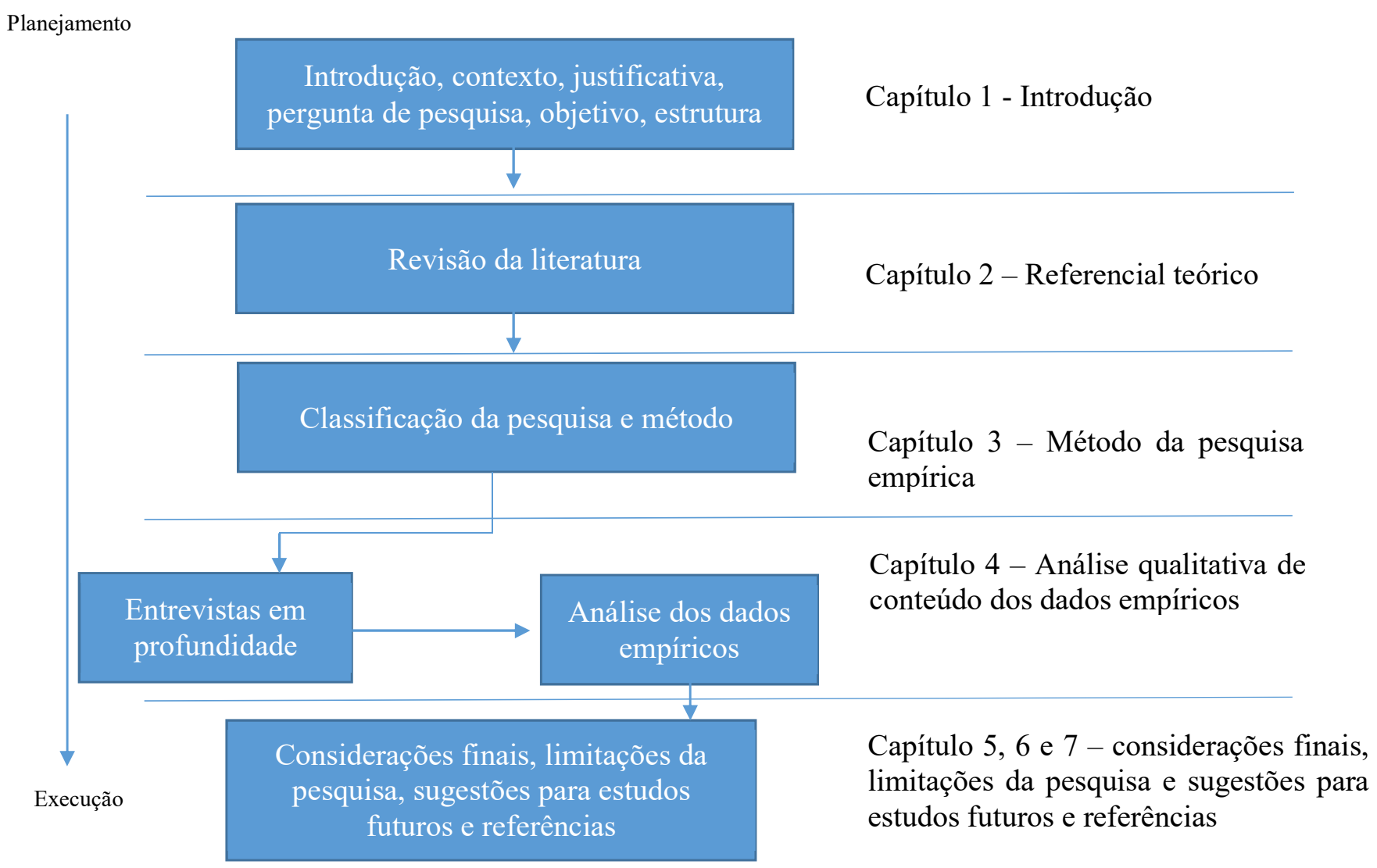

Fonte: elaborado pela autora 


\section{REFERENCIAL TEÓRICO}

Foi realizado um levantamento junto à literatura pertinente, focando-se nas seguintes bases conceituais: internet; comunicação de marketing, boca a boca, motivação para a comunicação boca a boca, boca a boca em meio digital; idoso, idoso e a comunicação digital; a interseção entre comunicação boca a boca, internet e o idoso (figura abaixo).

Figura 2 - Estrutura da pesquisa teórica

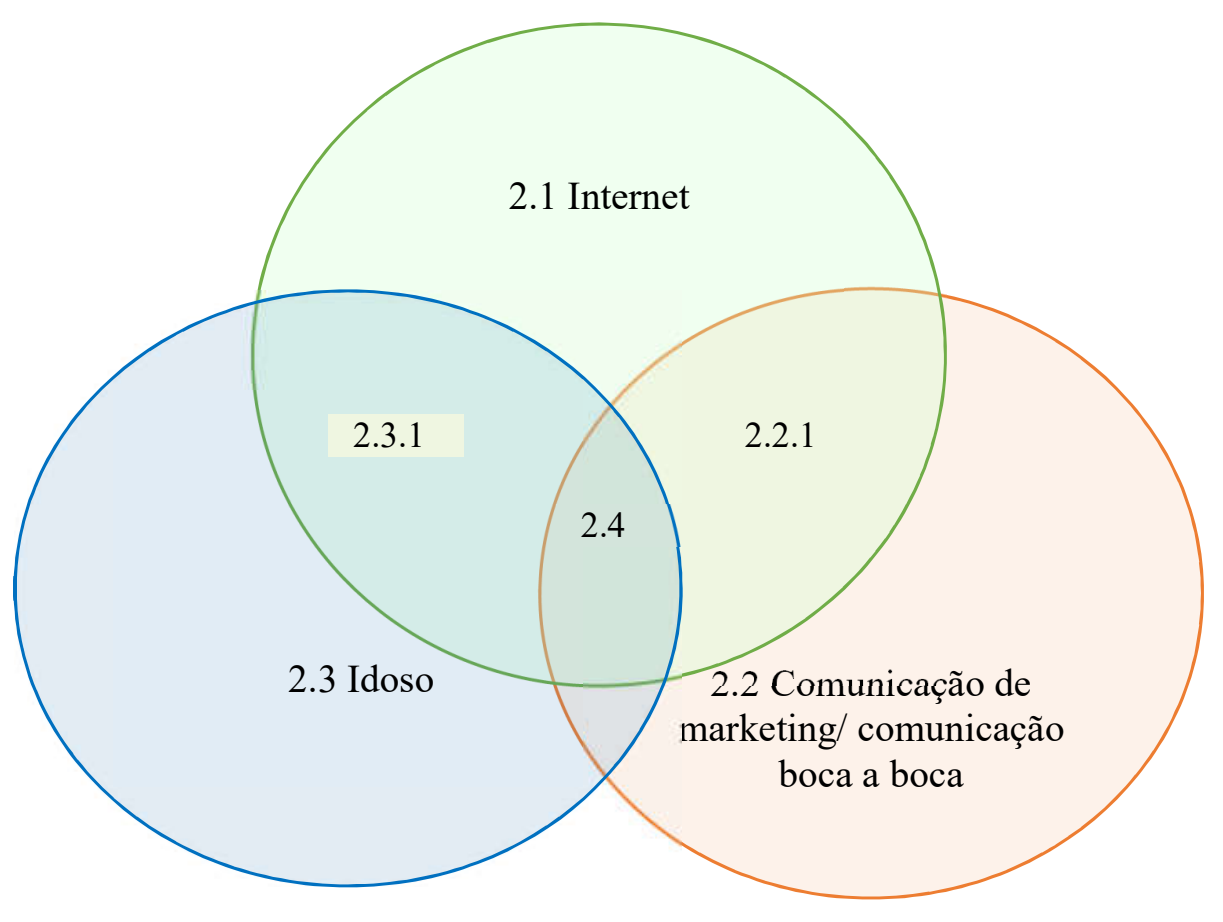

Fonte: elaborado pela autora

\subsection{Internet}

A tecnologia pode ajudar as empresas a realizar seus controles, gerar renda e facilitar diversos processos (BRYNJOLFSSON e HITT, 2000). Para Bruwer et al. (2015) a internet é o meio de publicação com o crescimento mais rápido de todos os tempos. E 
essa massa de informações não estruturadas pode apresentar novas oportunidades para as empresas. Com tantas informações, ela atua como um facilitador, tendo passado por processos evolutivos, do estático para a interação.

A primeira fase da internet (1.0), era mais estática (Bruwer et al., 2015), os sites eram trabalhados de maneira isolada, com conteúdo e funcionalidades desintegradas. As páginas dos sites eram mais estáticas. Com a segunda fase (2.0), foi criada uma sustentação teórica para as mudanças que ocorriam na internet. Em linhas gerais, referese a uma segunda geração de serviços e aplicativos da rede, recursos, tecnologias e conceitos que possibilitam um maior grau de interatividade e colaboração do usuário na internet. Passou a existir uma melhor estrutura de funcionalidade e os conteúdos são mais integrados nos sites.

Para Bruwer et al. (2015) a próxima fase (3.0) já está em andamento. Ela implica em uma fase em que há uma integração com a internet, em que a máquina poderá entender e catalogar dados de uma maneira semelhante a dos humanos. Isso facilitará um armazenamento de dados mundial em que qualquer formato de dados poderá ser compartilhado e entendido por qualquer dispositivo em qualquer rede.

A fase 3.0 não é representada pelo surgimento de uma nova internet, mas sim por uma extensão das tecnologias já presentes na internet 2.0. O conteúdo de dados na internet está se tornando mais diversificado e o volume mais abertamente disponível (Bergman, 2001). Tendo essa nova fase em vista, as empresas precisam estar prontas para os novos desafios e oportunidades que poderão surgir.

Proporcionando diversas possibilidades de interação, a internet, entre as empresas e seus públicos de interesse, cria novas formas de sociabilização, é dinâmica e apresenta uma linguagem própria. É fato que o processo de comunicação mudou muito com os avanços tecnológicos estabelecidos pela internet com novos modus faciendi e modus operandi (modo de fazer e modo de operar), que foram se sofisticando à medida que as tecnologias e a evolução do conhecimento foram se aperfeiçoando. Já não se pode ignorar o seu papel.

A internet potencializa as formas de publicação, compartilhamento e informações, além de ampliar os espaços para a interação entre os participantes (BRUWER et al., 2015). Com ela houve uma mudança no paradigma comportamental, o trabalho colaborativo e coletivo foi potencializado. Para Kotler et al. (2010), os profissionais de marketing não possuem total controle sobre as marcas, os consumidores desempenham 
um papel cada vez mais importante na geração de valor para os produtos e serviços da empresa, e demandam abordagens de marketing colaborativas.

Nesse contexto, ganham destaque os espaços para troca de informação como as redes sociais. As redes sociais são sites na internet que permitem a criação e o compartilhamento de informações e conteúdos pelas pessoas e para as pessoas, nas quais o consumidor é ao mesmo tempo produtor e consumidor da informação. Elas recebem esse nome porque são sociais, ou seja, são livres e abertas à colaboração e interação de todos, e porque são mídias, ou seja, meios de transmissão de informações e conteúdo. (TORRES, 2009, p. 113).

De acordo com Recuero (2009), pode-se definir uma rede social como o conjunto de dois elementos: atores (pessoas, instituições ou grupos) e suas conexões (interações ou laços sociais). Em síntese, as redes sociais têm como finalidade o compartilhamento de informações e a união de grupos de pessoas que buscam objetivos comuns (GOMES e MONDO, 2016).

Para Gaber e Wright (2014), hoje o aumento das redes sociais é muito evidente e não demonstra nenhum sinal de recuo. As redes sociais tornaram-se uma parte essencial da vida das pessoas, pois elas usam para interação social, para se manterem conectados com seus amigos e colegas, para se manter atualizado sobre tudo o que eles estão interessados e para compartilhar informações sobre bens e serviços de que são fãs. Além disso, as mídias sociais ajudam os usuários criarem seus próprios conteúdos sobre o que eles gostaram ou não, dando espaço para que os usuários se expressem em uma comunidade virtual.

A introdução de sites de redes sociais mudou o cenário de comunicação. Com a popularidade desses sites entre os consumidores e o aumento do tempo que eles passam navegando nesses sites devido a grande quantidade de interação social que ocorre entre eles, o efeito desses sites em influenciar o comportamento dos consumidores também aumentou (Hutter et al., 2013). As redes sociais proporcionam uma mudança de poder dos produtores tradicionais de informações, ou seja, as empresas, para consumidores que criam e distribuem seu próprio conteúdo (Denegri-Knott, 2006; Heinrichs et al., 2011). Essas mudanças fizeram com que os comerciantes começassem a adotar as mídias sociais amplamente em suas atividades de marketing. Deste modo, a interação entre clientes potenciais e atuais e as empresas possibilita a reunião de informações úteis para a área de marketing das empresas (GABER e WRIGHT, 2014). 
As modificações trazidas pela internet não se restringem ao ambiente virtual, elas se estendem para vários setores da sociedade, aos hábitos sociais e proporcionam novas possibilidades para as empresas. Ao analisar a internet, Gosh (1998), identificou quatro oportunidades que as empresas podem ter ao utilizarem a internet nas estratégias de marketing: possibilidade de construir uma ligação direta com os clientes, fornecedores ou distribuidores; antecipar ou ignorar outras empresas dentro do mercado; desenvolver e entregar novos produtos para novos clientes; tornar-se dominante no setor em que atua ou em um segmento específico. Percebe-se então, que a internet realiza uma função multifacetada, servindo como mecanismo estratégico para o marketing.

\subsection{Comunicação de marketing}

A comunicação de marketing coopera com a essência do marketing, que é o desenvolvimento de trocas entre empresas e clientes com o objetivo de beneficiar a todos (CHURCHILL, 2000). Ao definir o conceito de comunicação de marketing, Castro (2007) faz a seguinte afirmação:

A comunicação de marketing abrange o conjunto dos meios de que uma empresa se serve para trocar informação com o seu mercado. Por conseguinte, contempla tanto a comunicação de fora para dentro (ex: estudos de mercado), como a comunicação de dentro para fora (ex: publicidade). (p.29)

A comunicação de marketing possui características controláveis, e pode ser entendida como a troca de informações entre as empresas e seus diversos públicos. Os objetivos das trocas de informações são persuadir, informar, aumentar o market share, alcançar maiores rentabilidades, valorizar os atributos e benefícios dos produtos, fortalecer a marca e apontar diferenciais competitivos da empresa. Nessa mesma perspectiva, Galão e Crescitelli (2015, p.437) afirmam que “a comunicação de marketing ganha destaque pelo reconhecimento de suas múltiplas contribuições, uma vez que é capaz de transmitir aos diferentes públicos de interesse os diferenciais competitivos de uma organização, valorizar os benefícios e os atributos de seus produtos, contribuir para a criação de uma imagem de marca consistente e distinta da dos concorrentes, bem como auxiliar na construção e manutenção do relacionamento com os clientes". Na visão de Keller (2001), a comunicação de marketing pode ser utilizada para mostrar aos consumidores como e por que um produto é utilizado, quem o fabrica, por que tipo de 
pessoa e também onde e quando ele pode ser utilizado. $\mathrm{O}$ autor ainda afirma que a comunicação pode transmitir valores e significados que ultrapassam a natureza física dos produtos, apontando possíveis diferenciações entre os competidores do mercado.

O processo de desenvolvimento da comunicação envolve várias decisões, como a linguagem a ser adotada, os meios de comunicação, a seleção do público alvo, a determinação do orçamento a ser utilizado, quais os critérios e métricas para avaliação desse processo. Para Galão e Crescitelli (2015, p.439), “as decisões de comunicação não são feitas de forma isolada dos demais elementos do composto de marketing, tampouco são determinadas de forma independente das diretrizes estabelecidas no planejamento de marketing e documentadas no plano de marketing".

O planejamento da comunicação de marketing se desenvolve a partir da interrelação de algumas etapas que permitem à empresa determinar os planos estratégicos e operacionais da atividade. Engel et al. (2000) e Fill (2002), propõem modelos que permitem a inter-relação das etapas do planejamento da comunicação de marketing. Galão e Crescitelli (2015), em seu estudo analisaram dez empresas e verificam que as suas etapas adotadas para o planejamento da comunicação de marketing são: coleta e análise das informações, determinação dos objetivos, estabelecimento das estratégias de comunicação, confecção do plano de comunicação, aprovação e implantação.

Durante todo o processo de comunicação de marketing, as informações transmitidas pela empresa devem estar integradas com as suas estratégias, contribuindo para melhores resultados. Os autores ainda afirmam que as mensagens de marketing são direcionadas para os diferentes segmentos-alvo determinados pela organização a partir do processo amplo de segmentação de mercado, seleção de alvo e posicionamento. Atualmente, os mercados estão cada vez mais segmentados e são atingidos por uma grande quantidade de informações comerciais, o que mostra um grande desafio para as empresas desenvolverem suas comunicações. Assim, para evitar essa dissonância, as comunicações devem atuar de forma integrada, transmitindo mensagens que dialoguem com o público de interesse da empresa (CRESCITELLI e FIGUEIREDO, 2011).

Desde a década de 80, com o objetivo de alcançar melhores resultado, as empresas passaram a ter a necessidade de desenvolver estratégias para integrar suas ferramentas de comunicação (Belch e Belch, 2008). Com a abertura dos portos brasileiros na década de 90, as empresas se depararam com o mundo globalizado, capaz de impactar no comportamento social e de consumo. Assim, o desafio nesse cenário dinâmico de integrar as ferramentas de comunicação torna-se cada vez mais complexo. E as empresas passam 
a utilizar diversas formas de comunicação simultaneamente para melhorar a eficiência de suas mensagens (CRESCITELLI e FIGUEIREDO, 2011).

A comunicação integrada de marketing (CIM) é definida por Shimp (2009) como um processo de comunicação que abrange o planejamento, a criação, a integração e a implementação de diversas formas de comunicação (publicidade, promoção de vendas, eventos, etc) que são lançadas ao longo do tempo para os clientes ou clientes potenciais almejados de uma marca. A CIM amplia a integração com o mercado, cria consciência da marca, apresenta a identidade corporativa, representa os serviços e produtos ofertados pela empresa. Para que a CIM promova esses efeitos, é necessário que se compreendam as suas características críticas, e ao conceituar o entendimento da filosofia da CIM, Crescitelli e Shimp (2012) apontam os seguintes itens: o consumidor ou empresa consumidora deve representar o ponto de partida para todas as atividades de comunicação de marketing; deve-se usar de toda e qualquer ferramenta de comunicação de marketing que seja adequada à tarefa; mensagens múltiplas devem falar com uma voz única (um tema central); e não se deve perder o foco do objetivo final, que é afetar o comportamento.

Indiferentemente do meio em que se estiver usando, o entendimento da filosofia da CIM deve ser incorporado. Revistas, jornais, internet, todos eles devem reproduzir a mensagem de forma integrada para o mercado-alvo com o posicionamento desejado. A internet, especificamente, é um espaço de organização sinérgica, de transações, composta por informação e conhecimento, o que permite o desenvolvimento da CIM (LÉVY, 1999; RUDIGER, 2011). Cabe à empresa no processo de CIM levar aos públicos-alvo a sua mensagem de valor, levando em conta as diferentes possibilidades que o mix promocional proporciona. Nesse sentido, Geargeoura (2007) cita que diferentes ferramentas, técnicas e meios de comunicação podem ser utilizados pela organização no processo de garantir "espaço" adequado e valorizado para a imagem do seu produto ou serviço na mente do cliente, e com isso satisfazê-lo em sua avaliação e influenciar sua decisão de compra, procurando com isso garantir sua preferência

A comunicação de marketing tem sido aprimorada ao longo do tempo, e atualmente muitas são as formas utilizadas para comunicação entre as empresas e seus consumidores. Propaganda, eventos, promoção de vendas, relações públicas, patrocínio, marketing direto, boca a boca são algumas das formas de comunicação. Nesse estudo, será dado enfoque ao boca a boca em meio digital, ou seja, o marketing viral (ANDRADE et al., 2006). O boca a boca em meio digital tem papel cada vez mais relevante no desempenho das organizações, especialmente por estar centrado no consumidor. Embora 
tenha uma ampla capacidade para alcançar consumidores quando bem desenvolvida, a sua ação não deve carregar consigo a responsabilidade de divulgar uma campanha publicitária inteira sozinha. Os profissionais da área aconselham que campanhas de marketing viral utilizem também outras mídias de apoio para explorar melhor as características do produto ou da marca anunciados (BARICHELLO e OLIVEIRA, 2010).

Existem estudos que discutem a efetividade da propaganda desde a introdução do conceito da CIM na década de 90 (SILVA et al., 2012; GALÃO et al., 2011). Para Ikeda e Crescitelli (2003), a propaganda não perdeu sua importância ou utilidade no processo, mas o mix de comunicação é utilizado de forma mais balanceada. As formas de comunicação, como promoção de vendas, venda pessoal, merchandising e marketing direto - denominadas como "bellow the line" - começam a ganhar mais espaço, em detrimento da diminuição do espaço ocupado pela propaganda, que detinha a hegemonia no processo de comunicação de mercado. Contrapondo Ikeda e Crescitelli (2003), Belch e Belch (2008) apontam uma perspectiva que mostra o papel desempenhado pela comunicação de marketing nas grandes corporações multinacionais ou pequenos varejistas cada vez mais depende da propaganda e da promoção para ajudá-las a comercializar seus produtos e serviços.

Para que a comunicação de marketing seja efetivada, as formas de comunicação são elementares. Cada forma possui funções e características distintas, e nenhuma delas é capaz de atender os objetivos da comunicação quando atuam sozinhas. Deste modo, para que o resultado final seja efetivo, o uso combinado e integrado das formas na mídia digital e offline é recomendável. As formas mais comumente utilizadas na mídia digital são: marketing digital, marketing viral, buzzmarketing e redes sociais. A tabela três aborda as ferramentas online e offline, agrupadas como tradicionais, complementares e inovadoras, com respectivas formas, conceitos, características e efeitos.

Tabela 2 - Perfil das formas de comunicação - mix de ferramentas

\begin{tabular}{|c|c|c|c|}
\hline FORMA & CONCEITO & CARACTERÍSTICA & EFEITO \\
\hline TRADICIONAIS & & & \\
\hline PROPAGANDA & Criação de imagem & $\begin{array}{l}\text { A principal função da propaganda é } \\
\text { criar imagem para o produto/marca que } \\
\text { possa transmitir o posicionamento } \\
\text { desejado. Trata-se na maioria das } \\
\text { vezes de uma forma paga. }\end{array}$ & longo prazo \\
\hline
\end{tabular}




\begin{tabular}{|c|c|c|c|}
\hline PUBLICIDADE & Criação de imagem & $\begin{array}{l}\text { Sua função é similar à da propaganda, } \\
\text { mas com a diferença de que sua } \\
\text { veiculação não é paga, como é a da } \\
\text { propaganda. }\end{array}$ & longo prazo \\
\hline PROMOÇÃO & $\begin{array}{l}\text { Agregação de } \\
\text { benefício extra }\end{array}$ & $\begin{array}{l}\text { A função da promoção é estimular a } \\
\text { venda, por meio da oferta de benefício } \\
\text { extra e temporário. }\end{array}$ & curto prazo \\
\hline $\begin{array}{l}\text { RELAÇÕES } \\
\text { PÚBLICAS }\end{array}$ & $\begin{array}{l}\text { Formação e manutenção } \\
\text { de imagem }\end{array}$ & $\begin{array}{l}\text { A prioridade é manter a boa imagem da } \\
\text { empresa junto à comunidade na qual o } \\
\text { cliente está inserido e pela qual é } \\
\text { influenciado. }\end{array}$ & longo prazo \\
\hline PATROCÍNIO & Associação de imagens & $\begin{array}{l}\text { Também visa criar uma imagem como } \\
\text { a propaganda e a publicidade, porém } \\
\text { faz isso por meio da associação com a } \\
\text { imagem já existente. }\end{array}$ & $\begin{array}{c}\text { médio e longo } \\
\text { prazos }\end{array}$ \\
\hline MARKETING DIRETO & $\begin{array}{c}\text { Contato personalizado } \\
\text { e interativo }\end{array}$ & $\begin{array}{l}\text { O marketing direto atinge o público- } \\
\text { alvo de forma personalizada. O nível } \\
\text { de individualização e de interação é } \\
\text { variado. }\end{array}$ & curto prazo \\
\hline VENDA PESSOAL & $\begin{array}{l}\text { Contato presencial } \\
\text { e interativo }\end{array}$ & $\begin{array}{l}\text { A venda pessoal é a forma de } \\
\text { comunicação mais persuasiva de } \\
\text { comunicação, porém sua abrangência é } \\
\text { limitada. }\end{array}$ & curto prazo \\
\hline \multicolumn{4}{|l|}{ COMPLEMENTARES } \\
\hline MERCHANDISING & Exposição & $\begin{array}{l}\text { As ações de merchandising visam dar } \\
\text { maior visibilidade ao produto ou marca } \\
\text { no ponto-de-venda ou fora dele, como } \\
\text { em locais públicos e programas de TV } \\
\text { e filmes. A intenção é reforçar (e não } \\
\text { formar) a imagem. }\end{array}$ & $\begin{array}{c}\text { curto e médio } \\
\text { prazos }\end{array}$ \\
\hline $\begin{array}{l}\text { MARKETING DE } \\
\text { RELACIONAMENTO }\end{array}$ & $\begin{array}{c}\text { Contato personalizado } \\
\text { e interativo }\end{array}$ & $\begin{array}{l}\text { Envolve clientes já conquistados e tem } \\
\text { a função de manter a imagem e o nível } \\
\text { de relacionamento }\end{array}$ & médio prazo \\
\hline MARKETING DIGITAL & Contato virtual & $\begin{array}{l}\text { Uso da mídia digital para se comunicar } \\
\text { com público de interesse (ex. site, } \\
\text { compras, notícias, e-mail marketing) }\end{array}$ & $\begin{array}{l}\text { Médio e longo } \\
\text { prazos }\end{array}$ \\
\hline EVENTOS TÉCNICOS & Associação de imagens & $\begin{array}{l}\text { Feiras, congressos, seminários, } \\
\text { exposições, shows. }\end{array}$ & Médio prazo \\
\hline PRODUCT PLACEMENT & Criação de imagem & $\begin{array}{l}\text { Inserção de produtos em programas de } \\
\text { televisão, filmes ou mídias digitais }\end{array}$ & Longo prazo \\
\hline
\end{tabular}




\begin{tabular}{|c|c|c|c|}
\hline INOVADORAS & & & \\
\hline ADVERTAINMENT & Criação de imagem & $\begin{array}{l}\text { Inserção de uma mensagem de } \\
\text { marketing em uma atividade de } \\
\text { entretenimento }\end{array}$ & $\begin{array}{l}\text { Médio e longo } \\
\text { prazo }\end{array}$ \\
\hline MARKETING VIRAL & $\begin{array}{c}\text { Compartilhamento da } \\
\text { imagem }\end{array}$ & $\begin{array}{l}\text { Compartilhamento de mensagem entre } \\
\text { usuários da internet }\end{array}$ & Curto prazo \\
\hline BUZZMARKETING & $\begin{array}{c}\text { Compartilhamento da } \\
\text { imagem }\end{array}$ & $\begin{array}{l}\text { Estimulo para que determinado } \\
\text { assunto torne-se um burburinho }\end{array}$ & Curto prazo \\
\hline REDES SOCIAIS & $\begin{array}{l}\text { Relacionamento e } \\
\text { criação da imagem }\end{array}$ & $\begin{array}{l}\text { Plataforma de interação B2B, B2C e } \\
\text { C2C }\end{array}$ & $\begin{array}{c}\text { Médio e longo } \\
\text { prazos }\end{array}$ \\
\hline $\begin{array}{l}\text { VISUAL } \\
\text { MERCHANDISING }\end{array}$ & $\begin{array}{l}\text { Posicionamento da } \\
\text { marca }\end{array}$ & $\begin{array}{l}\text { Proposta de design interior para } \\
\text { transmitir os valores da marca }\end{array}$ & Médio prazo \\
\hline MOBILE MARKETING & $\begin{array}{l}\text { Relacionamento e } \\
\text { criação da imagem }\end{array}$ & $\begin{array}{l}\text { Ações entre empresas e consumidores } \\
\text { por meio do celular }\end{array}$ & Curto prazo \\
\hline STORYTELLING & Criação de imagem & $\begin{array}{l}\text { Narrativas que transmitem o } \\
\text { posicionamento e criam a imagem da } \\
\text { empresa }\end{array}$ & Longo prazo \\
\hline
\end{tabular}

Fonte: baseado em Kotler (2000: 585), Nickels \& Wood (1999: 323), Crescitelli e Shimp (2012), Ogden e Crescitelli (2007:24) e Ikeda (1997).

A comunicação de marketing foi modificada com o advento da internet, a comunicação digital trouxe novos desafios. As mudanças envolvem novas tecnologias e proporcionam uma nova relação entre as empresas e seus públicos de interesse. Para Cravens e Piercy (2007), os desafios decorrentes de profundas mudanças com as quais os executivos do mundo todo estão sendo confrontados são complexos e surgem cada vez mais rapidamente.

Bertocchi (2006) condensa as visões apresentadas pelos autores Fidler (1997), Hayles (1999), Lunenfeld (2000), Murray (2001), Manovitch (2001), Salaverría (2005), que recebem mais destaque, com a tríplice narrativa, condicionando as formas comunicacionais da internet à hipertextualidade, multimedialidade e interatividade. Em consonância com Bertocchi (2006, p.57), Salaverría (2005) entende por hipertextualidade a capacidade de conectar diversos textos digitais entre si. Define a multimedialidade como a capacidade outorgada pelo suporte digital de combinar em uma mesma mensagem pelo menos dois dos três seguintes elementos: texto, imagem e som. E por interatividade entende a possibilidade que o usuário tem de interagir com a informação apresentada pelo cibermeio. 
De acordo com Crescitelli e Shimp (2012), seriam exemplos de comunicação digital: os e-mails e as redes sociais, que são importantes canais de comunicação entre empresas e consumidores atuais e potenciais.

Os diversos exemplos de comunicação pela internet tornam-se interessantes para as empresas porque podem proporcionar aos anunciantes uma ampla gama de possibilidades para dirigir suas mensagens aos públicos-alvo. Essas mensagens podem ser transmitidas para pessoas de uma determinada empresa, para certas regiões geográficas, em horários programados, baseadas em buscas e preferências de usuários encontradas na internet. Os sites permitem que as empresas, com a autorização dos usuários, rastreiem os hábitos desses internautas, mostrando como esses interagem com marcas, produtos e anúncios. Por meio desses sites, pode-se quantificar o desempenho da comunicação digital, analisando o número de cliques, perfis acessados, volume de vendas. Os usuários, por sua vez, podem se comunicar com as empresas com mais facilidade pela internet. O canal fica acessível sempre para o usuário, e os clientes podem acessar em diversos lugares por computadores, tablets e smartphones.

A internet possibilita forte interação e alta velocidade entre empresas e seus clientes, assim a comunicação ocorre de muitos para muitos. O cliente não assume somente o papel passivo de receptor de mensagens, mas também o de desenvolvedor de conteúdo, atuante com o poder de decisão frente a tantas possibilidades de escolha que a internet disponibiliza por meio das empresas que a utilizam. Assim, Muniz e Feuser (2012), afirmam que a chave para entender todas essas mudanças é a transferência de poder de quem faz, cria e distribui as mensagens para quem está do outro lado, ouvindo e recebendo as mensagens.

A forma como as empresas e os seus consumidores se comunicam passou por algumas significativas transformações: fácil acesso à informação, comunicação dinâmica, papel mais ativo dos consumidores em relação às empresas, compartilhamento de opiniões entre consumidores sobre produtos, consumidores controlando a informação. Assim, mensagens, opiniões, críticas são trocadas e repassadas entre as diversas pessoas que estão na mídia digital em qualquer lugar, a qualquer hora. As empresas perderam o controle da informação, que agora circula quase sem censura e filtros entre consumidores, empresas e sociedade. 
Figura 3 - Novo paradigma da comunicação

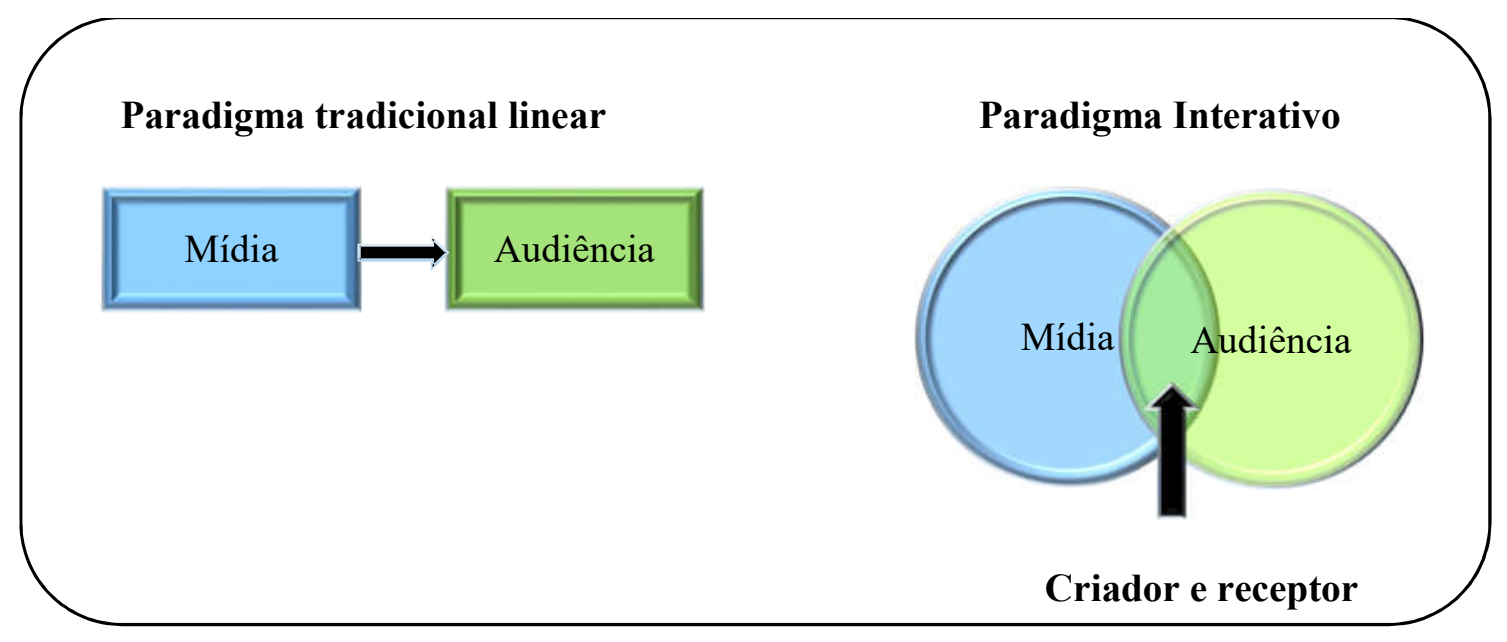

Fonte: adaptado de Kliatchko, 2008, p. 17.

A voz do consumidor ganhou amplitude graças à internet e ao aparecimento das mídias sociais. Ao se juntarem nas mídias sociais, as pessoas estão sanando suas necessidades de pertencimento e reconhecimento de pares que compartilham normas, valores e interesses (LAROCHE et al., 2012). Sobre esse acontecimento, Kotler (2012), afirma que cada vez mais as comunicações interpessoais ocorrem dentro do ambiente da internet, em chats, fóruns, mídias sociais ou listas de discussão em que milhares de pessoas trocam informações e opiniões sobre produtos e serviços. Pires (2003), afirma que a comunicação boca a boca em meio digital é um instrumento de promoção poderoso que não tem seu potencial totalmente aproveitado.

Em concordância com essa inversão de poderes, Donaton (2007) afirma que essa pequena sentença está mudando todo o mercado: de um modelo de comunicação tradicionalmente invasivo para um modelo baseado no poder de decisão do consumidor. Agora é ele que escolhe como e quando as mensagens vão ser recebidas. Entretanto, percebe-se que na mídia digital, muitas vezes, o consumidor sente-se invadido por diversas propagandas, rastreamentos que estão vinculados aos aplicativos disponibilizados pelas empresas. Nesse sentido, os consumidores são bombardeados por anúncios a partir do remarketing e banners disponíveis nos sites, que nem sempre os interessam ou têm integração com as ferramentas de marketing da própria empresa.

A intensificação do fluxo de comunicação é maior na internet do que em outras mídias em que o receptor da mensagem assume um papel passivo de comunicação, somente recebendo a informação. $\mathrm{Na}$ internet, o receptor pode interagir com a empresa, 
optar por dar informações, gerar um relacionamento e não somente uma mera recepção e transmissão. A intensificação do fluxo de comunicação ocorre entre empresas e consumidores, entre a sociedade como um todo, entre empresas, órgãos públicos, entre outros. Crescitelli e Shimp (2012) explicam que tradicionalmente o fluxo de informações era controlado pela empresa e direcionado ao consumidor. Posteriormente, esse fluxo tornou-se de mão dupla, com maior interação entre as duas partes. Depois da internet, a sociedade também passou a fazer parte desse processo, gerando um novo vértice no processo de comunicação. As informações circulam livremente entre essas três partes, e a empresa não tem mais o controle do conteúdo nem da intensidade das informações.

\section{Figura 4 - $O$ efeito da internet e o fluxo de comunicação}

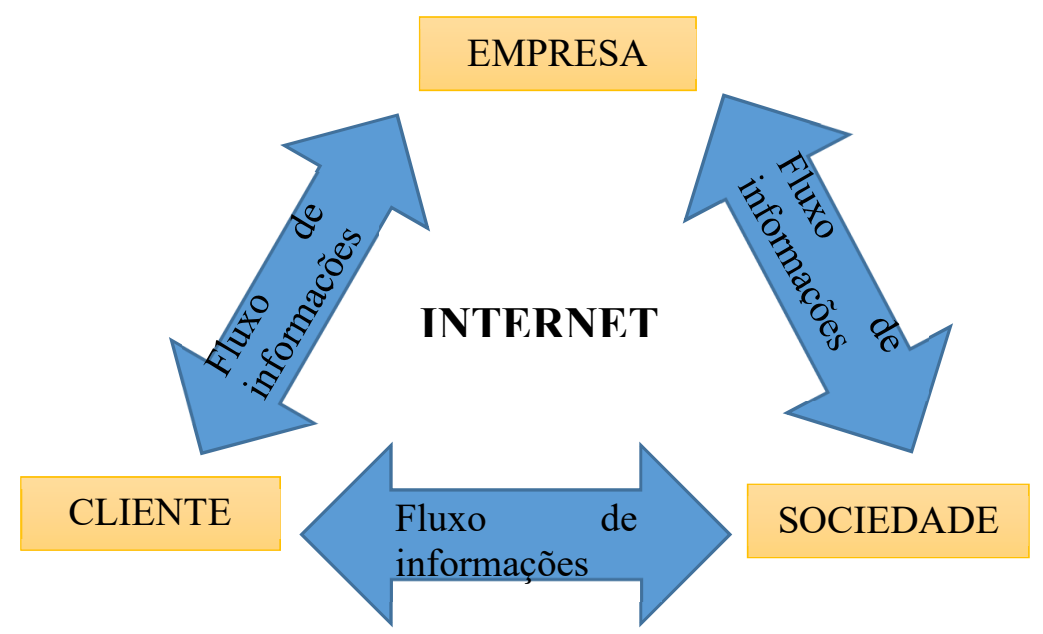

Fonte: Crescitelli e Shimp (2012).

Esse cenário incentiva a pesquisa em comunicação digital, permite que os pesquisadores conheçam os perfis de consumo de seus participantes a partir de suas práticas. Tendo a internet um meio rico para a comunicação a partir do aumento do número de usuários (Hine, 2005), ela se torna interessante para elucidar que além da evolução tecnológica, questões da sociabilidade e apropriação são imprescindíveis para as estratégias empresariais: "o agente de mudança não é a tecnologia em si, e sim os usos e as construções de sentido ao redor dela (HINE, 2004, p. 13)".

Segundo Bruwer et al. (2015) a internet tornou-se um elemento de estratégia indispensável, pois se uma organização ou um profissional deseja se manter competitivo 
no mercado, precisa considerar o fato de que a internet vai ser um de seus recursos, para os autores, a internet se tornou a principal fonte de comunicação em todo o mundo. Ou seja, a comunicação digital é um campo importantíssimo para pesquisas e estratégico para as empresas. Karjaluoto et al. (2015), apontam que a comunicação digital é uma das mais importantes ferramentas de comunicação de marketing, e que as empresas estão utilizando a comunicação digital para melhorar o relacionamento com o cliente, o suporte de vendas e gerar reconhecimento. Os autores ainda afirmam que as empresas não têm usado as mídias sociais e redes sociais como parte de mídia digital tão amplamente como ferramentas digitais tradicionais.

Estudos recentes de mídias digitais têm focado as suas investigações na análise de benefícios, limites e pré-requisitos estruturais de estratégias online (Treem e Leonardi, 2012; Moreno et al. 2015). A análise das práticas online e os canais na mídia digital também são assuntos recentes na comunicação digital (Friedl e Vercic, 2011; Wright e Hinson, 2012).

Ao que se refere aos canais preferidos para o recebimento de informações, Friedl e Vercic (2011), em seu estudo demonstram que informações e notícias vindas de sites são mais utilizados. Já para transmissão de informações sobre a empresa, são preferidos canais, como boletins informativos por e-mails, e informações de intranet a mídias sociais. No entanto, os autores ainda afirmam que os blogs ou a partilha de vídeos são mais populares no caso da comunicação de muitos para muitos. Blogs e o compartilhamento de vídeos são preferidos a todos os outros meios de comunicação sociais, o que mostra a influência da opinião dos usuários da internet sobre outros usuários.

Existem alguns estudos que falam sobre o compartilhamento das mensagens nas mídias digitais (Bentivegna, 2002; Barichello e Oliveira, 2010). No entanto, Royle e Laing (2014), afirmam que a literatura sugere lacunas de competências na comunicação digital, como falta de conhecimentos técnicos específicos, necessidade de melhor orientação prática sobre as métricas de avaliação e ausência de uma visão de futuro para as mudanças tecnológicas dinâmicas proporcionadas na internet. 


\section{Boca a boca}

A comunicação boca a boca (WOM - word of mouth) é uma das mais importantes estratégias utilizadas pela área de comunicação. Trata-se da comunicação interpessoal, estabelecida dentro do domínio das relações humanas, caracterizada pela força das ligações entre as partes envolvidas, com elevado poder persuasivo (PIRES, 2003). O boca a boca é o processo de transmitir informações de pessoa para pessoa, tanto online ou offline (STANDING et al., 2016).

Kotler e Armstrong (1998), argumentam que a comunicação boca a boca pode surgir a partir da utilização das ferramentas promocionais como propaganda, venda pessoal, relações públicas, promoção de vendas. Essas quatro ferramentas do composto promocional do mix de marketing possibilitam a interação dos consumidores com outros públicos, possibilitando o surgimento do boca a boca. Com variadas conceituações, surge a necessidade de elencar seu significado por alguns autores:

\section{Tabela 3 - Definição de boca a boca}

\begin{tabular}{|c|c|}
\hline Autor & \multicolumn{1}{c|}{ Conceito } \\
\hline Arndt (1967, p. 295) & $\begin{array}{c}\text { Trata-se de uma comunicação oral, pessoa a } \\
\text { pessoa, entre o receptor e um comunicador, na } \\
\text { qual o receptor não percebe uma relação comercial } \\
\text { quanto a uma marca, produto ou serviço. }\end{array}$ \\
\hline Bone (1992, p. 579) & $\begin{array}{c}\text { Fenômeno grupal, na forma de troca de } \\
\text { comentários individuais, pensamentos, e ideias } \\
\text { entre dois ou mais indivíduos em que nenhum } \\
\text { deles representa uma fonte de marketing. }\end{array}$ \\
\hline Harrison-Walker (2001, & $\begin{array}{c}\text { Boca a boca é uma comunicação informal entre um } \\
\text { comunicador percebido como não comercial e um } \\
\text { dado receptor, relacionada a uma marca, a um } \\
\text { produto, a uma organização, ou a um serviço. }\end{array}$ \\
\hline Hennig-Thurau et al. \\
$\begin{array}{c}\text { (2004, p39) } \\
\text { A comunicação boca a boca em meio digital é }\end{array}$ \\
$\begin{array}{c}\text { qualquer declaração positiva ou negativa feita por } \\
\text { produto ou empresa, disponibilizado para uma } \\
\text { infinidade de pessoas e instituições por meio da } \\
\text { internet. }\end{array}$
\end{tabular}

Fonte: elaborado pela autora 
Nas definições acima entende-se o boca a boca como um comportamento envolvendo pelo menos duas pessoas, em que o emissor da mensagem não deve ser percebido como alguém ligado à empresa, produto ou marca referida na mensagem ao receptor. Contrariando Arndt (1967), que estava em um período que não sofria influência do meio digital, Butle (1998) afirma que as ações de boca a boca não têm de ser necessariamente presenciais, e muito menos orais, assim, percebe-se a importância dada ao fluxo da informação e a informação, sem prestigiar o meio.

Desde a década de 50, o fluxo de informações e o julgamento dos consumidores têm recebido muita atenção. Nas pesquisas sobre WOM a influência das pessoas sobre outras pessoas, o fluxo de informações e o julgamento dos consumidores têm recebido muita atenção (KATZ e LAZARSFELD, 1955). Desde então, pesquisadores têm estudado como o boca a boca influencia o consumo. Questões como a influência na percepção dos consumidores, aspectos psicológicos para as motivações dos ouvintes e influenciadores, o efeito positivo que o boca a boca positivo gera sobre as vendas também são apontadas (DICHTER, 1966; ARNDT, 1967).

Em 1967, apresentando a importância e as aplicações da comunicação boca a boca, Arndt (1967) organizou 147 estudos relacionados à boca-a-boca em diversas áreas, como sociologia, psicologia e marketing. O autor afirmava que esse tipo de comunicação informal era, possivelmente, o mecanismo mais antigo para opinar sobre marcas, produtos etc. Bass (1969) desenvolveu um modelo de difusão que abrangia os princípios tratados por Fourt e Woodlock (1960) e Mansfield (1961). Nesse modelo o autor assumiu que os consumidores potenciais de uma inovação são influenciados por dois processos: a comunicação de massa e a comunicação interpessoal.

Reynolds e Darden (1971), estudaram os efeitos mutuamente adaptativos da comunicação interpessoal, sugerindo novos conceitos à comunicação interpessoal e sua influência nas atitudes e nos comportamentos futuros. Midgley (1983), em seu estudo apontou o uso de informações interpessoais para a compra de produtos. Já Richins (1983) apontou o boca a boca negativo gerado pela insatisfação de consumidor. E Mahajan et al. (1984), afirmou que a comunicação boca a boca colabora com a introdução de novos produtos.

A partir da década de 90, os estudos sobre comunicação boca a boca foram intensificados. Relacionando os efeitos da comunicação boca a boca com a informação 
de atributos específicos na avaliação de produtos, indicando o impacto da comunicação no julgamento dos produtos (HERR et al., 1991).

Kapferer (1993, p.176) afirmou que "os consumidores têm mais confiança no que dizem seus vizinhos ou amigos do que na publicidade ou nos revendedores”. Em razão disso, as empresas preocupam-se ainda mais com a comunicação boca a boca e em como lançar um comentário a respeito de seu produto para aumentar as vendas. O autor enfatiza que o alvo para a divulgação da informação boca a boca pode ser caracterizado como o líder de opinião, que é uma pessoa que goza de certa influência junto ao seu ambiente, mesmo não tendo consciência disto, tendo, porém, o hábito de opinar, o que normalmente é esperado.

Duhan et al. (1997), em consonância com Kapferer (1993), em sua pesquisa afirmam que as comunicações boca a boca vindas de fontes de informações pessoais são grandes influências para as tomadas de decisão de compra e que as mensagens compartilhadas de amigos do trabalho possuem mais credibilidade do que as mensagens de empresas. Na pesquisa de Ikeda (1997) e Jenkins (2014), a comunicação boca a boca é aceita e é confiável porque vem de líderes de opinião, membros de família, amigos e outras fontes não relacionadas oficialmente com as empresas. Complementarmente a Duhan et al. (1997) e Ikeda (1997), Riquelme et al. (2016), em um estudo mais recente, analisam como a decepção pode influenciar a satisfação do consumidor, e consequentemente a comunicação boca a boca torna-se importante no comportamento pós-compra.

Rosen (2001), indica que as empresas utilizem as ferramentas tradicionais de comunicação, como por exemplo a propaganda, para tornar os produtos conhecidos, aumentando e mantendo o boca a boca. Ao contextualizar sobre a importância de aumentar e manter o boca a boca, Rosen (2001), afirma que existem três razões elementares: o ruído, o ceticismo e a conectividade. O ruído nas mensagens faz com que os clientes mal consigam ouvir o que as empresas dizem. Ademais, estão aprendendo a filtrar cada vez mais as informações, o que faz com que eles escutem seus amigos. Por sua vez, o ceticismo em relação ao que as empresas comunicam é um item que faz com que o boca a boca originado por amigos e conhecidos tenha mais credibilidade. Por fim, a conectividade dos consumidores na internet possibilita o acesso às informações de outros consumidores que se apresentam mais amigáveis, solidários e confiáveis do que as mensagens veiculadas pelas empresas. 


\subsubsection{O boca a boca em meio digital}

A facilidade de acesso à internet criou "um ambiente no qual as barreiras para publicação de dados desapareceram, transformando qualquer pessoa que possua uma boa conexão de Internet [...] em uma fonte confiável de informações” (BARGER, 2013, p.2). A internet vem modificando os hábitos das pessoas, trazendo informação e interação para seus usuários, e seus reflexos são percebidos pelas empresas, e em especial pelos gestores de comunicação de marketing. A comunicação digital, ou seja, a comunicação na internet, mostra-se importante, esse ambiente online é propício para uma nova forma de comunicação, o boca a boca em meio digital (HO e DEMPSEY, 2010). A internet fez com que as pessoas ganhassem mobilidade e interatividade (AMARAL, 2004, p.33).

Para Andrade (2006), o boca a boca em meio digital é o marketing viral. Por meio de mídias sociais e blogs, a exposição da opinião pessoal sobre experiências positivas e negativas na internet e seu compartilhamento tornaram-se fáceis. Para Standing et al. (2016), a comunicação boca a boca em meio digital ou eletrônico (eWOM) é uma força importante na construção de um mercado digital.

O estudo da eWOM tem implicações sobre como construir uma comunidade online por meio do design de rede social, comunicação na internet e troca de conhecimento. $\mathrm{O}$ uso inovador da eWOM tem benefícios significativos para empresas. Para Park e Lee (2009), o boca a boca em meio digital é uma importante estratégia de marketing que afeta o comportamento dos usuários da internet.

Na comunicação boca a boca, a mensagem se espalha em pouco tempo, com um mínimo orçamento e o máximo de eficiência. Para Andrade et al. (2006), o boca a boca aumenta o desejo do consumidor em participar ativamente do ambiente virtual, instigando-o a disseminar todos os interesses que o entretenham ou captem a sua atenção. Segundo os autores, atrair os consumidores, incitando-os ao alastramento da campanha pelo envio da mensagem àqueles com quem possuem relação online é o objetivo do boca a boca em meio digital.

Segundo Bentivegna (2002), o boca a boca ocorre quando os consumidores divulgam a empresa para outros consumidores. Desse modo, potencializa-se o processo de disseminação e autorreprodução ao tornar ativo o receptor da campanha. Desta forma, “o marketing viral atua no sentido estratégico de capturar a atenção do consumidor e possibilita a um receptor (passivo) se tornar um emissor (ativo), buscando influenciar sua rede de convivência social online" (ANDRADE, et al., 2006b, p.8). 
À medida que os usuários online e o tempo de navegação aumentam, as redes se tornam canais de marketing poderosos. O marketing nas redes sociais, influente hoje em dia, utiliza as redes sociais como o Facebook para permitir o compartilhamento de conteúdo, a difusão de informações, a construção de relacionamento e a coesão dos fãs (CHEUNG e LEE, 2010; KIM e KO, 2012). Rogers (1995) sugere que a comunicação boca a boca constitui importante aspecto para deliberações sobre a aquisição de novos produtos ou sobre o uso de inovacoes. Para o autor, a difusão é definida como o processo pelo qual uma inovação espalha-se entre os membros de um sistema social. Toda comunicação de uma inovação entre os membros de um sistema social caracteriza um processo de difusão.

As conexões nas redes sociais espalham facilmente as mensagens. Elas criam efeitos sinérgicos, tornando-se uma poderosa ferramenta de comunicação. Assim, os gerentes de marketing devem persuadir usuários de internet a compartilhar espontaneamente mensagens com parentes, colegas ou amigos. Portanto, a disseminação efetiva de informações torna-se um fator essencial no sucesso do marketing nas redes sociais, e persuadir os usuários da internet é primordial para pesquisas de marketing recentes (CHANG et al., 2015).

As redes sociais como o Facebook (curtidas, comentários, compartilhamentos) permitem a expressão de opiniões e de emoções (De Vriesa et al., 2012). Suspeitando das propagandas tradicionais, os usuários da internet preferem confiar em amigos ou informações vindas de pessoas desconhecidas da internet (CHANG et al., 2015). Muitas dessas informações espalham-se como vírus (GLADWELL, 2002).

Gladwell (2002), explica o que chama de "epidemias sociais". O autor sugere que ideias, produtos, mensagens e comportamentos se espalham como vírus. Esta relação se dá a partir de três características. Primeiramente, observa a capacidade de contágio existente tanto em vírus quanto em ideias. Em seguida, aponta para o fato de que uma ação, embora pequena, pode gerar um grande impacto. Enfim, denomina o "ponto de virada", o momento em que ocorrem mudanças de maneira drástica, ou seja, o efeito da viralização.

Atualmente, além da análise da participação da empresa e a repetição espontânea pelos receptores, alguns artigos sobre comunicação boca a boca abordam as questões éticas e legais (KOSTIĆ et al., 2015). Já o estudo de Hinz et al. (2011), afirma que pessoas bem conectadas também são mais propensas a participar de campanhas com comunicação boca a boca, mas não têm maior influência sobre os seus pares do que as pessoas menos 
conectadas. Outros estudos relacionam a comunicação boca a boca e as redes sociais (KAPLAN e HAENLEIN, 2011). As métricas para análise da eficácia das campanhas com a comunicação boca a boca também são assuntos recentemente estudados (Cruz e Fill, 2008; Ewing et al., 2014). Kim et al. (2011) analisam os motivos que levam os viajantes a consultarem as comunicações boca a boca em meio digital, apontando as diferenças existentes entre os gêneros. Assim, as mulheres, por exemplo, são mais propensas a ler revisões por conveniência, análise da qualidade e redução do risco. O uso da comunicação boca a boca online pelos homens depende do seu nível de experiência em agendamentos de viagem online.

A pesquisa de Lu e Stepchenkova (2015), examinou as postagens das mídias sociais para entender o contexto do boca a boca digital, identificando influenciadores chave. Finalmente, os artigos de 2017 trazem a aplicação do boca a boca em meio digital, sugerindo que os gestores devem investir em estimular tanto a gratidão do cliente quanto o comprometimento afetivo para melhorar as intenções positivas de boca a boca e posteriormente o envolvimento do cliente, apontando o efeito do impacto do boca a boca na marca (Fazal et al., 2017; Raguseo e Vitari, 2017). Percebe-se que a maioria dos estudos não mantém o foco no emissor da ação boca a boca, mesmo tendo o comportamento do consumidor como importante para os profissionais de marketing e suas estratégias (HARRISON-WALKER, 2001).

\subsubsection{Boca a boca positivo e negativo}

A satisfação do cliente tem sido ligada às suas intenções de compra (OLIVER, 1980). Clientes satisfeitos normalmente comentam sobre a sua experiência positiva (PWOM) para outros clientes (Swan e Oliver, 1989); por outro lado, os clientes insatisfeitos irão realizar o boca a boca negativo (NWOM) quando passarem por experiências insatisfatórias (ESTEVES et al., 2015). Portanto, há grande importância em gerar satisfação para que os clientes se tornem leais e gerem o boca a boca positivo (OLIVER, 1980; SWAN e OLIVER, 1989). Tendo em vista o fato de clientes terem o desejo de contar as outras pessoas suas experiências positivas e negativas (PWOM e NWOM). Assim, pode-se destacar esta premissa: 
Premissa 1: a relação das pessoas idosas usuárias de internet com marcas ou produtos comprados motiva o boca a boca em meio digital. Sendo positivo quando houver satisfação na relação com a empresa, e negativo quando houver maior insatisfação na relação com a empresa.

É importante também que as empresas cuidem para que o consumidor dotado de poder pela força da comunicação não atrapalhe suas estratégias de marketing, pois a comunicação boca a boca negativa poder ser bastante contraproducente.

Amezcua e Quintanilla (2016) realizaram uma avaliação qualitativa dos posts escritos no site oficial do YouTube da empresa Coca Cola, em que a marca pede aos consumidores que se juntem à empresa em uma brigada contra a obesidade. Os resultados ampliam o conhecimento atual sobre o boca a boca negativo dos consumidores, identificando três formas de estilos cínicos de comunicação do consumidor em resposta à campanha corporativa na rede social: céptica, passiva-agressiva e guerreiros.

Os cépticos percebem a incongruência, especialmente quando a empresa faz declarações concretas que podem ser facilmente comparadas às ações tomadas pela empresa na comunidade. Já os usuários passivos-agressivos não expressam diretamente que estão desiludidos ou decepcionados, podendo até mostrar que são amigáveis. No entanto, seus comentários provocam alguma resistência, evasão e uma falta de apoio. Os guerreiros, por sua vez, criticam abertamente e questionam as ações da empresa como uma estratégia de enfrentamento para lidar com suas emoções, que são frequentemente ligadas à raiva. Esses usuários usam da ironia para falar das propostas da empresa e fornecem evidências que contradizem o que a marca está comunicando. Para os autores, as discrepâncias recorrentes entre as campanhas de comunicação das corporações e suas ações transpõem os consumidores de uma perspectiva cética para uma queixa.

\subsubsection{Motivação para a comunicação boca a boca}

Embora não seja o único elemento responsável pelo sucesso das empresas, a comunicação boca a boca pode nelas ter grandes efeitos, o que suscita uma ampla literatura sobre este tipo de comunicação.

Como consequência de uma maior comunicação entre consumidores e consumidores mediada por computador nas mensagens de marketing da empresa, há uma 
necessidade crescente de entender essas interações digitais de forma mais explicita. Dada a crescente importância da comunicação boca a boca, os pesquisadores de marketing têm procurado identificar as motivações que mais contribuem com esse processo. Alguns estudos mostram como o impacto do envolvimento emocional interfere no compartilhamento das mensagens, apontam que fatores como humor, conteúdos agradáveis (positivos) resultam em maior compartilhamento. Existem alguns trabalhos na literatura que apontam as motivações para o boca a boca (Matos e Rossi, 2008; HennigThurau et al. 2004).

Arndt (1967), afirma que as motivações para a comunicação boca a boca estão relacionadas à busca de apoio social para tomada de decisão. $\mathrm{O}$ autor ainda sugere que o compartilhamento de informações e o conhecimento são mais importantes do que o controle social. De acordo com Berger e Milkman (2012), as pessoas compartilham informações, experiências e notícias por causa das informações úteis nelas contidas. Kasabov (2016), apontou a provisão de informação como o principal motivo de compartilhamento de informações na rede social pelos chineses. A provisão de informações engloba informações de produtos e fatos, experiências de usuários e avaliações de interações com empresas, produtos e serviços.

Ao que se refere a gerações mais novas que a dos idosos, como a geração Y nascidos a partir de 1980 (Smola e Sutton, 2002), em seu estudo, Zhang et al. (2017), afirmou em seu estudo que o uso ativo das mídias sociais e os seus pares tiveram uma influência radical sobre as suas intenções de realizar eWOM dos serviços experimentados. O uso da tecnologia móvel (celular) também influenciou o boca a boca positivo e negativo mais do que as experiências satisfatórias.

Labsomboonsiri et al. (2017), desenvolveram um estudo com a intenção de compreender por que os membros de comunidades de sites desenvolvem a necessidade de compartilhar e/ou desenvolvem o vínculo social dentro da comunidade. Os autores descobriram que aqueles membros que procuram suporte para solução de problemas em combinação com elementos de relaxamento estão mais inclinados a compartilhar com outros membros da comunidade e desenvolver uma ligação social dentro dessa comunidade. $\mathrm{O}$ que vai de encontro com a necessidade de apoio social para tomada de decisão apontada por Arndt (1967).

Sundaram et al. (1998), ao escreverem sobre WOM destacam que estamos mais inclinados a compartilhar mensagens que sejam úteis para nossa comunidade, sobre produtos ou marcas que somos orgulhosos de usar e sobre produtos que definem nossa 
personalidade. Contrariamente, Chung e Darke (2006) apontam que apesar do consumo de vários produtos, há com maior frequência o compartilhamento daqueles produtos e experiências que fortalecem a imagem pessoal que as pessoas querem projetar.

Em seu trabalho, Tang et al. (2016), afirmam que as duas motivações intrínsecas (senso de autoestima e socialização) e extrínsecas (recompensa econômica e reciprocidade) têm efeito positivo no compartilhamento de cupons digitais pelas redes sociais, por meio do celular.

Bentivegna (2002), identificou as principais características de uma ação eficaz de marketing boca a boca virtual, realizando uma pesquisa exploratória com usuários de internet. $\mathrm{O}$ autor identificou seis itens que podem influenciar o sucesso do marketing boca a boca virtual: familiaridade com a marca da empresa que realiza a ação de marketing viral, desenvolvimento de uma massa crítica de amplificadores da mensagem, baixa complexidade da mensagem, existência de incentivos para a replicação da mensagem, componente de diversão da mensagem, ineditismo da ação de marketing viral. Percebese que em seu estudo o autor da ênfase para algumas características da mensagem.

Embora haja uma literatura robusta sobre os antecedentes do boca a boca, as motivações, há também a ausência de consenso sobre suas motivações. Para Labsomboonsiri et al. (2017), ainda se sabe pouco sobre as motivações intrínsecas e extrínsecas que movem o boca a boca em meio digital. No melhor entendimento, de acordo com as pesquisas realizadas, nenhum estudo explorou especificamente as motivações para o boca a boca em meio digital dos idosos usuários da internet.

Com tantas teorias estabelecidas, há a implicação de compreender as reais motivações envolvidas na transmissão de informações de uma pessoa para outras já que o eWOM é tido como uma conversa entre duas fontes ou mais. Tendo isso em vista, foi adotado um arcabouço conceitual proposto por Ho e Dempsey (2010), pois fornece um quadro útil para integrar as diversas motivações que potencialmente estão subjacentes ao encaminhamento do conteúdo online: a necessidade de fazer parte de um grupo, a necessidade de ser individualista, a necessidade de ser altruísta e a necessidade de crescimento pessoal.

Ho e Dempesey (2010) se basearam na teoria estabelecida por Schutz (1966), que discorre sobre o comportamento interpessoal, se propõe a explicar porque ocorrem os engajamos na comunicação interpessoal. Schutz (1966) propôs uma teoria tridimensional do comportamento interpessoal que ele nomeou como FIRO (Fundamental Interpersonal Relations Orientation - Orientação fundamental das relações interpessoais). Para o autor, 
as pessoas estão envolvidas na comunicação interpessoal porque estão motivadas para expressar uma ou mais das três necessidades interpessoais: inclusão (precisa fazer parte de um grupo / necessidade de atenção), afeição (mostrar apreciação e preocupação com os outros) e controle (necessidade de exercer poder no ambiente social).

\section{Inclusão/A necessidade de fazer parte de um grupo/necessidade de atenção}

Para Schutz (1966), dentro da teoria FIRO, a inclusão, que é o desejo se ser identificável ou diferente das outras pessoas, está relacionada a necessidade de reconhecimento como participante em uma ação. Questões como pertencer, unir-se, juntar-se são importantes para pessoas com a característica de inclusão.

Assim, para essas pessoas, as motivações do boca boca na internet poderia estar relacionado à seguinte premissa:

Premissa 2: a necessidade de ter pelo menos uma relação interpessoal é uma motivação para a realização da comunicação boca a boca em meio digital.

\section{Individualidade/A necessidade de marcar a individualidade}

A motivação para comunicação boca a boca está alinhada com a autoimagem do indivíduo, ou seja, a divulgação de conteúdos que relacione características semelhantes às que o indivíduo tem de si mesmo. Conforme o estudo estabelecido por Chung e Darke (2006) os indivíduos eram mais propensos a realizar comunicação boca a boca de produtos alinhados com a sua autoimagem.

O envolvimento em eWOM se relaciona também a um importante motivador, que é o auto aperfeiçoamento (Sundaram et al. 1998). Do mesmo modo, Dichter (1966) aponta que os indivíduos criam seu senso de identidade com o compartilhamento do WOM para ganhar atenção e status. Para Vignoles et al. (2000) todo humano tem a motivação de se ver distinto dos outros.

As pessoas que marcam a sua individuação podem ser definidas de acordo com Maslach et al. (1985) como aquelas com vontade de se destacar ou ser diferente de outros. Em seu estudo, os autores apontam que as pessoas que marcam suas individualidades estão mais dispostas a expressar suas opiniões e a se destacar em uma comunidade. 
Chan e Misra (1990) propuseram que o ato de disseminar informações por meio da comunicação boca a boca faz com que os sujeitos se destaquem entre seus grupos, os torna diferentes dos outros membros. Assim, se estabelece a próxima premissa:

Premissa 3: O boca a boca em meio digital é motivado pela possibilidade de o indivíduo marcar sua identidade, se diferenciar.

\section{Afeição/A necessidade de ser altruísta/mostrar apreciação e preocupação com os outros}

Schutz (1966) aponta que a afeição é definida como a necessidade de manter um relacionamento satisfatório, levando os indivíduos a se engajarem em comportamentos relacionados à intimidade, ao acolhimento e ao envolvimento emocional. Para Price et al. (1995) as pessoas que desejam afeto buscam relacionamentos mais próximos e que tal necessidade está relacionada ao conceito de altruísmo. Ho e Dempsey (2010) e Dichter (1966) afirmam que os altruístas são indivíduos que realizam ações e compartilham informações com outros indivíduos baseadas em amor e afeição, sem interesse pessoal. A literatura de WOM em meio digital ou não aponta que muitas vezes as pessoas são motivadas pelo altruísmo (Phelps et al., 2004 ; Sundaram et al., 1998; Hennig-Thurau et al., 2004).

Premissa 4: O altruísmo motiva o encaminhamento online de mensagens por idosos usuários da internet.

\section{Controle - A necessidade de crescimento pessoal/necessidade de exercer poder no ambiente social}

Para Schutz (1966), o sentimento de competência, influência e realização está relacionado a necessidade interpessoal de controle. As pessoas com alta necessidade de controle precisam fazer a diferença em seu ambiente social e dizer como isso acontece.

A comunicação boca a boca nesse caso é uma chance para estabelecer oportunidades de desenvolvimento da carreira, por exemplo, de se comunicar com pessoas que auxiliem de algum modo no desenvolvimento pessoal. 
Para Ho e Dempsey (2010), o indivíduo pode ser motivado a realizar o WOM como um meio de desenvolver conhecimento ou experiência, influenciado pelo sentimento de desenvolvimento pessoal.

\section{Premissa 5: $O$ desenvolvimento pessoal motiva o boca a boca em meio digital.}

\section{$2.3 \quad$ Idoso}

O envelhecimento da população é inegável. O número de pessoas idosas no mundo todo tem crescido. De acordo com Agudo et al. (2012), o número de idosos da Espanha representa $16,6 \%$ da população e passará para mais de 30\% em 2050. Luyt et al. (2011) afirmam que em Cingapura, em 2050, a população idosa representará 39,8\% do total da população. Já no Brasil, os idosos configuravam, em 2010, um contingente aproximado de 19,6 milhões de pessoas, e de acordo com os resultados das projeções divulgadas pelo IBGE, esse número deve aumentar para 66,5 milhões em 2050. Nos Estados Unidos da América o volume de 70 milhões já será alcançado em 2030 (POLYAK, 2000). Esses dados comprovam o aumento da expectativa de vida em todo o mundo.

O envelhecimento da população mundial vem se acentuando nos últimos anos em função do aumento da expectativa de vida. Estima-se que existam 600 milhões de pessoas acima de 60 anos e que este número chegue a 2 bilhões em 2050, o que representa um mercado consumidor em franca expansão (MOSCHIS, 2003). No Brasil, de acordo com a secretaria nacional de promoção defesa dos direitos humanos, a população com 65 anos ou mais, que era de 4,8\% em 1991, passou a 5,9\% em 2000 e chegou a aproximadamente 7,4\% em 2010. As regiões sul e sudeste são as que apresentam as maiores proporções de idosos na população total, conservando a posição das regiões mais envelhecidas do país.

Apesar das alterações demográficas apontadas acima, Silvers (1997) argumenta que há um erro crucial na forma abordar e desenvolver produtos para este grupo. $\mathrm{O}$ autor aponta que elas não cobrem claramente a diversidade existente nos idosos, e que, como resultado, as empresas podem estar perdendo importantes oportunidades.

Antes da década de 1980 o segmento dos idosos foi totalmente negligenciado, tanto em termos de produtos quanto em pesquisas de mercado e da academia. A partir de 1980 isto começou a mudar. As primeiras publicações sobre este segmento apontaram para um grande segmento e com mais poder aquisitivo do que se imaginava, o que chamou a atenção dos profissionais de marketing. Em função da falta de informações confiáveis, as 
ações de marketing seguiam uma estratégia de "tentativa e erro". As empresas aprenderam com os próprios erros ao fazer comunicações voltadas para o estereótipo de "pessoas mais velhas". A partir dos anos 90, duas tendências foram verificadas: as empresas notaram a importância deste segmento e passaram a desenvolver produtos e estratégias de marketing voltadas para os idosos; a maneira como se comunicar com este segmento mudou, passando a ser muito mais cautelosa em função dos erros cometidos anteriormente (MOSCHIS, 2003). Muitas empresas ainda estão lutando para encontrar estratégias de comunicação eficazes para alcançar consumidores idosos (Moschis e Mathur, 2006).

De acordo com Montero, (2005), o século XIX foi caracterizado por um período com alta taxa de natalidade e elevada mortalidade. O século XX viu o fim da transição demográfica, a revolução da longevidade e do envelhecimento. Assim, o século XXI tem como desafio tornar a longevidade compatível com a autonomia pessoal e a participação social. Para Agudo et al. (2012), envelhecer não se limita a um momento específico da vida, o envelhecimento faz parte da sequência do desenvolvimento humano e, portanto, se a velhice for considerada como um processo contínuo, abre-se o caminho para a ação e rompe-se o caminho do preconceito. Nesse sentido, percebe-se cada vez mais que o número dos idosos está aumentando e o desejo de se manter ativo por estes idosos também.

O envelhecimento ativo é conceituado pela OMS como o processo de otimização das oportunidades de saúde, participação e segurança, com o objetivo de melhorar a qualidade de vida à medida que as pessoas envelhecem, considerando a saúde mental, física e a questão da participação social. Assim, a criação de estratégias que proporcionem acessibilidade, mobilidade e uma melhor qualidade de vida aos idosos é fundamental.

\subsubsection{O idoso e a comunicação digital}

A tecnologia digital permite que os idosos alcancem mais autonomia à medida que as redes sociais permitem a aproximação dos laços sociais, entretenimento; o e-commerce promove o acesso aos produtos e os sites possibilitam o contato com os mais diversos lugares e as mais variadas empresas (OÑATE et al., 2015; BARROSO et al., 2015). Juncos et al. (2006), afirmam que o uso de tecnologias de comunicação por idosos leva a grandes possibilidades de intervenção. Agudo et al. (2012), apontam que as TIC (tecnologias de informação e comunicação) permitem o desenvolvimento cognitivo 
relacionado a linguagem, atenção, memória e raciocínio. Além disso, permitem interatividade e feedback, oferecem segurança aos usuários devido à sua consistência e muitas possibilidades de expansão por meio da sua versatilidade, permitindo aos usuários desfrutar de uma ampla variedade de estímulos visuais e auditivos. Percebe-se, assim, que o acesso à inovação, a ampliação da inclusão social do idoso, o favorecimento da conexão traz a aproximação dos idosos aos novos sujeitos e fenômenos que surgem na sociedade.

Oñate et al. (2015), afirmam que apesar das grandes possibilidades que a comunicação digital pode fornecer, existem muitas barreiras quando ela é utilizada pelos idosos. Os autores afirmam que o recente aumento e desenvolvimento de novas tecnologias não tem permitido um contato contínuo com este grupo. Assim, os idosos apontam a ausência de familiaridade com as tecnologias, não estão preparados para as tecnologias e não recebem treinamento para tal.

Por esse motivo, Agudo et al. (2012) apontam que a forma como o processo de educação é realizada é crucial para incorporar os idosos na cultura digital. Neste sentido, Huelves (2009) indica alguns elementos que precisam ser considerados quando se está desenvolvendo competências digitais nos idosos: memória; psicomotricidade - que é a integração das funções motoras e psíquicas em consequência da maturidade do sistema nervoso -, considerando algumas diretrizes sobre a ergonomia da postura em relação à máquina; desenvolvimento da aprendizagem, demonstrando paciência e compreensão.

Apesar das barreiras da tecnologia para os idosos, percebe-se que muitos idosos estão se conectando à internet. De acordo com a Comscore, cada idoso que usa a internet gastou em média 586 minutos na rede social, o que equivale a 19 minutos por dia. Um estudo desenvolvido pela Nielsen (2014) aponta que os idosos estão despendendo mais tempo na internet do que os jovens: 


\section{Tabela 4 - Tempo de uso da internet}

\begin{tabular}{|c|c|c|c|c|c|}
\hline & $\begin{array}{c}\text { usuários } \\
\text { ativos (000) }\end{array}$ & $\begin{array}{c}\text { distribuição } \\
(\%)\end{array}$ & $\begin{array}{c}\text { sessões por } \\
\text { pessoa }\end{array}$ & $\begin{array}{c}\text { tempo de } \\
\text { computador } \\
\text { por pessoa }\end{array}$ & $\begin{array}{c}\text { páginas vistas } \\
\text { por pessoa }\end{array}$ \\
\hline total & 46.696 & 100 & 32 & $38: 11: 00$ & 1.272 \\
\hline masculino & 24.255 & 51,9 & 35 & $42: 29: 53$ & 1.376 \\
\hline feminino & 22.441 & 48,1 & 28 & $33: 31: 12$ & 1.159 \\
\hline $2-11$ & 6.291 & 13,5 & 15 & $20: 16: 17$ & 499 \\
\hline $12-17$ & 5.529 & 11,8 & 20 & $30: 30: 19$ & 1.120 \\
\hline $18-24$ & 5.821 & 12,5 & 29 & $36: 48: 46$ & 1.357 \\
\hline $25-34$ & 9.763 & 20,9 & 36 & $41: 58: 25$ & 1.530 \\
\hline $35-49$ & 11.678 & 25,0 & 36 & $42: 44: 25$ & 1.408 \\
\hline $50+$ & 7.614 & 16,3 & 44 & $47: 45: 21$ & 1.418 \\
\hline
\end{tabular}

\begin{tabular}{|c|c|c|c|c|c|}
\hline $50-64$ & 6.490 & 13,9 & 44 & $48: 39: 04$ & 1.468 \\
\hline $55+$ & 4.901 & 10,5 & 47 & $50: 46: 32$ & 1.414 \\
\hline $55-64$ & 3.777 & 8,1 & 48 & $53: 12: 53$ & 1.498 \\
\hline $65+$ & 1.124 & 2,4 & 43 & $42: 35: 04$ & 1.127 \\
\hline
\end{tabular}

Fonte: Nielsen, Ibope (2014)

O tempo de uso do computador domiciliar com internet já é maior entre os idosos brasileiros do que entre os jovens, indica a pesquisa NetView, da Nielsen IBOPE (2014), joint-venture entre Nielsen e IBOPE, líder mundial em mensuração do comportamento dos usuários de internet. Segundo o levantamento, pessoas da faixa de 55 a 64 anos de idade foram ao computador em média 48 vezes no mês e os jovens de 12 a 17 anos 20 vezes. Aquele grupo ainda registrou um média individual de tempo de 53 horas e 12 minutos no mês, enquanto o tempo médio de computador domiciliar de um jovem de 12 a 17 anos foi de 30 horas e 30 minutos. A faixa de 55 até 64 anos consome mais de 53 horas por mês de computador, enquanto jovens de 12 a 17 utilizam cerca de 30 horas. Ainda de acordo com o estudo, o grupo de 55 a 64 anos representa 8,1\% do total de 46,7 milhões de usuários ativos domiciliares.

A sociedade abriu espaços para que os idosos se tornem alfabetizados digitalmente e para que eles (embora ainda não muitos) abordem as TIC com a intenção principal de aprender como funcionam e adquiram as competências básicas necessárias para a sua gestão e utilização (Agudo et al., 2012).

Ala-Mutka et al. (2008), sugerem diversas políticas com um enfoque holístico, visando a melhoria da qualidade de vida dos idosos por meio de um processo de formação 
permanente, baseado nas TIC's, no qual o envolvimento das instituições e das gerações mais jovens é essencial. Esses são aspectos cruciais para que se diminua a divisão digital.

Divisão social entre os diferentes países e internamente desses é um claro exemplo que traz consequências como a divisão digital, que é o termo usado para expressar a ideia de que o acesso às comunicações e tecnologias é desigual. A divisão social quantifica a diferença entre os países, setores e pessoas que têm ou não acesso aos instrumentos e ferramentas de informação e à capacidade de usá-los. Trata-se de um termo abrangente com diferenças segundo o contexto em que é analisado (econômico, social, tecnológico, etc.), mas com a mesma intenção: explicar por que alguns países, pessoas ou grupos têm acesso às tecnologias de informação e comunicação (TIC's), enquanto outras não (AGUDO et al., 2012).

Alerta em relação aos perigos das TIC's sem uma inovação e adaptação social paralela, o governo federal criou em 2014 os Telecentros - sob a supervisão do ministério da ciência, tecnologia, inovações e comunicações - para capacitação do idoso no uso das tecnologias da informação e comunicação. Com a finalidade de melhorar a qualidade de vida e aumentar a rede de relacionamento dos idosos, o governo do Estado de São Paulo desenvolveu um programa de inclusão digital que abrange a região metropolitana e o interior, fornecendo treinamento para os idosos já que existe uma gap entre a educação digital e os idosos.

O caráter multidimensional que define a divisão digital aponta que esse é um fenômeno que não deve ser rápido e fácil de resolver. No entanto, não há absolutamente nenhuma dúvida sobre a necessidade de reduzir essas diferenças em favor de uma sociedade para todos, especialmente os idosos.

Apesar das dificuldades de acesso e de aprendizagem, pode-se perceber pelos estudos de Oñate et al., 2015; Barroso et al., 2015 e Juncos et al. 2006, que os aspectos sociais, assim como a comunicação, têm sido identificados como importantes no envelhecimento ativo. Cada vez mais os idosos estão mais interessados na internet, nos dispositivos tecnológicos, e estes estão fazendo parte das suas vidas à medida em que eles descobrem as possibilidades oferecidas (BARROSO et al., 2015). Nishijima et al. (2017), em seu estudo aponta que a divisão digital entre os indivíduos está diminuindo bastante rápido entre os brasileiros ao longo do tempo. No entanto, há margem para políticas de acesso em massa a bens de TIC com base no acesso de banda larga à internet móvel. 
Percebe-se assim que a internet é uma oportunidade para novas descobertas a qual facilita a comunicação e a atividade cognitiva para os idosos, que por consequência contribui para sua autonomia e satisfaz sua demanda por espaço e voz social.

Em um mundo conectado, o envelhecimento ativo pode ser favorecido pelo uso de redes sociais (WEF, 2011). Para Peral et al. (2015), a pesquisa sobre este assunto ainda não foi completamente desenvolvida. A análise dos diferentes comportamentos encontrados na internet é positiva para as empresas.

Pesquisas anteriores descobriram que os usuários da internet podem ser comportamentalmente diferentes dos compradores online e que o uso frequente da internet não se traduz necessariamente em compras online frequentes (Weiser, 2001). Para analisar isso, Weiser (2001) propôs uma classificação entre dois tipos de uso da internet: Socio-Afetivo-Regulamento (SAR) e Aquisição de Bens e Informações (GIA). De acordo com o autor, SAR refere-se ao uso da internet para interagir com outros indivíduos. Já o GIA refere-se ao uso da internet como uma maneira de simplificar o conhecimento e a coleta de informações, bem como para a aquisição de bens e serviços. Ao fazer essa distinção, Weiser (2001) indica que os motivos por trás do uso da internet podem ser amplamente classificados como informativo ou social.

Com base nestas declarações, Esteves et al. (2015) propuseram um modelo que permite compreender o uso da internet pelos consumidores e os impactos de tal uso como intenção de compra, positivo e negativo WOM para as pessoas que estão próximas desses consumidores.

\section{Figura 5 - Propósito no uso da internet}

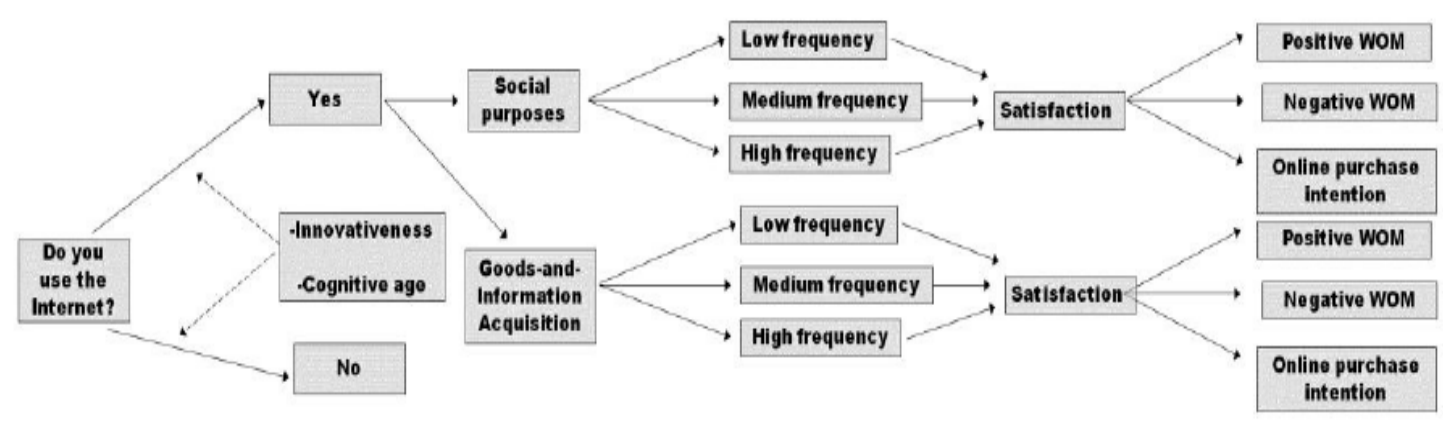

Fonte: Esteves et al. (2015) 
O modelo permite uma melhor compreensão do uso da internet pelos consumidores e os impactos futuros de tal uso. O modelo pode ser aplicado em diferentes faixas etárias, permitindo comparar seus comportamentos diferentes em relação à internet. Assim, declarações sobre as diferentes formas pelas quais as pessoas idosas se comportam na internet podem, assim, ser feitas com uma base teórica e empírica do que era anteriormente, dado que nenhum estudo prévio sabe ter tomado esse tipo de abordagem e incluiu todas as variáveis acima.

Outros trabalhos sobre o comportamento do idoso na internet foram desenvolvidos. Fritsch et al. (2013), em sua revisão bibliográfica, encontraram apenas oito artigos com foco em pessoas com mais de 50 anos e redes sociais. A maioria dessas obras estão centradas na segurança e nos principais obstáculos ao seu uso. Outros, tais como Pfeil et al. (2009), analisam as relações construídas em redes sociais com base na idade. Em seu estudo, Curran e Lennon (2013), consideram a influência das variáveis sociológicas como influência social sobre a intenção de usar as redes sociais entre os idosos. Em 2015 Peral et al. (2015), trazem um estudo que apontam não só variáveis sócio demográficas, mas também variáveis psicológicas dos usuários e não usuários de redes sociais. Finalmente, Lüders e Brandtzæg (2017), retomam assuntos mais amplamente discutidos relacionados às barreiras ao uso da tecnologia e redes sociais.

Percebe-se que apesar das dificuldades apresentadas para o acesso dos idosos ao mundo digital, o aumento deste segmento nas mídias digitais é reconhecido. Peral et al. (2015), afirmam que os idosos mais confiantes com relação ao uso das tecnologias são aqueles que mais usam as redes sociais, a interação social que os idosos alcançam quando participam de redes sociais os mantem em comunicação ativa e aprendendo constantemente.

Assim, uma premissa é apresentada:

Premissa 6: A motivação para o compartilhamento de mensagem se dá devido a necessidade de interação digital, social e aprendizado constante.

\subsubsection{O idoso e as motivações para a comunicação digital}

O acesso à inovação e às novas tecnologias é essencial para evitar o distanciamento das gerações e para que os idosos não se sintam afastados do mundo de hoje. 
Em seu estudo, Lüders e Brandtzaeq (2017), apontam as percepções de idosos nãousuários de redes sociais, investigado as razões e motivações para não ser usuário da mídia digital, verificando se é uma escolha fundamentada. Descobriu-se que o não uso ocorre devido as barreiras como a baixa competência digital e as potenciais consequências da não utilização para experiências de inclusão e exclusão social. O que, apesar de vagaroso, vem sendo modificado tendo em vista que as pessoas pertencem a uma sociedade em que as esferas sociais online e offline estão intimamente envolvidas.

Apesar do isolamento digital sofrido pelo idoso, a divisão digital que maciçamente acontecia, vem sendo cada vez mais assolada com a aplicação das TIC's. Os benefícios trazidos pela adoção das TIC's são apontados em diversas pesquisas (AGUDO et al., 2012; Ala-Mutka et al., 2008), há a sua inclusão social, os idosos são incluídos aos novos sujeitos e fenômenos sociais (AGUDO et al., 2012).

De acordo com Esteves et al. (2015), os idosos começaram a mostrar um maior interesse pelas novas tecnologias, um estudo realizado no Brasil (CGI, 2009), a frequência de uso entre consumidores mais antigos que acessam a internet é como segue: $47 \%$ ao dia, $29 \%$ pelo menos uma vez por semana, $17 \%$ pelo menos uma vez por mês e $7 \%$ menos que uma vez por mês.

Para Barroso et al. (2015), a comunicação digital facilita a interação social, que integra o idoso em relacionamentos que fortalecem suas qualidades sociais e os mantêm fora do perigo do isolamento. Com isso, o idoso fica motivado e satisfeito.

De acordo com Juncos et al. (2006), no processo de envelhecimento normal o acesso a computadores e a internet pode contribuir para o desenvolvimento de novos laços sociais, novas formas de comunicação, novos olhares, acesso à cultura e educação e atividades de estimulação cognitiva. Complementarmente, pode-se perceber que a interação social dos idosos com seus pares e familiares é o que essencialmente garante o envelhecimento ativo, pois tem possibilidades de otimizar a qualidade de vida de muitos tipos de idosos em sua dimensão psicológica e também em uma perspectiva holística (AGUDO et al., 2012; Barroso et al., 2015).

Em seu estudo, Hasan e Linger (2016), a partir da análise de dados indutivos, sugeriram que a utilização das TIC's digitais, ou seja, da internet e a comunicação digital, contribuem positivamente para o bem-estar dos idosos, apontando assim, itens que ganham destaque como: conexão com familiares e amigos, autoestima/desenvolvimento pessoal - fazer parte do mundo digital -, produtividade, ocupação, autossuficiência - não precisar mais de ajuda para algumas tarefas -, estar no controle e prazer/diversão. Com 
esse estudo percebe-se que são muitas as motivações apontadas para a comunicação digital.

\subsection{Interseção entre comunicação boca a boca, internet e o idoso}

Os capítulos anteriores exploraram os constructos comunicação boca a boca, idoso, internet, e colaboraram com o desenvolvimento de insigths para a elaboração do roteiro de entrevistas. Este capítulo cruza esses tópicos, relacionando os assuntos relevantes desta pesquisa, elencando uma revisão bibliográfica que traz a aplicação da comunicação boca a boca, as motivações dos idosos para a comunicação digital, tendo como pano de fundo a análise da comunicação de marketing.

Nesse capítulo são apresentadas as seguintes interseções: idoso e a comunicação boca a boca em meio digital (2.4.1) e motivações do idoso para comunicação boca a boca em meio digital (2.4.2), cuja utilização corroborou essencialmente com a elaboração do roteiro de entrevistas para a pesquisa empírica.

\subsubsection{Idoso e a comunicação boca a boca em meio digital}

A comunicação boca a boca permite a interação das pessoas, este tipo de comunicação corrobora para a tomada de decisão dos consumidores. Phillips e Sternthal (1977) identificam a perda de contatos sociais como um dos fatores por trás das limitações na tomada de decisão da velhice. Essa informação mostra como a comunicação boca a boca torna-se cada vez mais importante para que o idoso se mantenha socialmente integrado.

Em seu estudo, East et al. (2014), mostram a influência da comunicação boca a boca no processo de compra dos idosos. Apontam que os idosos tendem a ser mais leais a marca em algumas categorias de produto, têm um menor conjunto de considerações, e que eles adiam a compra mais do que os consumidores mais jovens. Os autores afirmam ainda que esse comportamento mais conservador, quando comparado aos jovens, pode surgir por que os idosos são mais isolados socialmente, assim, a influência social relacionada a opções de produtos recebida é menor quando comparado a outros grupos. Deste modo, a comunicação boca a boca é utilizada como um indicador da influência social, ou seja, foi analisado como a ausência da comunicação boca a boca afeta a tomada de decisão de compra dos idosos. O estudo constatou que o recebimento de comunicação 
boca a boca cai entre os idosos devido seu isolamento, e que essa diminuição pode explicar parcialmente a tomada de decisão conservadora.

Tendo isso em vista, surge a seguinte premissa:

Premissa 7: $O$ idoso realiza a comunicação boca a boca motivado pelo desejo de inserir outros idosos socialmente e ajudá-los na tomada de decisão.

\subsubsection{Motivações do idoso para comunicação boca a boca em meio digital}

Percebe-se pela revisão da literatura estabelecida, que desde a sua origem, a aplicação do conceito de comunicação boca a boca tem representado uma oportunidade para as empresas atravessarem barreiras da comunicação tradicional entre emissor e receptor, sendo aquele a empresa e este o consumidor como audiência, para transformar o consumidor em um comunicador ativo, disseminador de mensagens da empresa e da marca.

Esse cenário fez a comunicação se basear em dois princípios básicos: o uso de um sistema de disseminação peer-to-peer (par a par), ou seja, ponto a ponto, em que o consumidor atua também como disseminador; e o oferecimento de conteúdo livre e atraente que mascara seu propósito comercial para o indivíduo. A transformação do espectador passivo em um usuário ativo, que transmite mensagens promovidas por patrocinadores e que responde às necessidades e motivações de características individuais (DAFONTE, 2014).

O segmento dos idosos faz parte desse cenário. À medida que o idoso acessa a tecnologia, se transforma também em um comunicador ativo. Muitos idosos de hoje querem uma aposentadoria ativa, aprendendo novas habilidades (EASTMAN e IYER, 2004). Assim, para que os idosos se juntem à era da informação propriamente, a sociedade, que está cada veze mais tecnológica, deve compreender as barreiras, meios necessários e motivações dos idosos.

Ao analisar o segmento dos idosos do ponto de vista econômico, Trocchia e Janda (2000), afirmam que se trata de um segmento inexplorado, com mais renda e tempo discricionários do que outros segmentos. Do ponto de vista social, McMellon e Schiffaman (2000) perceberam que houve uma melhor qualidade de vida para os idosos que de alguma forma possuíam restrições físicas devido problemas relacionados a idade 
quando estes realizavam a comunicação online. Os autores apontam que as atividades na internet tais como comunicação pessoal, assuntos financeiros, entretenimento e informação, oferecem oportunidades que poderiam ser benéficas para idosos com mobilidade limitada.

Percebe-se que a comunicação boca a boca tem aplicação direta para empresas que desejam atingir um consumidor idoso, que as pessoas percebem como uma boa fonte de informação de mercado, e que gosta de introduzir novas marcas para os outros.

Tendo em vista a lacuna que existe na literatura e as grandes possibilidades para o meio acadêmico e para o meio corporativo, o aprofundamento da pesquisa em comunicação boca a boca em meio digital, a compreensão das motivações para o compartilhamento de mensagem desse segmento faz-se necessária.

Uma ampla revisão da literatura sobre os temas boca a boca, motivação para comunicação e idoso em meio digital tendo como pano de fundo a análise da comunicação de marketing não mostrou nada especificamente sobre as motivações dos idosos para comunicação boca a boca em meio digital. Nesse sentido, essa pesquisa associada às premissas supracitadas podem fornecer subsídios para a área acadêmica, para área de marketing e para as empresas de um modo geral.

\section{MÉTODO DA PESQUISA EMPÍRICA}

\subsection{Método}

O trabalho tem caráter exploratório e abordagem qualitativa. Para a coleta de dados, optou-se pela entrevista em profundidade, utilizando-se um roteiro semiestruturado de perguntas para as entrevistas. As entrevistas serão aplicadas em idosos usuários da internet da região do sudeste de São Paulo, pois com base na pesquisa do Instituto Brasileiro de Opinião Pública e Estatística (IBOPE, 2015), a região mais conectada do país é o Sudeste, que concentra $49 \%$ das pessoas que acessam a internet.

A análise de dados foi conduzida segundo os postulados da análise de conteúdo. $\mathrm{O}$ presente estudo está organizado em sete partes. A introdução na primeira parte, a segunda parte contempla o referencial teórico sobre os temas centrais. Em seguida, o método do estudo é detalhado, os dados são analisados. Posteriormente o estudo trás as 
considerações finais, limitações da pesquisa e sugestões para estudos futuros, e referências.

\subsection{Definições do caráter, abordagem e procedimentos metodológicos de campo}

A pesquisa tem caráter exploratório e abordagem qualitativa. A pesquisa qualitativa visa explicar determinados fatos e o objetivo dos respondentes é produzir informações, seja essa pequena ou grande, a sua importância está na capacidade de gerar conhecimento. Richardson (2007) explica que o uso do método qualitativo está voltado para a busca de significados e dados subjetivos. Para Gerhardt e Silveira (2009), a pesquisa qualitativa preocupa-se com aspectos da realidade que não podem ser quantificados, centrando-se na compreensão e explicação da dinâmica das relações sociais. Complementarmente, Flick (2009) afirma que a pesquisa qualitativa visa abordar o mundo externo, sem focar em contextos especializados de pesquisa como os laboratórios, buscando entender, descrever, explicar fenômenos sociais, utilizando-se da análise das experiências de indivíduos e grupos, examinando interações e comunicações que estejam se desenvolvendo e investigando documentos ou traços semelhantes de experiências ou interações.

Já a pesquisa exploratória, de acordo com Köche (2004), é indicada quando existe a intenção de levantar possíveis itens sobre o fenômeno que se quer estudar, o que de fato estabelece o objetivo desse estudo. Gil (2007, p.43) afirma:

Pesquisa exploratória tem como finalidade desenvolver, esclarecer ou modificar conceitos e ideias, tendo em vista, a formulação de problemas mais precisos ou hipóteses pesquisáveis para estudos posteriores.

Tal afirmação confirma a característica desta pesquisa. Quanto aos procedimentos, a pesquisa está dividida em duas etapas: primeiramente foi realizado um levantamento bibliográfico, a partir da pesquisa das referências teóricas dos conceitos de comunicação de marketing/boca a boca, internet e idosos.

Com base no modelo de Ho e Dempsey (2010), foram identificadas quatro motivações potenciais para a comunicação boca a boca. Em seguida foi realizada uma pesquisa de campo, por meio de entrevistas em profundidade com usuários idosos da internet e da observação do compartilhamento de mensagens na rede social Facebook dos entrevistados. 
A triangulação de dados, de acordo com Flick (2009), é a combinação de métodos no estudo do mesmo fenômeno, que colabora com a validação do estudo e a coleta de mais conhecimento. Assim, o entrevistador diminui a influência do seu viés no estudo, e maximiza a validade dos esforços de campo (DENZIN, 1970).

\subsection{Planejamento das informações}

O estudo é transversal, ou seja, será realizado em uma única vez e com a representação de um determinado momento. $\mathrm{O}$ ambiente da pesquisa se dá sob condições reais, pois serão entrevistados pessoalmente usuários idosos da internet e seus compartilhamentos de mensagens nas páginas da rede social Facebook serão observadas durante a entrevista em profundidade.

\subsubsection{Definição dos respondentes}

As entrevistas em profundidade em pesquisas qualitativas não seguem os critérios de representatividade estatísticas, amostragem sociodemográfica (GODOI; MATTOS, 2006). A definição dos respondentes, de acordo com Godoi e Mattos (2006) deve seguir o critério do ponto de saturação ou redundância, em que a medida que o pesquisador encontre repetição, similaridades nas respostas dos entrevistados, perceba que dados adicionais não são mais adquiridos para a contribuição do estudo e da construção das propriedades categóricas. Assim, propõem-se para essa pesquisa entrevistar respondentes idosos usuários da internet até que o objetivo da pesquisa seja atingido.

Caracteriza-se como idoso, de acordo com a Organização Mundial da Saúde (OMS), aquele que tem 60 anos de idade ou mais.

Os respondentes serão escolhidos por conveniência, baseada nos critérios abaixo, num primeiro instante, e outros respondentes poderão ser indicados pelos participantes da pesquisa, num processo conhecido como "bola de neve" (ZIKMUND, 2006).

Os respondentes idosos usuários de internet foram escolhidos com base na pesquisa do Instituto Brasileiro de Opinião Pública e Estatística (IBOPE, 2015), que informa que a região mais conectada do país é o Sudeste, que concentra $49 \%$ dos que acessam a internet. Também foi adotado como critério a escolha por respondentes que realizavam a 
comunicação boca a boca no meio digital de alguma forma como a utilização do aplicativo "WhatsApp", redes sociais, especificamente o Facebook, para que as observações sejam feitas no mesmo ambiente virtual para todos os respondentes.

\subsection{Método de coleta de dados no campo}

Para Lakatos e Marconi (1989), o método de coleta de dados é um conjunto de atividades sistemáticas e racionais que, permitem o pesquisador alcançar o objetivo do seu estudo com maior segurança e economia, traçando o caminho a ser seguido.

Para realização desse estudo, será utilizada a entrevista em profundidade e observação do compartilhamento de mensagens no Facebook. De acordo com Roesch (1999), a entrevista é um método fundamental para pesquisas qualitativas porque permite abordar temas complexos em profundidade que dificilmente seriam investigados adequadamente por meio de questionário. Já a observação reúne não só as percepções visuais, mas também as baseadas na audição, no tato e no olfato, de modo que seja explicado, compreendido e descrito os eventos e comportamentos observados pelo pesquisador (ADLER E ADLER, 1998; FLICK, 2004; VERGARA, 2012). Vergara (2012), afirma que é preciso ter cuidado não só no planejamento do que e por que observar, quanto ao próprio cuidado do observador em manter certo distanciamento que, mesmo na interação com seus observados, lhe permita neutralizar tendenciosidades epistemológicas ou valorativas.

Quanto ao tipo de observação, será adotado o observador participante. Para Creswell (2010) são quatro os tipos de observação: participação completa, em que o pesquisador não se revela como observador; observador participante, quando o papel do observador é conhecido; participante como observador, em que o papel do observador é secundário; e observador completo, quando o observador observa sem participar.

Serão seguidos os critérios de observação estruturada, em que os objetivos e propósitos são predefinidos. Assim, a observação poderá ajudar a clarificar comportamentos em termos de frequência, duração, forma, sequenciamento de ocorrências, na medida em que o observador decodifique o que está observando (VERGARA, 2012).

No que se refere o propósito de utilizar a entrevista em profundidade como método de coleta de dados na pesquisa qualitativa em administração, percebe-se que são explorados os pontos de vista, experiências, crenças e/ou motivações dos indivíduos sobre 
questões específicas no campo organizacional, atendendo principalmente a finalidades exploratórias, ao abordar experiências e pontos de vistas dos atores inseridos nestes contextos (OLIVEIRA et al., 2012).

Godoi e Mattos (2006), conceituam os três tipos de entrevistas: conversacional livre, padronizada aberta e baseada em roteiro. A conversacional livre é baseada em um tema, com perguntas dentro do contexto estabelecido e no curso natural à interação, sem que haja previsões de perguntas e respostas. Já a entrevista padronizada aberta possui uma lista de perguntas ordenadas e redigida por igual a todos entrevistados, mas com respostas abertas. A entrevista baseada em roteiro tem a preparação desse roteiro prévio à entrevista, mas o entrevistador possui flexibilidade para ordenar e formular perguntas durante a entrevista. É o mesmo conceito atribuído por Gill et al. (2008), nomeado como não estruturada, estruturada e semiestruturada, respectivamente.

Nesse estudo, as entrevistas serão por roteiro semiestruturado, em que os propósitos do estudo estão claros para os entrevistados, mas sem perguntas e respostas predefinidas, tendo seu objetivo atingido quando as respostas dos entrevistados são espontâneas, específicas e concretas (SELLTIZ et al., 1975). Os autores afirmam ainda que a flexibilidade da entrevista em profundidade pode acarretar em dificuldades de comparabilidade entre as respostas dos entrevistados. Para evitar esse tipo de complicação na análise dos resultados, elaborou-se um roteiro de entrevistas fundamentado na revisão da literatura, que será seguido em todas entrevistas. O roteiro encontra-se no capítulo intitulado "apêndice".

Conforme orientado por Richardson (2007), o roteiro passou por um pré-teste para que se pudesse corrigir aspectos da investigação. O pré-teste compreende a aplicação prévia do instrumento de coleta de dados a especialistas, pessoas que possuam profundos conhecimentos na área de estudo da pesquisa ou intimidade com o público-alvo da pesquisa. Nesse estudo, o pré-teste foi realizado com três pessoas idosas usuárias de internet.

O roteiro de entrevista dos usuários da internet idosos está estabelecido da seguinte maneira:
1) Confirmação do filtro do respondente;
2) Entrevista;
3) Perfil dos respondentes. 
No item "1" é verificado se o entrevistado tem 60 anos, se realiza a comunicação boca a boca pelo Facebook. A entrevista tratada no item "2" se inicia com perguntas sobre o comportamento do entrevistado com o boca a boca em meio digital com a intenção de iniciar a conversação e "quebrar o gelo" (FLICK, 2004), direcionando para o tema central da pesquisa. Nesse item foram estabelecidas perguntas baseadas no referencial teórico que estabelecem as categorias definidas a priori (Flick, 2004). O item “3”, de menor importância para esse estudo, por esse motivo está estrategicamente como último item do roteiro, serve para organização dos dados da pesquisadora.

Foi estabelecida pelo menos uma pergunta no roteiro semiestruturado para cada item relacionado na revisão da literatura sobre a motivação para a comunicação boca a boca, conforme estabelecido abaixo:

Tabela 5 - Definições para o roteiro de pesquisa

\begin{tabular}{|c|c|c|c|}
\hline Item analisado & Subitens & Perguntas & $\begin{array}{c}\text { Referência } \\
\text { bibliográfica }\end{array}$ \\
\hline \multirow[t]{3}{*}{$\begin{array}{l}\text { A necessidade de } \\
\text { fazer parte de um } \\
\text { grupo } \\
\end{array}$} & Ser identificável & $\begin{array}{l}\text { Seus compartilhamentos identificam seu } \\
\text { modo ser pensar e agir? }\end{array}$ & \multirow{3}{*}{$\begin{array}{c}\text { Ho e Dempsey, } \\
\text { (2010); Schutz, } \\
\text { (1966); Tang et al., } \\
\text { (2016) }\end{array}$} \\
\hline & $\begin{array}{l}\text { Reconhecimento como } \\
\text { participante em uma } \\
\text { ação }\end{array}$ & $\begin{array}{l}\text { Você é reconhecido como pertencente a } \\
\text { alguma ação ao realizar o boca a boca? }\end{array}$ & \\
\hline & $\begin{array}{l}\text { Pertencer, unir-se, } \\
\text { juntar-se }\end{array}$ & $\begin{array}{l}\text { Você acredita que compartilhar conteúdos } \\
\text { com outras pessoas faz com que outras } \\
\text { pessoas te aceitem? Isso é importante para } \\
\text { você? Por quê? }\end{array}$ & \\
\hline \multirow[t]{3}{*}{$\begin{array}{c}\text { A necessidade de } \\
\text { marcar a } \\
\text { individualidade }\end{array}$} & $\begin{array}{l}\text { Compartilhamento de } \\
\text { coisas relacionadas a } \\
\text { autoimagem }\end{array}$ & $\begin{array}{l}\text { Você compartilha coisas relacionadas a sua } \\
\text { autoimagem? }\end{array}$ & \multirow{3}{*}{$\begin{array}{l}\text { Ho e Dempsey, } \\
\text { (2010); Chung e } \\
\text { Darke, (2006); } \\
\text { Sundaram et al., } \\
\text { (1998); Dichter, } \\
\text { (1966); Chan e Misra, } \\
\text { (1990) }\end{array}$} \\
\hline & $\begin{array}{c}\text { Ganhar status e } \\
\text { atenção }\end{array}$ & $\begin{array}{c}\text { Se você pudesse se destacar com algum } \\
\text { compartilhamento você acredita que isso lhe } \\
\text { faria compartilhar mais do que você já } \\
\text { compartilha? }\end{array}$ & \\
\hline & $\begin{array}{l}\text { Se diferenciar dos } \\
\text { outros }\end{array}$ & $\begin{array}{c}\text { Você acredita que seus compartilhamentos } \\
\text { destacam você dos outros usuários da } \\
\text { internet? }\end{array}$ & \\
\hline $\begin{array}{l}\text { A necessidade de } \\
\text { ser altruísta }\end{array}$ & $\begin{array}{l}\text { Manter-se em um } \\
\text { relacionamento } \\
\text { satisfatório }\end{array}$ & $\begin{array}{l}\text { Você acredita que seus compartilhamentos } \\
\text { promovem acolhimento ou envolvimento } \\
\text { emocional? }\end{array}$ & $\begin{array}{c}\text { Ho e Dempsey, } \\
\text { (2010); Schutz, } \\
\text { (1966); Price et al., } \\
\text { (1995) }\end{array}$ \\
\hline
\end{tabular}




\begin{tabular}{|c|c|c|c|}
\hline & $\begin{array}{l}\text { Relacionamentos que } \\
\text { levem a } \\
\text { comportamentos } \\
\text { relacionados à } \\
\text { intimidade, } \\
\text { acolhimento, } \\
\text { envolvimento } \\
\text { emocional }\end{array}$ & & $\begin{array}{l}\text { Ho e Dempsey, 2010; } \\
\text { Schutz, 1966; Price et } \\
\text { al., } 1995\end{array}$ \\
\hline & Altruísmo & $\begin{array}{l}\text { Você compartilha conteúdo na internet para } \\
\text { ajudar outras pessoas? }\end{array}$ & $\begin{array}{c}\text { Dichter (1966); Phelps } \\
\text { et al., (2004); } \\
\text { Sundaram et al., } \\
\text { (1998); Hennig- } \\
\text { Thurau et al., (2004) }\end{array}$ \\
\hline \multirow[t]{3}{*}{$\begin{array}{l}\text { A necessidade de } \\
\text { crescimento } \\
\text { pessoal }\end{array}$} & $\begin{array}{c}\text { Sentimento de } \\
\text { competência, } \\
\text { influência, realização }\end{array}$ & $\begin{array}{c}\text { Você acredita que seu compartilhamento irá } \\
\text { ajudar você a alcançar seus objetivos } \\
\text { pessoais? }\end{array}$ & \multirow{3}{*}{$\begin{array}{c}\text { Ho e Dempsey, } \\
\text { (2010); Schutz, (1966) }\end{array}$} \\
\hline & $\begin{array}{c}\text { Fazer a diferença em } \\
\text { seu ambiente social e } \\
\text { dizer como isso } \\
\text { acontece }\end{array}$ & $\begin{array}{l}\text { Seu compartilhamento mostra que você faz a } \\
\text { diferença em seu ambiente social? }\end{array}$ & \\
\hline & $\begin{array}{l}\text { Compartilha como meio } \\
\text { de desenvolvimento de } \\
\text { conhecimento ou } \\
\text { experiência, motivado } \\
\text { pelo sentimento de } \\
\text { crescimento pessoal }\end{array}$ & $\begin{array}{l}\text { Você acredita que o compartilhamento pode } \\
\text { ajudá-lo no seu crescimento pessoal? }\end{array}$ & \\
\hline \multirow[t]{2}{*}{$\begin{array}{c}\text { Relação do cliente } \\
\text { com a empresa }\end{array}$} & $\begin{array}{c}\text { Gera boca a boca } \\
\text { positivo quando há } \\
\text { satisfação com a marca }\end{array}$ & \multirow{2}{*}{$\begin{array}{c}\text { A sua relação com a empresa te motiva a } \\
\text { compartilhar conteúdos positivos ou } \\
\text { negativos? }\end{array}$} & $\begin{array}{l}\text { Oliver, (1980); Swan e } \\
\text { Oliver, (1989) }\end{array}$ \\
\hline & $\begin{array}{c}\text { Gera boca a boca } \\
\text { negativo quando há } \\
\text { insatisfação com a } \\
\text { marca }\end{array}$ & & Esteves et al., (2015) \\
\hline $\begin{array}{l}\text { A necessidade de } \\
\text { interação digital, } \\
\text { social e o } \\
\text { aprendizado } \\
\text { constante } \\
\end{array}$ & $\begin{array}{l}\text { Manter-se em } \\
\text { comunicação ativa e } \\
\text { aprender } \\
\text { constantemente }\end{array}$ & $\begin{array}{l}\text { Manter-se em comunicação ativa e aprender } \\
\text { constantemente é uma motivação para que } \\
\text { você realize a comunicação boca a boca? }\end{array}$ & $\begin{array}{l}\text { Peral et al., (2015); } \\
\text { East et al., (2014) }\end{array}$ \\
\hline \multirow[t]{2}{*}{$\begin{array}{l}\text { A necessidade de } \\
\text { inserir outros } \\
\text { idosos } \\
\text { socialmente e } \\
\text { ajudá-los na } \\
\text { tomada de } \\
\text { decisão }\end{array}$} & $\begin{array}{l}\text { Diminuição do } \\
\text { isolamento digital e } \\
\text { apoio à tomada de } \\
\text { decisão }\end{array}$ & \multirow[t]{2}{*}{$\begin{array}{c}\text { Seu compartilhamento pode causar a } \\
\text { diminuição do isolamento digital e apoio à } \\
\text { tomada de decisão dos idosos que você } \\
\text { conhece? }\end{array}$} & $\begin{array}{l}\text { Phillips e Sternthal } \\
\text { (1977); East et al., } \\
\text { (2014) }\end{array}$ \\
\hline & $\begin{array}{c}\text { Diminuição do } \\
\text { isolamento digital e } \\
\text { apoio à tomada de } \\
\text { decisão do remetente }\end{array}$ & & $\begin{array}{l}\text { East et al., (2014); } \\
\text { Arndt, (1967); } \\
\text { Labsomboonsiri et } \\
\text { al. (2017) }\end{array}$ \\
\hline
\end{tabular}




\begin{tabular}{|c|c|c|c|} 
& & & \\
\hline \multirow{2}{*}{ Outros } & $\begin{array}{c}\text { Informações úteis } \\
\text { contidas na mensagem }\end{array}$ & $\begin{array}{c}\text { Questões como informações úteis contidas na } \\
\text { mensagem e recompensa econômica podem } \\
\text { motivar você a realizar a comunicação boca a a } \\
\text { boca? }\end{array}$ & $\begin{array}{c}\text { Berger e Milkman } \\
\text { (2012); Kasabov } \\
(2016) ; \text { Sundaram et } \\
\text { al. (1998) }\end{array}$ \\
\cline { 4 - 5 } & $\begin{array}{c}\text { Incentivos, recompensa } \\
\text { econômica, } \\
\text { reciprocidade }\end{array}$ & $\begin{array}{c}\text { Tang et al., (2016); } \\
\text { Bentivegna, (2002) }\end{array}$ \\
\hline
\end{tabular}

Fonte: elaborado pela autora

No que se refere a validação dos dados da entrevista, as afirmações de validade feitas por alguém que fala em uma entrevista devem ser diferenciadas, ou seja, julgadas separadamente. Segundo Legewie (1987 p. 141 apud Flick, 2009):

Que o conteúdo do que se disse esteja correto, [...] que o que se disse seja socialmente importante em seu aspecto relacional [...] e [...] que o que se disse seja sincero em termos de auto apresentação de quem fala.

Assim, os dados terão validade para o estudo e colaborarão para as análises dos dados e considerações finais.

\subsection{Análise de conteúdo}

Após a realização das entrevistas, a pesquisadora terá a mão os dados primários da transcrição das entrevistas. De acordo com Godoi (2006), o discurso é inerente à vida social, e não deve ser analisado fora desse contexto. Creswell (2010) afirma que a análise de conteúdo consisti em extrair sentido dos dados de texto e imagem. Para Bardin (2007, p. 37), a análise de conteúdo é conceituada como:

Um conjunto de técnicas de análise das comunicações visando obter, por procedimentos sistemáticos e objetivos de descrição do conteúdo das mensagens, indicadores (quantitativos ou não) que permitam a inferência de conhecimentos relativos às condições de produção/recepção (variáveis inferidas) dessas mensagens.

A análise de conteúdo se apoiou em códigos linguísticos retirados da entrevista em profundidade. De acordo com Bardin (2007), a análise de conteúdo começa com a 
descrição das características do texto e termina com a interpretação dessas características, sendo que a inferência é o procedimento intermediário que permite a passagem da primeira à última etapa. Flick (2004), afirma que a interpretação de dados é centro da pesquisa qualitativa. Ela tem a função de desenvolver a teoria, servindo ao mesmo tempo de base para decisão sobre quais dados adicionais devem ser coletados.

A criação de categorias a priori com base no referencial teórico, o uso de um roteiro semiestruturado e a análise sistemática possibilitariam que a realização dos mesmos procedimentos por outros pesquisadores levasse a resultados semelhantes, garantindo assim, os aspectos de confiabilidade na pesquisa empírica qualitativa (FLICK, 2004; MAYRING, 2014). Essa categorização também favorece a observação estruturada, facilitando o processo de organização e decodificação.

Godoi (2006), afirma que a principal ferramenta de investigação é a capacidade interpretativa do investigador porque a análise do discurso é formada por um conjunto de conhecimentos que vêm de diversas disciplinas: "a interpretação é, ao mesmo tempo, um diálogo com o texto e com os outros, daí o cuidado de não se incorrer no oposto da receita técnica, a arbitrariedade interpretativa". Para evitar essa complicação, o método de análise de conteúdo do presente estudo ocorrerá considerando as etapas descritas a seguir.

Cada entrevista selecionada ao acaso será sistematicamente examinada via os passos de análise de conteúdo propostos por Flick (2004) e Mayring (2014). De acordo com os autores, a análise de conteúdo deve seguir as seguintes etapas: 
Figura 6 - Análise de conteúdo

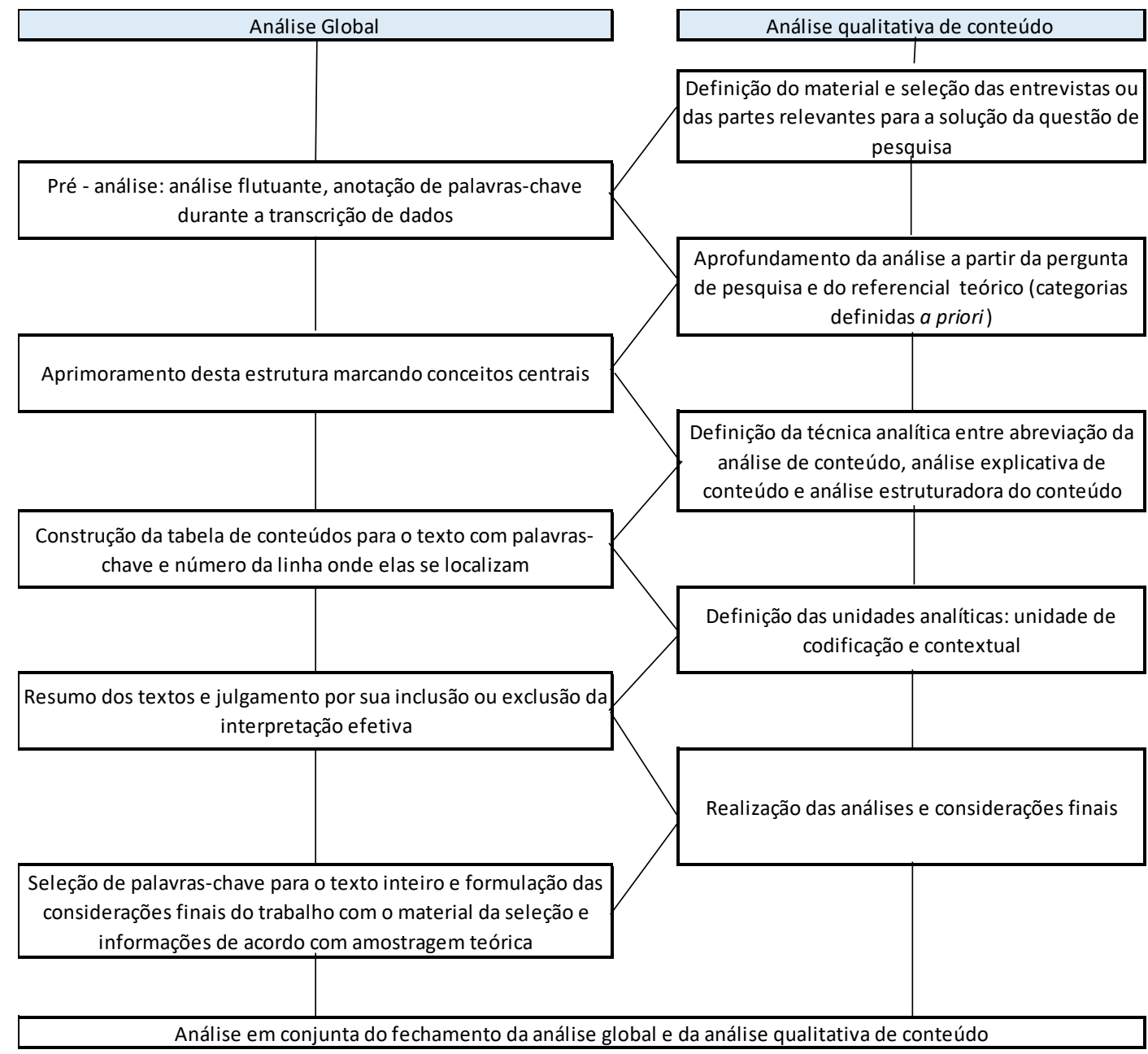

Fonte: elaborado pela autora - baseado em Flick (2004) e Mayring (2014).

A análise de conteúdo é um dos procedimentos clássicos para análise do material textual, uma das suas características essenciais é o emprego de categorias obtidas, com frequência, de modelos teóricos. As categorias são trazidas para o material empírico e não necessariamente desenvolvidas a partir deste, embora sejam avaliadas contrastivamente a esse material, e se necessário, modificadas (FLICK, 2009). A análise global serve como um suplemento com orientação pragmática para a análise de conteúdo (LEGEWIE, 1994 apud FLICK, 2004). Na etapa de pré-análise é realizada uma leitura do texto e palavraschave ao longo da transcrição são anotadas, os trechos extensos são estruturados. Para Bardin (2007), a pré-análise, que engloba a análise flutuante, é a fase de organização, que torna operacional as ideias iniciais e as sistematiza, conduzindo a um esquema do 
desenvolvimento das operações seguintes, num plano de análise. A etapa de pré-análise considerará a leitura flutuante do material, que consiste em estabelecer contato e analisar o texto, com a preocupação de preparar o material de análise em recortes de textos comparáveis, tirando impressões e orientações; o aprimoramento desta estrutura com a marcação dos conceitos centrais, e nela são identificadas as informações sobre a situação comunicativa na geração de cada texto (Legewie, 1994 apud Flick, 2009).

$\mathrm{Na}$ etapa seguinte são aprimoradas as estruturas, marcando conceitos centrais. Logo após é construída uma tabela de conteúdos para o texto, que inclui as palavras-chave estruturadas anteriormente, juntamente com o número das linhas as quais elas se referem. Os temas são postos em ordem alfabética, e as ideias anotadas nas diversas etapas são coletadas em uma lista. A etapa seguinte resume o texto e julga por sua inclusão ou não na interpretação efetiva. Assim, anotam-se as palavras-chave para o texto inteiro e formulam-se as considerações finais (Legewie, 1994 apud Flick, 2009).

A primeira etapa da análise de conteúdo, definição do material, consiste em selecionar as entrevistas ou aquelas partes que sejam relevantes na solução da questão de pesquisa. Na segunda etapa, analisa-se a situação da coleta de dados. Ou seja, como foi produzido o material, quem participou da produção, de onde vêm os documentos analisados. Na terceira etapa há uma caracterização formal do material, mostrando como foi documentado o material, nesse caso com gravação, e como foi editado - influência da transcrição sobre os textos. Na quarta etapa, há a definição da direção da análise para os textos selecionados e o que se espera interpretar com eles. Na etapa seguinte a questão de pesquisa é diferenciada ainda mais, com base nas teorias. Logo após essas etapas, é definida a técnica analítica:

a) Abreviação da análise de conteúdo: o material é parafraseado, trechos menos relevantes que possuam significados iguais são omitidos (primeira redução), e paráfrases semelhantes são condensadas e resumidas (segunda redução).

b) Análise explicativa de conteúdo: esclarece trechos difusos. Utilizase da análise do contexto restrito - apanha enunciados adicionais do texto a fim de explanar os trechos a serem analisados -, e da análise do contexto amplo que busca informações fora do texto (extraídas de teorias, sobre o autor, etc) e com base nisso formula-se a paráfrase. 
c) Análise estruturadora do conteúdo: busca tipos ou estruturas formais no material. Seguindo aspectos formais, consegue-se revelar gradualmente uma estrutura interna (estrutura formal) no material; o material pode ser extraído e consensado a certos domínios de conteúdo (estruturação com relação ao conteúdo). Ainda pode-se buscar aspectos únicos e evidentes no material e explica-los com detalhamento (estruturação responsável pela tipificação). Pode-se classificar o material conforme as dimensões na forma de escalas (estruturação representada por escalas).

Nesse estudo serão considerados na técnica analítica a frase ou a resposta as perguntas abertas do entrevistado.

Por fim, definem-se as unidades analíticas. A unidade analítica define quais passagens são analisadas uma após a outra, e são classificadas assim: unidade contextual (define qual o maior elemento no texto que admite o enquadramento em uma categoria) e unidade de codificação (define qual o menor elemento de material que é possível de analisar e de ser enquadrado em uma categoria). Na penúltima etapa, são feitas as análises efetivas antes que seus resultados sejam interpretados com referência à questão de pesquisa, elaborando-se e respondendo-se a questões de validade (MAYRING, 2014).

Segundo Bardin (2007), a etapa de agregação, que é a categorização das unidades poderá utilizar o critério semântico, que usa categorias temáticas com algum significado; sintático, que são verbos e adjetivos; lexical, que é a classificação da palavra segundo seu sentido; e expressivo, que é o uso de categorias que classificam as diversas expressões da linguagem. Esse trabalho seguirá da seguinte maneira: serão considerados em cada discurso, palavras específicas, e após tratamento, apenas as palavras-chave, que têm relação com o tema desse estudo. A categorização das unidades será por critério semântico, que analisa o tema comum dos elementos de cada variável.

À medida em que cada entrevista for analisada, o construto explicitado e a quantidade de novos construtos e itens adicionadas com uma nova entrevista, serão registradas pela pesquisadora, para que se possa entender quando ocorreu o ponto de saturação do construto e itens em análise. Por esse motivo, a escolha aleatória das entrevistas para análise torna-se essencial. Flick (2009), afirma ainda que a escolha aleatória possibilita a exclusão de qualquer viés de seleção dos respondentes.

A última etapa da análise de conteúdo consiste no tratamento simples dos resultados, permitindo a elaboração de tabelas que condensam e destacam as informações 
fornecidas para análise (BARDIN, 2007). O tratamento dos resultados permite fazer as inferências e interpretações das entrevistas transcritas.

A questão de pesquisa deste estudo será respondida pela análise das etapas do método de coleta - por meio do roteiro semiestruturado em "apêndice" - conforme explicitado na figura seis. A figura seis sintetiza o desenvolvimento da análise de conteúdo proposta nesse estudo.

\subsection{Entrevistas e transcrição de dados}

Para o desenvolvimento da análise de conteúdo é importante que seja considerado o contexto em que a pesquisa foi realizada. Todas as entrevistas foram realizadas no período de vinte e cinco junho até dois de julho de 2017, pessoalmente, em locais sugeridos pelos respondentes, como suas residências, universidades (públicas e particulares). $\mathrm{O}$ agendamento das entrevistas foi feito em média sete dias antes da entrevista propriamente. Cada entrevista durou aproximadamente uma hora, foram realizadas entrevistas até que se pudesse perceber a repetição de dados por parte dos respondentes, gerando no total, a realização de dez entrevistas.

As entrevistas foram gravadas, com a autorização dos respondents, permitindo maior naturalidade e espontaneidade nas respostas dos entrevistados (Flick, 2004). Todos os entrevistados autorizaram a gravação e permitiram que um gravador fosse colocado próximos a eles para a captura do som das suas respostas, ficando ali até que a entrevista fosse encerrada. Durante as entrevistas algumas notas, com elementos essenciais das respostas e informações sobre o andamento da entrevista, foram feitas em um documento em word com a utilização de um notebook pela entrevistadora, com a intenção de facilitar a análise dos dados.

Todo material captado em áudio das entrevistas foi posteriormente transcrito para que os dados fossem analisados. A transcrição foi realizada com o amparo do programa da Google Web Speech, que realiza o reconhecimento da fala e a interpretação das palavras ditas, transcrevendo todo o conteúdo. Com o material transcrito pelo Web Speeh em mãos, todos os áudios foram escutados e assim, o texto da transcrição foi checado. Alguns termos e expressões como "ahm", “ehm”, "humm” foram retirados da transcrição e pequenos ajustes foram realizados por falhas na transcrição da inteligência artificial. Para Flick (2004) não há um padrão estabelecido para a transcrição de dados, é comum o 
interesse em concentrar-se na obtenção do máximo de exatidão ao apresentar enunciados, intervalos, etc, porém uma transcrição de dados excessivamente exata absorve tempo e energia que poderiam ser investidos de forma mais racional na interpretação. 


\section{ANÁLISE QUALITATIVA DE CONTEÚDO DOS DADOS EMPÍRICOS}

Nesse capítulo são apresentadas as análises dos conteúdos dos dados empíricos coletados durante as entrevistas realizadas com idosos usuários da internet. A análise dos dados contempla a análise global e análise qualitativa de conteúdo, realizando logo após o cruzamento desses dados com as informações do referencial teórico. A análise qualitativa de conteúdo será amparada com os itens que foram observados nas páginas dos Facebook dos entrevistados após a realização da entrevista com o roteiro semiestruturado.

\subsection{Análise Global e análise qualitativa de conteúdo}

A análise global corrobora para se obter uma visão geral do espectro temático do texto (FLICK, 2004). Ela serve como complemento que orienta de forma prática outros procedimentos de análise, como a análise qualitativa de conteúdo que está sendo usada nesse estudo.

$\mathrm{Na}$ leitura por meio dos textos advindos das transcrições, anotou-se as palavraschave e estruturou-se os trechos extensos do texto. Na sequência aprimorou-se esse material marcando os conceitos ou enunciados centrais.

Durante a leitura do texto foram anotadas ideias. A essa etapa seguiu-se a produção de uma tabela de conteúdos para o texto, que inclui as palavras-chave estruturadoras anotadas anteriormente, juntamente com os números das linhas as quais essas se referem.

\section{Tabela 6 - Análise global}

\begin{tabular}{|l|l|l|}
\hline \multicolumn{1}{|c|}{ Palavras-chave } & Página & \multicolumn{1}{c|}{ Linhas dos trechos } \\
\hline Aceitação & 15 & $10-11 ; 29-31$ \\
\hline Aceitação & 21 & $3-6$ \\
\hline Aceitação & 24 & $1-7$ \\
\hline Aprendizado & 1 & $7 ; 9-12 ; 17-18 ; 23$ \\
\hline Aprendizado & 8 & $3-6 ; 11-19 ;$ \\
\hline Aprendizado & 12 & $1-2 ; 14 ; 19$ \\
\hline Aprendizado & 11 & $29-34$ \\
\hline Aprendizado & 14 & $5-7 ; 23$ \\
\hline Aprendizado & 18 & $12-19$ \\
\hline
\end{tabular}




\begin{tabular}{|c|c|c|}
\hline Aprendizado & 20 & 15 \\
\hline Aprendizado & 22 & 6 \\
\hline Aprendizado & 23 & $14-17$ \\
\hline Aprendizado & 23 & $32-34$ \\
\hline Aprendizado & 27 & $1-2 ; 7-9$ \\
\hline Atualidade & 12 & $17-18$ \\
\hline Atualidade & 30 & $4-6$ \\
\hline Autoimagem & 9 & $15-17$ \\
\hline Autoimagem & 12 & $6-8$ \\
\hline Autoimagem & 24 & $29-32$ \\
\hline Autoimagem & 28 & 6 \\
\hline Colaboração & 2 & $30-31 ; 35-41$ \\
\hline Colaboração & 6 & 7 \\
\hline Colaboração & 9 & $20-26$ \\
\hline Colaboração & 11 & $24-29$ \\
\hline Colaboração & 16 & $22-29$ \\
\hline Colaboração & 19 & $14 ; 19$ \\
\hline Colaboração & 21 & $27-28 ; 31$ \\
\hline Colaboração & 31 & $5-16$ \\
\hline Crescimento & 3 & 9-13; \\
\hline Crescimento & 10 & 1 \\
\hline Crescimento & 17 & $7-8$ \\
\hline Decisão & 26 & $22-26$ \\
\hline Decisão & 29 & $5-6 ; 12$ \\
\hline Destaque & 13 & $15-17$ \\
\hline Destaque & 16 & $15-16$ \\
\hline Destaque & 24 & $17-19$ \\
\hline Emocional & 25 & $8-12$ \\
\hline Emocional & 30 & $9-11$ \\
\hline Emocional & 1 & $6 ; 22-26 ; 30-33$ \\
\hline Emocional & 3 & $04-06$ \\
\hline Emocional & 19 & 28 \\
\hline Humor & 11 & $29-34$ \\
\hline Humor & 12 & $20-21$ \\
\hline Identificação & 12 & $3-4$ \\
\hline Identificação & 2 & 8-11; \\
\hline Identificação & 9 & $3-5$ \\
\hline Identificação & 13 & $1-5$ \\
\hline Identificação & 16 & $5-6$ \\
\hline Identificação & 21 & $13-14$ \\
\hline Identificação & 24 & $13-14$ \\
\hline Imposição & 15 & $8-9 ; 13-21$ \\
\hline Imposição & 16 & 9-11 \\
\hline Imposição & 16 & 32 \\
\hline Imposição & 23 & $7-13$ \\
\hline
\end{tabular}




\begin{tabular}{|l|l|l|}
\hline Imposição & 23 & $17-21$ \\
\hline Inovação & 17 & 28 \\
\hline Leveza & 23 & 29 \\
\hline Ocupação & 10 & $22-29$ \\
\hline Pertencimento & 21 & $9-10$ \\
\hline Recomendação & 10 & $14-18$ \\
\hline Recomendação & 22 & $14-15$ \\
\hline Recomendação & 10 & 13 \\
\hline Recomendação & 22 & $16-20$ \\
\hline Satisfação & 22 & $2-3$ \\
\hline Satisfação & 28 & $23-24$ \\
\hline Social & 4 & $11-13$ \\
\hline Social & 15 & $24-26$ \\
\hline Social & 8 & $1-2$ \\
\hline Social & 18 & 11 \\
\hline Social & 20 & $25-33$ \\
\hline Social & 21 & 21 \\
\hline Social & 22 & 23 \\
\hline Social & 25 & $1-5$ \\
\hline Social & 25 & $16 ; 19-27$ \\
\hline Social & 26 & $8-12$ \\
\hline Social & 27 & $3-5 ; 10-12 ; 15-18 ; 21-22$ \\
\hline Transforma & 3 & $16-17$ \\
\hline Transforma & 10 & $4-9$ \\
\hline Transforma & 17 & 11 \\
\hline Transforma & 22 & $9-10$ \\
\hline Transforma & 25 & $31-33$ \\
\hline & & \\
\hline & 22 \\
\hline
\end{tabular}

Fonte: elaborado pela autora

Percebe-se que os temas foram colocados em ordem alfabética para facilitar a análise, e que as ideias anotadas nas diversas etapas foram coletadas em uma lista. Finalmente, com esse material, foi resumido o texto e julgado por sua inclusão tendo como base o ponto de vista dos participantes, as dicas em relação à verdade e à integralidade dos fatos relatados, à veracidade com relação ao que foi dito nas entrevistas, ao que foi contraposto durante as observações dos compartilhamentos no Facebook (FLICK, 2004).

Tendo a visão mais holística da análise global, e a análise de conteúdo de Mayring (2014), foram trabalhadas as categorias estabelecidas pela revisão da literatura e da transcrição dos dados das entrevistas realizadas. Inicialmente cumpriu-se a primeira etapa 
da análise de conteúdo em que o material analisado foi definido e as partes das entrevistas que são relevantes para solução da questão de pesquisa foram selecionadas.

$\mathrm{Na}$ segunda etapa foi realizada a análise da situação da coleta de dados. O detalhamento da situação da coleta de dados já foi apresentado no tópico "entrevista e transcrição de dados", porém, cabe detalhar que durante as entrevistas não houve a presença de ninguém além do entrevistado e da pesquisadora, foram escolhidos pelos entrevistados locais tranquilos para que as entrevistas fluíssem naturalmente e sem interrupções. A maioria dos respondentes autorizou a menção dos seus nomes no trabalho. Os respondentes que não aceitaram ter o nome mencionado no trabalho terão as iniciais dos seus nomes abreviados. As autorizações foram coletadas oralmente com gravação. $\mathrm{Na}$ tabela abaixo seguem as informações gerais dos respondentes:

\section{Tabela 7 - Dados dos respondentes}

\begin{tabular}{|l|r|l|l|}
\hline \multicolumn{1}{|c|}{ Nome } & \multicolumn{1}{|c|}{ Idade } & \multicolumn{1}{c|}{ Escolaridade } & \multicolumn{1}{c|}{ Profissão } \\
\hline Maria Vicentina Giovanini & 61 & Superior completo & Vendedora \\
\hline Janete Ursulina de santos de Souza & 63 & Superior completo & Autônoma \\
\hline Maria Raimunda Pereira da Silva & 60 & Superior incompleto & Empresária \\
\hline Ademir Jose de Souza & 64 & Superior incompleto & Autônomo \\
\hline IM & 76 & Fundamental & Aposentada \\
\hline AV & 61 & Mestre & Professor e consultor \\
\hline JO & 61 & Fundamental & Do Lar \\
\hline Manuela Mazzini & 65 & Superior completo & Médica \\
\hline MD & 69 & Pós-graduado & Professor \\
\hline SM & 61 & Doutor & Professor \\
\hline
\end{tabular}

Fonte: elaborado pela autora

Todos os entrevistados disponibilizaram todos seus compartilhamentos para serem analisados no Facebook, nenhum dado ficou restrito ao perfil da pesquisadora. De todos entrevistados somente a JO e a IM não estão atuando no mercado de trabalho, dos dez entrevistados três possuem superior completo, duas possuem superior incompleto, um é mestre, um é doutor, um é pós-graduado e dois possuem ensino fundamental. 
Todas entrevistas foram gravadas, o que confere a caracterização formal do material coletado e a terceira etapa da análise qualitativa de conteúdo. As entrevistas ocorreram em São Paulo, sendo as entrevistas da Maria Vicentina, Janete, Maria Raimunda e Ademir ocorreram em 25 de junho de 2017, em São Bernardo do Campo. Já em 28 de junho de 2017 realizada a entrevista da IM, no Jardim Marajoara e a entrevista da Manuela, na vila Mascote. Em 29 de junho de 2017 foram realizadas as entrevistas de MD e SM em Santo Amaro. Já em 30 de junho de 2017 foi realizada a entrevista do AV na Barra Funda. Já e em dois de julho de 2017 foi realizada a última entrevista, da JO, no Jardim Climax.

$\mathrm{Na}$ quarta etapa, com material selecionado da análise global, foi dada a direção para o texto, para que a questão de pesquisa seja respondida, tendo como base no roteiro semiestruturado, pré-estabelecido com base no referencial teórico, detalhado no capítulo três e posto integralmente em apêndice. O roteiro semiestruturado apresentou perguntas para as categorias estabelecidas a priori, que estão respaldadas no referencial teórico.

O aprofundamento da análise tomou como base a questão de pesquisa, visando encontrar a solução com base no material analisado. Já as técnicas analíticas adotadas para as respostas dos respondentes foram:

a) Abreviação da análise de conteúdo, parafraseando o material, reduzindo trechos, condensando trechos;

b) Análise explicativa de conteúdo, esclarecendo trechos complexos;

c) Análise estruturadora do conteúdo, apontando estruturas formais no material, buscando aspectos únicos e evidentes no material e detalhando-os.

No que se refere as unidades analíticas, com base na análise global e no aprofundamento da análise qualitativa de conteúdo a partir da pergunta de pesquisa e do referencial teórico que proporcionou as categorias definidas a priori, foram criadas as unidades analíticas para este estudo. A tabela abaixo aponta quais foram as categorias definidas a priori com base no referencial teórico, e novas, estabelecidas por: entrevistas, subcategorias e unidades analíticas. 
Tabela 8 - Análise qualitativa de conteúdo

\begin{tabular}{|c|c|c|}
\hline Categoria & Subcategoria & Unidade analítica \\
\hline \multicolumn{3}{|l|}{ Estabelecidas a priori } \\
\hline Inclusão & Aceitação & Ser aceito \\
\hline Inclusão & Identificação & Modo de pensar e agir \\
\hline Inclusão & Pertencimento & Fazer parte de um grupo \\
\hline Individualidade & Autoimagem & Marcar a individualidade \\
\hline Individualidade & Destaque & Marcar a individualidade \\
\hline Afeição/Altruísmo & Colaboração & Ajudar o receptor \\
\hline Afeição/Altruísmo & Decisão & Apoio à tomada de decisão \\
\hline Afeição/Altruísmo & Emocional & Harmonia \\
\hline Controle & Crescimento & Crescimento pessoal \\
\hline Controle & Transformação & Ensinamentos aos receptores \\
\hline \multicolumn{3}{|c|}{ Estabelecidas a posteori } \\
\hline Análise de perfil & Identificação & Comportamento \\
\hline Boca a boca negativo & Recomendação & Informação \\
\hline Boca a boca positivo & Recomendação & Informação \\
\hline Comunicação ativa & Inovação & Aprendizado \\
\hline Comunicação ativa & Ocupação & Dinamismo \\
\hline Comunicação ativa & Social & Aprendizado \\
\hline Comunicação ativa & Social & Interesse do receptor \\
\hline Comunicação ativa & Social & Contato social \\
\hline Descontração & Leveza & Relaxamento \\
\hline Diversão & Humor & Diversão para o emissor \\
\hline Educação & Aprendizado & Aprendizado \\
\hline Educação & Atualidade & Atualizado \\
\hline Educação & Aprendizado & Apoio tomada de decisão do jovem \\
\hline Estímulo emocional & Emocional & Emociona \\
\hline Estímulo emocional & Satisfação & Satisfação pessoal do emissor \\
\hline Proliferação de ideia & Imposição & Imposição de ideias \\
\hline
\end{tabular}

Fonte: elaborado pela autora 


\subsection{Análises da pesquisa qualitativa de conteúdo}

Neste tópico são apresentadas as análises qualitativas de conteúdo com base nos dados advindos das entrevistas (Flick, 2004; Mayring, 2014) para todas novas categorias e para cada categoria definida a priori, que são:
a) Inclusão;
b) Individualidade;
c) Afeição/altruísmo; e
d) Controle.

\subsubsection{Inclusão}

A) Subcategoria aceitação

Os entrevistados consideram essa subcategoria importante para terem 0 comportamento do compartilhamento, mas ela não é essencial para todos. Somente quatro dos entrevistados responderam que a aceitação por parte do (s) receptor (es) é uma motivação para que a comunicação boca a boca ocorra.

Os entrevistados mencionaram que se os receptores partilham da mesma ideia, há a aceitação ao receber o compartilhamento, mas que isso é uma consequência da realização da comunicação boca a boca em meio digital, não sendo uma motivação. Em complementação a esta constatação, pode-se destacar o pronunciamento da entrevistada Janete: "não, esse sentimento de aceitação não, porque o conteúdo não fui eu que coloquei, já veio de outra pessoa. Então, o Face não é pessoal, nesse aspecto não, ele é geral, a aceitação não".

Percebe-se assim, que o Facebook, nomeado pela entrevistada e por outros entrevistados diversas vezes como Face, é utilizado para comunicação boca a boca, mas não com a intenção de ser aceito por alguém ou por algum grupo. Em conformidade, MD afirma que quando se compartilha algum conteúdo se compartilha uma ideia, e esse é o 
interesse do compartilhamento para ele, a multiplicação, a viralização, permitir que o maior número de pessoas possíveis tenha a mesma ideia que a do emissor. Porém, o entrevistado aponta que ele realiza a comunicação boca a boca sem essa motivação explicitamente ou conscientemente.

Foi apontado que a comunicação boca a boca pode inclusive proporcionar a não aceitação por parte do receptor da mensagem. Assuntos mais polêmicos como por exemplo religião, foram citados como temas que despertam essa possibilidade. Alguns depoimentos como os de AV e JO foram dados explicitando a rejeição do receptor: “aceitação não sei, pode acontecer até o contrário. Como já aconteceu de pessoas que ficaram muito bravas com algo que eu postei, algo ligado à religião, colocando questionamento sobre a religião, Deus, e tem pessoas que se ofendem com isso", “... depende do conteúdo porque as vezes pode afastar a pessoa. Tem coisas que as pessoas aceitam e outras não".

Em contrapartida, os entrevistados que possuem a necessidade de aceitação de pessoas e grupos como motivação para a realização do boca a boca acreditam que a comunicação boca a boca em meio digital proporciona a aceitação e a aproximação de pessoas que estavam distantes dos emissores das mensagens, sejam eles parentes ou amigos. Foi citado que a aceitação de desconhecidos não é importante.

B) Subcategoria identificação

Essa subcategoria aponta os respondentes que têm como motivação a realização da comunicação boca a boca com mensagens que identificam seus modos de pensar e agir. Para quase todos os respondentes seus compartilhamentos necessariamente mostram quem eles são, como agem, como pensam.

Para Maria Vicentina ser clara é importante ao realizar o boca a boca, e sendo clara ela indica que está sendo verdadeira, ela mesma. Para ela, a partir do momento que ela está sendo verdadeira, as pessoas reconhecem isso e a identificam assim. O mesmo discurso foi feito pela Maria Raimunda, que apontou que em seus compartilhamentos ela é sempre sincera, mostrando seu modo de pensar e agir.

Foi apontado que as mensagens são enviadas porque os emissores gostaram do que estavam compartilhando, e que isso então apontava seu modo de pensar e agir. $\mathrm{Na}$ 
declaração de MD ficou claro que ele não concorda ele não passa na comunicação boca a boca. Em contrapartida, para SM não tem como não mostrar seu modo de agir e pensar:

Eu tenho um bloqueio emocional, eu vou pela emoção do momento, mas no Face eu me seguro porque as palavras vão e a sensação fica. Então, não coloco, tomo um pouco de cuidado. Mas todo mundo que acompanha o meu Face sabe as minha direções políticas, o que eu penso. Desse tipo de coisa não tenho como escapar, não me envergonho com nada que eu compartilho.

Houve uma declaração inclusive da Manuela que ela acredita que realizar a comunicação boca a boca do que ela não pensa pode não ser ruim, mas ela acredita ser incoerente, e por isso ela só é motivada por coisas que identificam seu modo de pensar e agir.

Os respondentes que realizam comunicação boca a boca em meio digital sem identificar seus modos de pensar e agir afirmam que não querem se expor, para Ademir, não quer dizer que ele não aja conforme alguma mensagem que compartilhou, conforme algum boca a boca que realizou, mas nem sempre o que ele compartilha reflete de verdade seu modo de pensar e agir, e isso para ele, não é uma motivação para realização da comunicação boca a boca em meio digital.

C) Subcategoria pertencimento

No que se refere a subcategoria pertencimento, são poucos os respondentes que necessitam fazer parte de um grupo, eles não entendem a questão do pertencimento como uma motivação. Não se identificam como pessoas pertencente a alguma ação ao realizar o boca a boca. A maioria dos respondentes entendem que compartilham assuntos diversos para vários tipos de receptores também.

Quando o respondente afirmou que gostava de pertencer a algum grupo, coisas relacionadas ao altruísmo foram citadas, como por exemplo o GRAACC (Grupo de Apoio ao Adolescente e à Criança com Câncer), em que a entrevistada Maria Raimunda disse fazer questão de realizar a comunicação boca a boca de assuntos relacionados à essa empresa e à ajuda as crianças.

A questão da religião também foi apontada, a entrevistada Janete disse que compartilha coisas sobre religião com a intenção de ensinar pessoas e ajudar em 
momentos difíceis da vida. Já JO aponta: “adoro postar, compartilhar e receber porque é um assunto do meu interesse, eu gosto de fazer uma experiencia, algum prato que tenha feito". Assim, percebe-se que JO faz questão de ser reconhecida como uma pessoa que cozinha bem, que está relacionada as questões da culinária.

\section{Figura 7 - Comunicação boca a boca - religião}

Janete Ursulina Jane compartilhou o video de William Moreira.

$17 \mathrm{~h} \cdot \mathrm{a}$

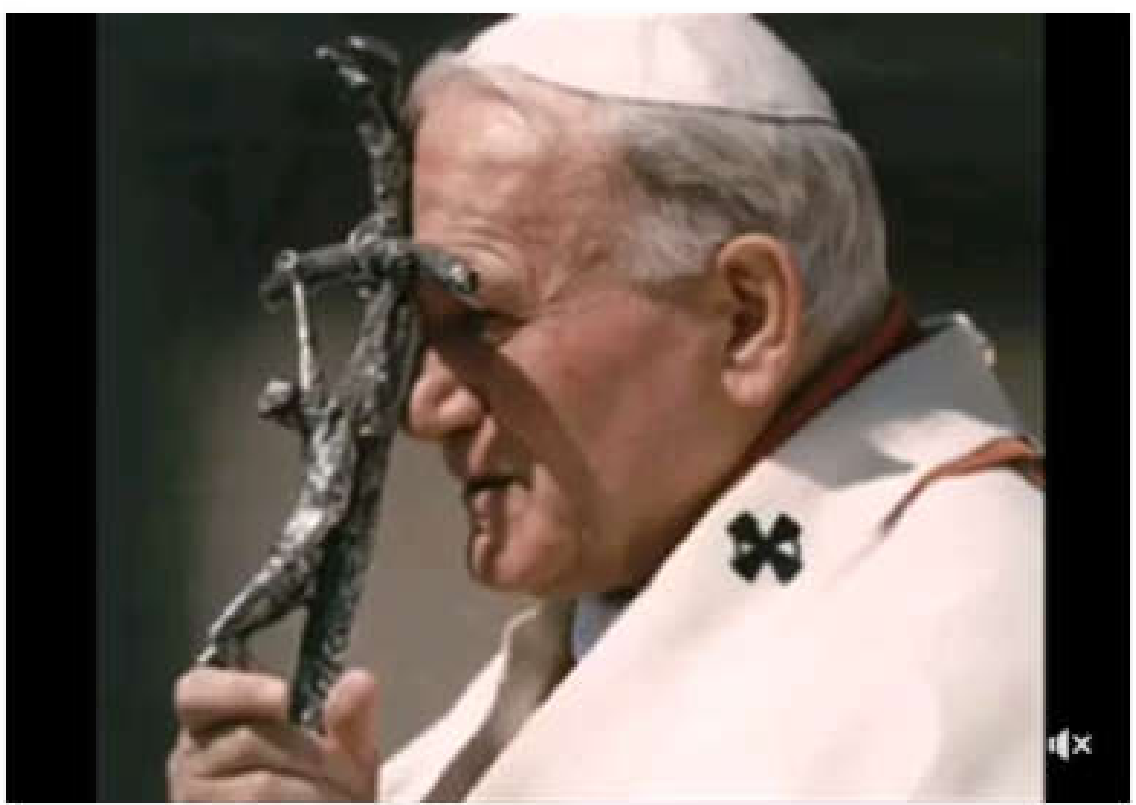

66. 500 visualizap̧ôes

William Moreira adicionou um novo video

2 de novembro de 2015 .

1. Curtir Página

Assista este lindo vídeo, com Säo Joâo Paulo II, ouvindo a música peregrino do amor.

Se gostar CURTA.A PÁGINA CATÓLICA facebook.comivilliammoreirafranca $\vartheta$

\section{Curtir \\ Comentar \\ Compartilhar}

Fonte: https://www.facebook.com/janeteursulina.jane

A entrevistada JO informou que sempre realiza comunicação boca a boca de assuntos sobre culinária, que é um assunto do seu interesse e que faz questão de pertencer a grupos que tratam desse assunto e de ser reconhecida por isso. 
Após a análise das três subcategorias da categoria inclusão, cabe a análise da premissa 2: a necessidade de ter pelo menos uma relação interpessoal é uma motivação para a realização da comunicação boca a boca em meio digital.

Tendo em vista a análise dos dados, pode-se confirmar a premissa 2 parcialmente.

\subsubsection{Individualidade}

\section{A) Subcategoria autoimagem}

Nessa subcategoria é checada a necessidade de o respondente marcar a sua individualidade com a realização do boca a boca de coisas referente a sua autoimagem.

Ao analisar os dados das entrevistas percebeu-se que poucos foram os entrevistados que afirmaram que marcar a individualidade com a autoimagem são motivações para a realização do boca a boca. IM afirmou que realiza esse tipo de boca boca somente com pessoas da família e não na página do Facebook para todos verem.

Manuela que concorda que faz boca a boa com sua autoimagem, afirma que não tem feito com frequência, mas que eventualmente compartilha fotos da sua autoimagem quando dá palestras em congressos. Concorda que já compartilhou mais coisas desse gênero ao longo dos últimos anos no Fcebook, mas que foi diminuindo o boca a boca com aspectos pessoais, de autoimagem para realizar o boca a boca de coisas mais gerais, mais cultura, mais informação.

$\mathrm{JO}$, por exemplo informou que não realiza este tipo de compartilhamento porque não quer se expor. Porém, ao se observar as páginas do Facebook dos entrevistados, percebeu-se que quase todos realizam o boca a boca com autoimagem, mas nem sempre assumem: "gosto que as pessoas me enxerguem e não gosto de mostrar como sou" (MD), "não compartilho nada da minha autoimagem" (Maria Raimunda), "não realizo boca a boca de coisas da minha autoimagem porque ela é minha" (SM), "não compartilho autoimagem, só os teste que são disponibilizados no Facebook que analisam seu perfil e apontam suas características. Por exemplo os testes feitos especificamente para mulheres e eu compartilho porque achei legal. Tem uns que são inteligentes", "compartilho por diversão, coisas que são engraçadas, faço alguns, mas compartilho poucos” (AV). 
Figura 8 - Autoimagem - Maria Raimunda
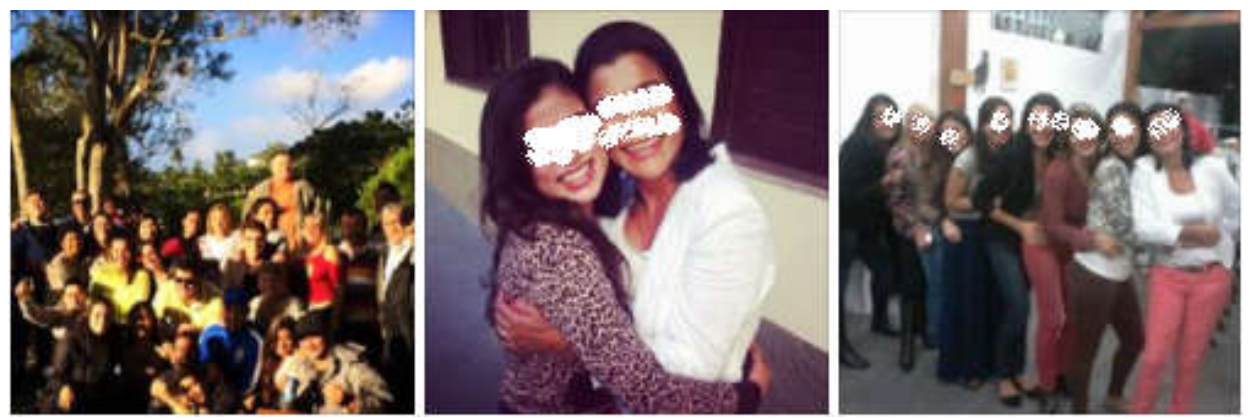

Fonte:www.facebook.com/profile.php?id=100005248689625\&lst $=100002124702989 \%$ $3 \mathrm{~A} 100005248689625 \% 3 \mathrm{~A} 1500567300 \& \mathrm{sk}=$ fotos

\section{Figura 9 - Autoimagem - SM}

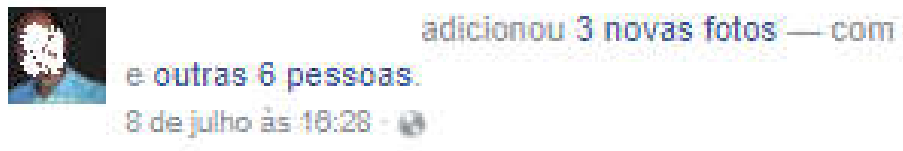

E hoje mais três grupos de TCC (alguns com plateia). Junto comigo na banca
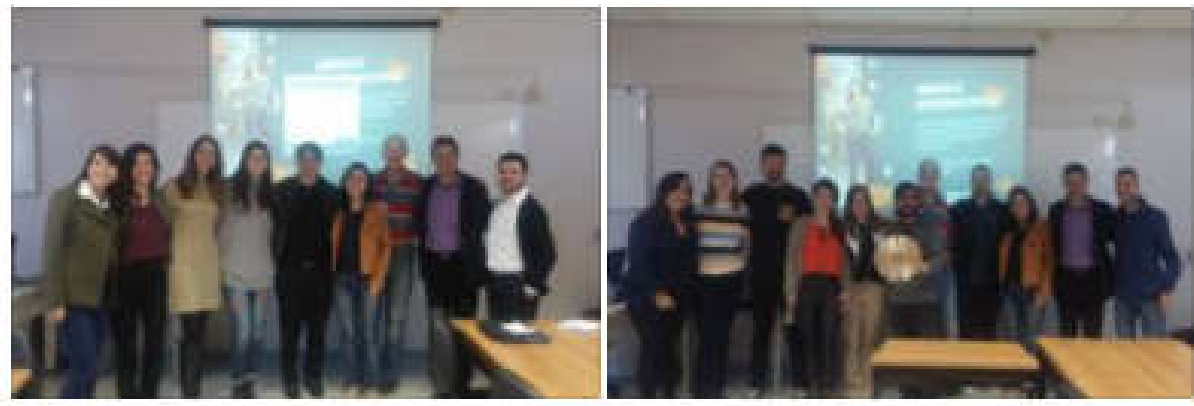

1. Curtir Comentar $\rightarrow$ Compartilhar
0047

Fonte: www.facebook.com 


\section{Figura 10 - Autoimagem - AV}

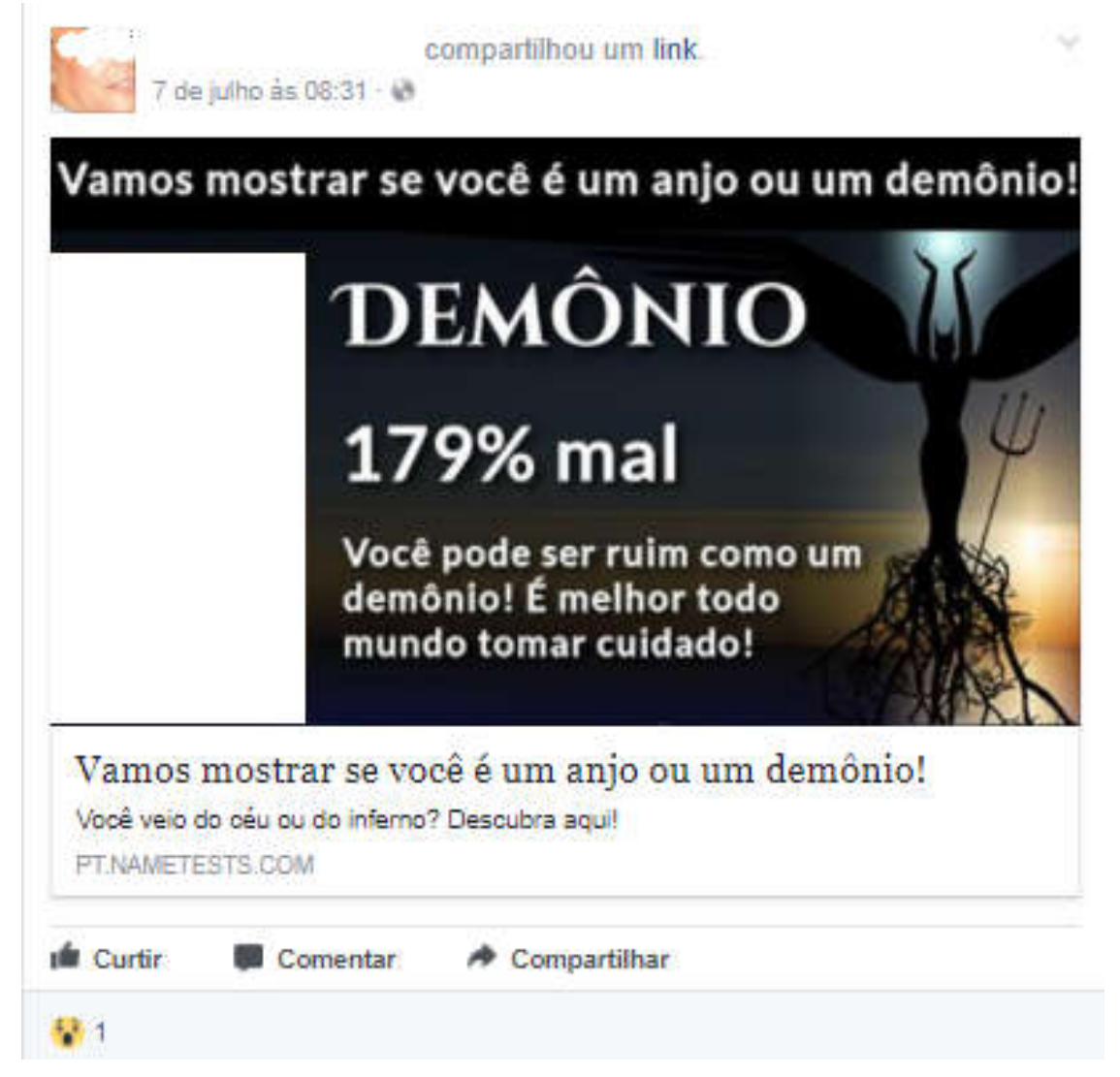

Fonte: www.facebook.com

B) Subcategoria destaque

Nessa subcategoria percebeu-se que poucos entrevistados têm a necessidade de marcar a individualidade se destacando com seu boca a boca. Eles acreditam que não se destacam porque estão fazendo o boca a boca com assuntos e mensagens que todo mudo também usa, ou seja, não são assuntos ou mensagens exclusivas dos emissores. As mensagens exclusivas poderiam gerar destaque, mas os entrevistados não são motivados a criar este tipo de mensagem. A menos que sejam mensagens para manter o relacionamento social ativo. 
Para Ademir o destaque não é uma motivação porque existem muitas pessoas falando muitos assuntos na internet, e ele como emissor é apenas mais um que está tentando se expressar, mandar uma mensagem para alguém.

Os respondentes que querem destaque assim como Manuela afirmam que o destaque é importante para compartilhar: "é meio prepotente isso, é pernóstico, mas lá no fundo eu acredito que sou melhor que alguns outros. Assim como eu tenho algumas pessoas que assim que eu vejo eu já vou ler o que elas compartilharam porque são próximas, são cultas, identificadas com ideias abertas".

Muito embora o destaque seja importante, a entrevistada Manuela aponta que compartilha pensando que os meus amigos vão ver e os amigos dos amigos vão ver se esses compartilharem sua comunicação boca a boca, mas ela afirma que não fica olhando quantas curtidas teve, ela afirmou somente que as vezes vê um comentário, não se preocupando muito com o acompanhamento da comunicação e sua repercussão final.

Pode-se perceber que entrevistados como SM, MD, JO não têm como motivação o destaque para realizar o boca a boca, mas afirmaram que se percebessem que suas comunicações boca a boca proporcionariam destaque sempre, fariam com mais frequência porque para eles traria destaque intelectual, reconhecimento de alguém que ajuda as pessoas e maior convívio social respectivamente.

Para SM seus compartilhamentos são melhores do que os dos demais usuários da internet, mas não geram destaque: "eu diria o seguinte, não querendo me gabar, mas eu acho que meus posts são todos de nível, mas não vou dizer que é melhor do que o do outro, até porque não é o foco do Face, não é? ". Assim, percebe-se que o respondente não identifica as redes sociais como um local para destaque. Porém, se pudesse se destacar ele realizaria mais comunicação boca a boca do que faz atualmente: "as vezes algum tema que você pega te dá uma alavancada, é mais um alimento intelectual do que qualquer coisa. ...alguma coisa que você fez ter resultado, um tema que eu gosto, que escrevi, compartilhei teve bastante curtida". O respondente aponta a preocupação com a repercussão da sua comunicação boca a boca, visualizações, comentários e curtidas.

Tendo em vista a análise das subcategorias da categoria individualidade, cabe a análise da premissa 3: O boca a boca em meio digital é motivado pela possibilidade do indivíduo marcar sua identidade, se diferenciar. 
Confere-se na análise dos dados que a premissa 3 é verificada somente em alguns dos respondentes.

\subsubsection{Afeição/Altruísmo}

A) Subcategoria colaboração

Somente os respondentes SM e IM não têm a motivação de ajudar os receptores com seus compartilhamentos. SM aponta que realiza a comunicação boca a boca com a intenção de ajudar seletivamente, pois se um conhecido lhe pede ajuda para difundir um assunto ele acaba ajudando, mas afirma que precisa ser importante, e que jamais faz isso para pessoas desconhecidas ou casos que não sabe se são verdadeiros. Já a IM, não acredita que pode ajudar outras pessoas com seu compartilhamento.

Os demais respondentes têm a ajuda aos outros usuários da internet com quem realizam a comunicação boca a boca como motivação imprescindível. Eles afirmam ser uma forte motivação, que ao mesmo tempo que estão aprendendo com suas mensagens também gostariam de ensinar seus receptores com o boca a boca que realizam.

A ajuda aos receptores foi explicitada como um ensinamento ou algum apoio de aspectos gerais. Também foi apontado que o boca a boca com a motivação de ajudar os receptores ocorreu especificamente em grupos familiares e de amigos dos emissores, que também foram bastante citados nesse item. Janete afirmou: "ah, ajudando eu mando mesmo", mostrando que uma das suas principais motivações para a realização da comunicação boca a boca é o altruísmo.

Foi citado como exemplo por MD o compartilhamento de vagas de emprego, que também citou outros usuários idosos e jovens que realizavam o mesmo tipo de comunicação boca a boca, que foram muito elogiados com suas posturas, o que mostra a grande motivação de MD para a realização da comunicação boca a boca. 
B) Subcategoria decisão

Foi apontado também pelas respondentes IM e Manuela, dentro da categoria afeição/altruísmo que o apoio a tomada de decisão é uma motivação, que também foi identificada como uma subcategoria da categoria educação (definida a posteriori).

Nessa categoria, os outros respondentes acreditam que ajudar as pessoas realizando o boca a boca pode colaborar com a tomada de decisão, mas que eles fazem de forma mais inconsciente. Para SM, se ele soubesse que sua comunicação boca a boca iria influenciar a tomada de decisão dos receptores, ele não a faria. Ou seja, não é uma motivação para esse respondente.

\section{Figura 11 - Afeição/altruísmo - Decisão - Manuela}

\section{Manuela Mazzini}

11 de juho às $14: 31 \cdot 4$

\section{Olhem Bernardo Nunes Mazzini e Vanessa Spada Apolinario Mazzini}

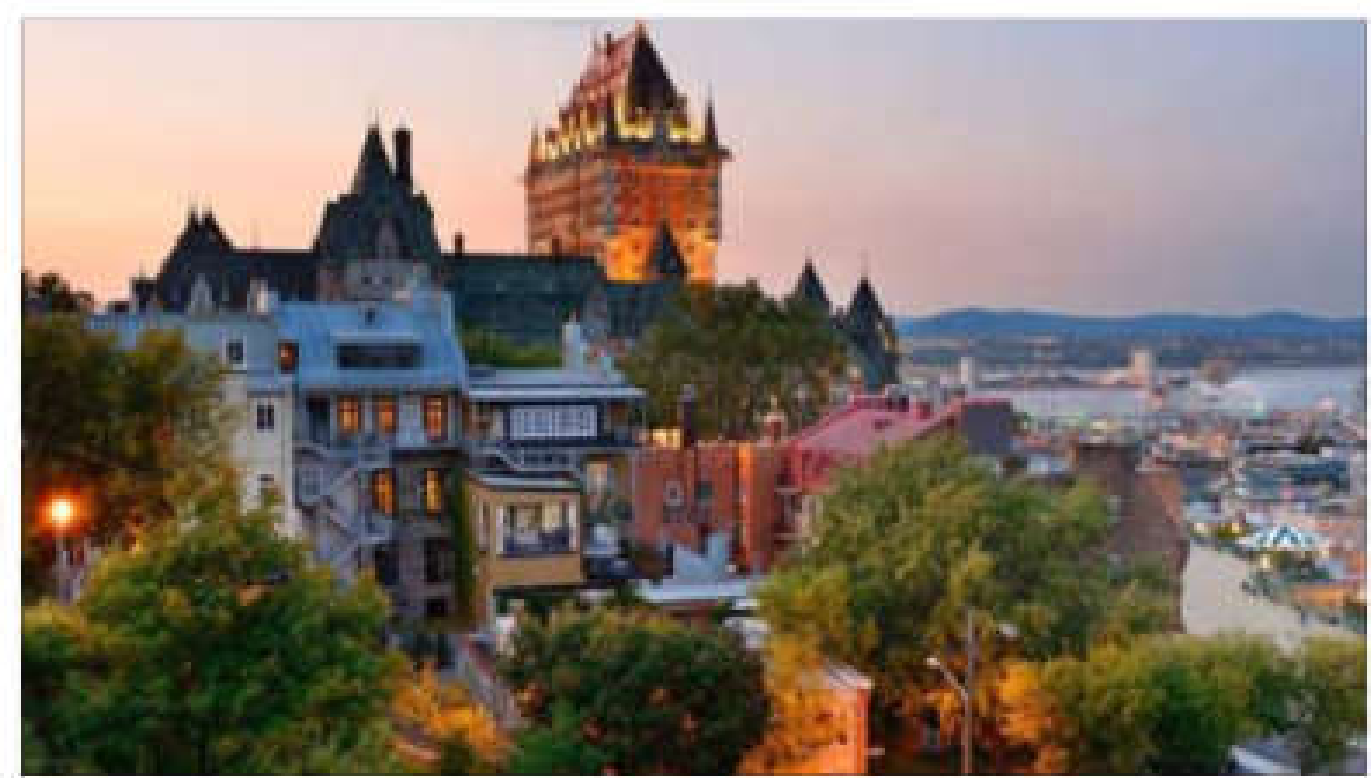

\section{Missão do Canadá busca brasileiros para trabalhar lá}

Săo 81 vagas anunciadas e grande parte é na área de tecnologia da informạ̧ăo e... EXAME.ABRIL COM.BR

- Curtir Comentar $\leadsto$ Compartilhar

\section{2}

Fonte: https://www.facebook.com/manuela.mazzini.52 


\section{C) Subcategoria emocional}

Os respondentes acreditam que é uma motivação provocar o acolhimento emocional nos seus receptores, apontam que gostam de promover esse acolhimento com seus compartilhamentos. Para Maria Vicentina, o compartilhamento é realizado porque ela acredita que vai mexer com o emocional do receptor:

As vezes naquele momento a pessoa estava precisando ouvir uma frase legal, uma história legal que vai mexer com emocional dela e que vai ajudar. [...] Boas energias, naquele momento a pessoa está precisando de uma ajuda, ela não tá muito bem, então às vezes ela ouve aquela frase, parece que entra dentro dela, dá uma mexidinha, ela fica mais feliz, e daí para frente ela trilha outro caminho.

Para IM quanto mais ela se relaciona com outros usuários, o que denota que a comunicação ativa é uma motivação importante para essa respondente, maior será a possibilidade de gerar acolhimento emocional. Ou seja, a comunicação boca a boca gera um relacionamento e este permite o acolhimento emocional, e que esse acolhimento, assim como as relações sociais (detalhadas na categoria comunicação ativa), são motivações.

Em contrapartida, SM acredita que somente conseguiria proporcionar acolhimento emocional para alguém pessoalmente. Ele menciona que o conforto emocional é o ombro, que isso não dá para ser feito pelo boca a boca em meio digital. 
Figura 12 - Acolhimento emocional - MD

DCE Unittalo com

e outras

1. Curtir Página

41 pessoas.

15 de outubro de 2014 - a

Professores

Mais do que meros transmissores de conteúdo, vocês são curadores do conhecimento, orientadores de projetos de vida e vendedores de sonhos.

Parabéns por esta data especial e pelo comprometimento e amor diário!

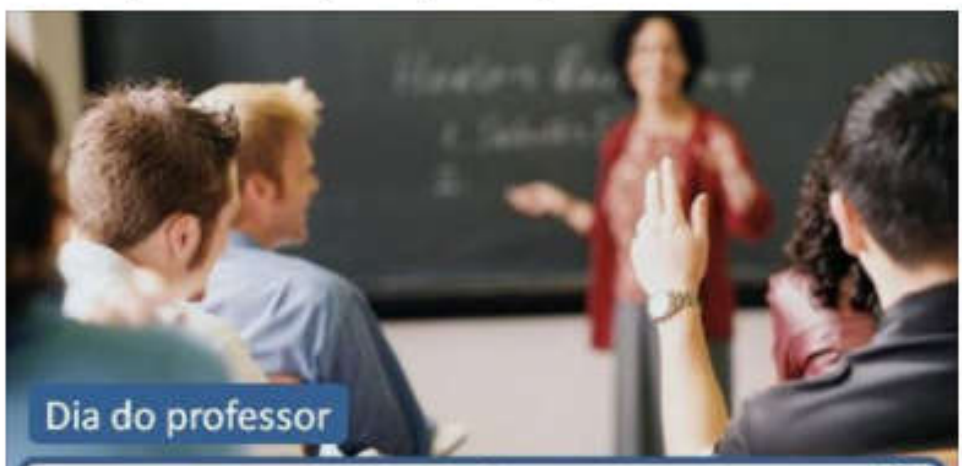

O item mais bem avaliado do Unif́talo não é um recurso físico,

são pessoas que transformam vidas. São os nossos professores DCE

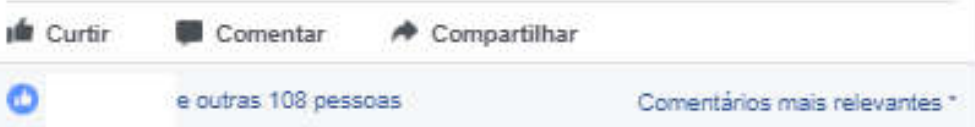

1 compartilhamento

8. Escreva um comentário... (0)

19. Vurtir Responder 0 1 - 15 de outubro de 2014 às $18: 30$

Fy Obrigado a todos, amo vocês todos.

Ourtir Responder 0 1 - 15 de outubro de 2014 às $13: 07$

Fonte: www.facebook.com.br

Ao analisarmos a premissa 4: O altruísmo motiva o encaminhamento online de mensagens por idosos usuários da internet.

Com a análise das respostas coletadas em campo, pode-se perceber que ela somente não foi verificada nas respostas do respondente SM. 


\subsubsection{Controle}

A) Subcategoria crescimento

Não é motivação para os respondentes o alcance dos seus objetivos pessoais por meio da realização do boca a boca a menos que os objetivos pessoais estejam relacionados a alguma categoria estabelecida a priori ou a posteriori como educação, estímulo emocional, afeição/altruísmo, proliferação de ideia ou comunicação ativa. A Maria Vicentina, por exemplo, apontou a gratificação que ela tem em ajudar outras pessoas, mostrando que isso gera um sentimento bom para ela que é um objetivo pessoal. Já Manuela diz que conforme você compartilha algo com alguém em que o emissor acredita, o receptor te devolve isso compartilhando outros assuntos relacionados que vão te agregar. Assim, para ela, existe uma troca na rede social que ajuda nos momentos de solidão também.

A Maria Raimunda não tem como motivação o atingimento dos seus objetivos pessoais para a realização da comunicação boca a boca. Ela acredita que esse não é o caminho para alcança-los.

Em concordância com Maria Raimunda está a opinião da Janete, que afirma que não tem nenhuma relação com o que ela planeja para vida dela: "por exemplo planejo uma viagem, a comunicação boca a boca no Face não vai me dar". Ela ainda aponta que quando vai pegar indicações não vai perguntar no Face para todos, ela vai perguntar para quem conhece especificamente do assunto. AV aponta que seus objetivos pessoais estão relacionados às questões profissionais, e que o seu boca a boca no Facebook não é para questões profissionais. Contradizendo AV, IM diz que faz ela alcançar seus objetivos pessoais sim porque ela faz propagandas para seus trabalhos no Facebook, e essa comunicação boca a boca a ajuda nas vendas.

Complementarmente, SM afirma que não alcança seus objetivos pessoais com seus compartilhamentos na rede social Facebook porque a rede é volátil, o que ele coloca hoje em sua página da rede social, amanhã já não existe, não perdura, são como palavras ao vento.

$\mathrm{O}$ respondente MD acredita que seus compartilhamentos ajudam no alcance dos seus objetivos pessoais, pois ele tem a intenção de proliferar a sua ideia e com o boca a boca ele tem mais chances de alcançar esse objetivo, por isso, trata-se nesse caso de uma motivação importante. 
No que se refere ao crescimento pessoal, oito dos respondentes concordaram que é uma motivação importante, pois ajuda o emocional tanto do emissor quanto do receptor. Outro aspecto levantado pelos respondentes é que eles aprendem e ensinam com suas comunicações boca a boca.

Foi apontado por MD que realizar a comunicação boca a boca para bons contatos (pessoas com boas relações profissionais) proporciona o sucesso e o crescimento pessoal e isso é uma forte motivação para ele.

IM aponta que a comunicação boca a boca traz o crescimento pessoal porque a aproxima do mundo digital, a faz aprender coisas ligadas à internet e isso é uma motivação importante para ela.

AV e Ademir não concordam com os oito demais respondentes porque acreditam que utilizam o Facebook com objetivos diferentes dos profissionais, que para eles, estão ligados ao crescimento pessoal.

Quando analisamos a premissa 5 - $O$ desenvolvimento pessoal motiva o boca a boca em meio digital - consegue-se compreender, baseado nas entrevistas, que ela é verificada somente em alguns respondentes.

B) Subcategoria transformação

Oito respondentes têm como motivação para o boca a boca a transformação, ou seja, eles acreditam que fazem a diferença no ambiente social em que participam especialmente com ensinamentos aos receptores.

Os respondentes que não têm a transformação como categoria são Ademir e a Maria Raimundo. Eles alegam que não querem ser prepotentes,

\subsubsection{Análise de perfil}

A) Subcategoria identificação

Essa subcategoria foi apontada como motivação para o respondente SM, que alegou que compartilha conteúdos diversos com seus contatos no Facebook com a motivação compreender os perfis dos receptores, compreendendo seus gostos, costumes, hábitos, o 
que não agrada e como geralmente lidam com determinada comunicação boca a boca feita por SM.

Os compartilhamentos feitos diretamente aos outros usuários não puderam ser checados, mas os compartilhamentos realizados na página pública do Facebook do respondente SM não comtemplam uma comunicação boca a boca que explicitamente queira identificar os perfis dos outros usuários no Facebok. Contudo, o respondente confirmou que analisa as pessoas que comentam sobre sua comunicação boca a boca, o que gostam etc.

\subsubsection{Boca a boca positivo e negativo}

A) Subcategoria recomendação

Quatro dos entrevistados (Maria Vicentina, Maria Raimunda, SM, IM e Ademir) não têm como motivação a realização do boca a boca positivo para empresas. Eles alegam que não realizam esse tipo comunicação sobre empresas. Maria Vicentina inclusive afirmou que não compartilha nem as piadas que recebe com questões empresariais porque denigrem a imagem das empresas envolvidas. A respondente alega também que não sabe se os compartilhamentos recebidos sobre empresas são verdadeiros, por isso não compartilha.

Os outros respondentes afirmaram que a realização do boca a boca positivo é uma motivação. Porém, não foram encontradas evidências desse comportamento em todos perfis do Facebook.

Oito respondentes (Maria Vicentina, SM, MD, AV, JO, Manuela, IM) não se sentem motivados para realizar o boca a boca negativo. Não sabem se as informações são verdadeiras, e acreditam que irão prejudicar a empresa e os funcionários que trabalham nela. De acordo com AV, ele não realiza boca a boca negativo, conteúdo pornográfico, violência, pegadinha, nada que vai degradar alguém ele compartilha. Ele acredita que se sente motivado a realizar o boca a boca do que constrói.

Ao contrário dos oito respondentes, Maria Raimunda se motiva em realizar comunicação boca a boca negativo quando tem experiencias ruins com as empresas, pois acredita que é uma maneira de avisar as demais pessoas sobre o verdadeiro produto ou atendimento das empresas. Janete também compartilha dessa ideia, informou que se tem um problema no produto ela compartilha porque tem medo que afeta sua família, assim, 
ela compartilha com todos: "rato na coca cola... remédio que faz mal, eu sempre coloco. Sempre com a intenção de informar as pessoas, principalmente os meus, quem me tem no Face”.

JO afirmou que sempre realiza a comunicação negativa, mas não tem evidências em sua página no Facebook. Manuela afirma que o Facebook não é o melhor canal para NWOM, que procura o Procon (Programa de Proteção e Defesa do Consumidor) ou a ouvidoria da empresa para reclamar.

Se tem humor na mensagem o SM afirma que sempre compartilha, não importando a sua relação com a empresa, se teve uma experiencia positiva ou negativa.

Ademir aponta que realiza o NWOM quando quer mostrar sua indignação de assuntos políticos, corrupção que envolve as empresas e o governo.

Tendo em vista a análise das respostas da pesquisa de campo, retoma-se a premissa 1: A relação das pessoas idosas usuárias de internet com marcas ou produtos comprados motiva o boca a boca em meio digital. Sendo positivo quando houver satisfação na relação com a empresa, e negativo quando houver maior insatisfação na relação com a empresa.

Assim, percebe-se que a premissa um é conferida nas respostas de somente alguns respondentes.

\subsubsection{Comunicação ativa}

A) Subcategoria inovação

Para o entrevistado MD a comunicação boca a boa proporciona aprendizado e inovação constante, especialmente para professores, assim como ele: "claro que sim, e o bom do professor é isso, sempre se inovando".

Ao analisar seu perfil, pode-se perceber muitos compartilhamentos de aspectos políticos, mostrando a sua opinião, mostrando seu desejo de influenciar outros e proliferar suas ideias (categoria proliferação de ideias), porém não foi encontrada nenhuma comunicação boca a boca que mostrasse inovação. 


\section{B) Subcategoria ocupação}

A partir do relato da Janete, percebe-se que o boca a boca em meio digital colaborou com a diminuição da solidão: "imagina a gente que antigamente não tinha Face e ficava a tarde toda vendo televisão, filme repetido, programa repetido. Chegava uma hora que eu falava meu Deus, o que eu to fazendo aqui? [...] e o face mudou isso. Sempre ativa!”.

Os idosos vêm na internet e na rede social Facebook uma solução para a solidão que pode ocorrer em alguns momentos. Por esse motivo, eles acreditam que com a realização da comunicação boca a boca eles se aproximam das pessoas.

Ao analisar o compartilhamento da Janete, pode-se perceber complementarmente que ela é um pouco mais ativa que os demais idosos entrevistados, tendo em média a realização de cinco comunicações boca a boca por dia, porém houve dias em que ela compartilhou doze mensagens.

\section{C) Subcategoria social}

Todos os respondentes afirmaram que a grande motivação para a realização da comunicação boca a boca em meio digital são as relações sociais que ela proporciona. Os respondentes afirmam que manter-se em comunicação ativa, ter frequentemente contato com familiares e amigos é o grande moti para o compartilhamento.

O compartilhamento gera para os idosos entrevistados aprendizados, seja com os conteúdos das mensagens, seja com a utilização da rede social ou da internet de modo geral. Em sua entrevista, Maria Vicentina afirmou: "se você está aprendendo, é o que eu falei quando você está aprendendo, se é uma coisa legal, eu acho que vale a pena compartilhar. Então, eu sempre compartilho coisas que eu acho que são interessantes, que são para crescer". Complementarmente, Maria Raimunda declara: "sim, me motiva, me incentiva a mandar, colabora com a memória. Para minha cunhada que não trabalha é maravilhoso".

Para Manuela a mensagem tem que ter relação com os interesses do receptor: "não vou forçar para mudar a cabeça do receptor porque me tornarei antiquada. A informação importante para meu remetente eu compartilho". Assim, Manuela aponta em seu discurso que pretende manter uma rede de relações ativa, manter-se em comunicação ativa.

Quando os entrevistados foram questionados sobre a motivação para a comunicação boca a boca estar relacionada à diminuição do isolamento digital do idoso, 
proporcionando novos aprendizados e colaborando com a tomada de decisão, Maria Vicentina, AV, Manuela e Ademir disseram não concordar com isso. Esses respondentes informaram que o idoso que é isolado digitalmente, mesmo que receba estímulos, não irá aprender a realizar a comunicação boca a boa em meio digital e não irá diminuir seu isolamento digital. Todos os outros respondestes sente-se motivados em realizar o boca a boa em meio digital com idosos para que o isolamento digital diminua.

Sobre a influência na tomada de decisão para o idoso, este item é uma motivação para a realização da comunicação boca a boca de cinco respondentes: Maria Vicentina, Janete, MD, JO, IM. Muito embora não seja uma motivação para o respondente SM, ele acredita que a comunicação boca a boca em meio digital pode colaborar com a tomada de decisão do idoso, mas que ele não tem o desejo de interferir nas decisões deles.

Maria Vicentina acredita que o idoso seja mais vulnerável, que ele precisa de fato de ajuda para tomar suas decisões e entende esse item como uma motivação. Ela alerta que ele tem mais dificuldade em analisar o que é bom ou ruim do que lhe é indicado, e por isso as indicações devem ser feitas de forma criteriosa.

Os respondentes Janete, MD, AV, JO, Manuela e IM acreditam que a comunicação boca a boca em meio digital pode interferir na tomada de decisão dos jovens. Isso porque eles acreditam que o jovem está na internet para formar sua opinião, comportamento esse na opinião dos respondentes AV e Manuela que não condiz com o dos idosos.

Tendo essa análise, pode-se responder as premissas 6 e 7:

Premissa 6 - A motivação para o compartilhamento de mensagem se dá devido a necessidade de interação digital, social e aprendizado constante.

Essa motivação foi verificada na análise das entrevistas de todos os respondentes que foram entrevistados.

Premissa 7: $O$ idoso realiza a comunicação boca a boca motivado pelo desejo de inserir outros idosos socialmente e ajudá-los na tomada de decisão.

Essa premissa foi verificada em algumas das entrevistas realizadas. 


\subsubsection{Descontração}

A) Subcategoria leveza

A questão da leveza foi citada pela entrevistada Manuela. Ela acredita que uma das suas principais motivações para a realização da comunicação boca a boca é a ideia de relaxamento e descontração.

Para ela, nem toda comunicação boca a boca precisa ser de apreensão, aprendizado ou imposição.

De acordo com a Manuela:

Poemas para trazer um pouco de leveza. Engraçado, também acho que alegria e humor também trazem leveza, mas eu não compartilho humor. Acho que porque o humor que vem é um humor pesado, crítico. Então, compartilho mais poesia e reflexão, coisas filosóficas. Detesto o compartilhamento de doença, que expõe a doença, bicho massacrado, agressão aos velhos. A reflexão eu compartilho, mas explícito não, detesto. Acho ofensivo, agride as pessoas e que não agrega. Me parece muito aqueles jornais, que se você torcer sai sangue. É o chamar pela apelação, e no Face tem isso também e não acho legal.

Assim, pode-se perceber que a questão da poesia para a entrevistada traz a leveza que ela almeja com a realização da comunicação boca a boca, o que não foi citado por nenhum outro entrevistado.

\subsubsection{Diversão}

A) Subcategoria humor

O humor foi citado como uma motivação para um dos respondentes, o SM, que tem esse item como uma das suas motivações. Ele aponta que não tem o interesse de discutir ideias mais sérias como política no Facebook, ele tem a necessidade de aceitação também como motivação, o que impede ele de entender a proliferação de ideias como uma motivação.

O respondente afirma já ter tido problemas de discussões com outros usuários do Fabebook por ter opinião contrária a deles. SM aponta que não se sente mais confortável tendo que discutir com pessoas que não concordam com suas opiniões. 
Figura 13 - Humor - SM

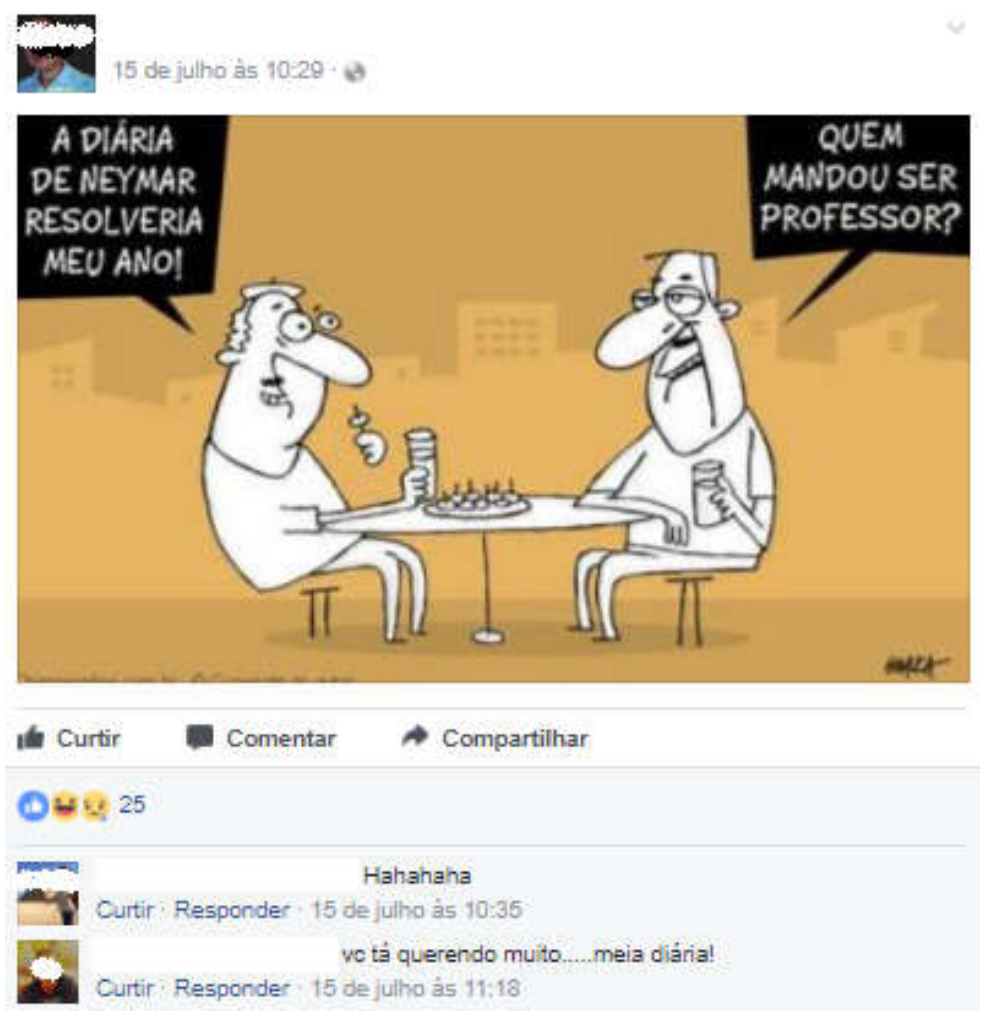

Fonte: www.facebook.com.br

\subsubsection{Educação}

A) Subcategoria aprendizado

Os respondentes afirmam que o conteúdo da mensagem não tem importância, ele pode variar. A motivação é realizar a comunicação boca a boca com o que é importante para o receptor, ou seja, os assuntos devem ser de interesse dos receptores.

Como cada indivíduo pode ter interesses variados e eles não necessariamente são iguais aos interesses dos outros indivíduos, os respondentes afirmaram que o conteúdo das mensagens varia muito. $\mathrm{O}$ que importa é que contribua de alguma forma para o receptor.

Com esse comportamento os respondentes informaram acreditar que estão aprendendo sobre novas coisas e estão colaborando também com o aprendizado do 
receptor das mensagens. Para Janete, se ela está realizando a comunicação boca a boca com o assunto religioso, ela está ensinando a ter fé e ser otimista.

AV acredita que todo ensinamento corrobora de alguma forma com a tomada de decisão do jovem, por esse motivo, ele entende o aprendizado como uma motivação para a realização do boca a boca em meio digital.

B) Subcategoria atualidade

O entrevistado SM realiza a comunicação boca a boca movido pela motivação de estar atualizado: "novidade, detesto mandar coisas que não sejam novidade, da mesma forma que detesto receber posts antigos".

Para ele, o recebimento das coisas atuais traz aprendizado e não deixa o ato de compartilhar monótono.

O respondente mostrou pouca paciência para lidar com situações de conflitos geradas por divergência de opiniões. Ao analisar o Facebook do respondente, percebe-se que a sua realização de comunicação boca a boca em meio digital condiz com a informação que ele passou durante a entrevista.

\subsubsection{Estímulo emocional}

\section{A) Subcategoria emocional}

O que emociona o emissor é importante para a respondente Maria Vicentina, ela acredita que trazer emoção para a vida dela é importante: "bom, eu acho que normalmente quando você recebe uma mensagem que emociona também é um aprendizado. [...] fala de repente de filho, de família, eu gosto de passar para as pessoas porque eu quero que elas sintam as mesmas emoções que eu estou sentindo.

AV também é motivado em realizar a comunicação boca a boca quando provoca alguma emoção, mas nesse caso, no receptor. 
B) Subcategoria satisfação

O compartilhamento em meio digital para JO e IM gera satisfação pessoal, ou seja, as respondentes sentem-se bem em realizar a comunicação boca a boca porque os receptores as entendem como importantes.

JO afirma: "não é por orgulho, mas as pessoas dizem que o meu compartilhamento faz bem, que eu escuto as pessoas, e isso também faz bem para elas.

No caso da IM a satisfação pessoal ocorre porque ela recebe retornos voltados para a parte profissional, as pessoas que recebem a sua comunicação boca a boca elogiam seus trabalhos e fazem encomendas.

\subsubsection{Proliferação de ideia}

A) Subcategoria imposição

Essa subcategoria foi apontada pelos respondentes MD e Manuela. Esses respondentes identificam como motivação a necessidade de proliferar ideias e impor ideias que eles têm sobre vários assuntos. Acreditam que se é um conhecimento de se ter, eles compartilham para que todos pensem como eles.

Para MD a ideia de difusão do assunto como ele pensa é importante: "procuro difundir o que é importante para mim, para difundir o assunto, as ideias que a gente tem. [...] Porque quanto mais diversidade nos conteúdos mais pessoas você vai atingir [...]se tiver uma pessoa com a mesma ideia que a minha eu já consegui atingir meu objetivo”.

Em alguns trechos da entrevista da Manuela também pode-se perceber que o convencimento é uma motivação para a realização da comunicação boca a boca:

A questão da mulher, da democracia, das coisas que são aberrações no meu ponto de vista. A questão do que é preconceito para mulher, homossexual, negro. Quero que as outras pessoas percebam isso. Quando eu compartilho eu sempre coloco alguma coisa como vejam que absurdo, pode acontecer isso?

A entrevistada gosta do compartilhamento no Facebook porque ele é muito dinâmico, então ele pode advertir diversos receptores de assuntos que são importantes para ela todos os dias: "então quem sabe uma hora a pessoa está mais sensível, mais aberta para aquilo e quem sabe ela reflete sobre o assunto. As pessoas acham o Face superficial, 
mas o superficial contínuo pode provocar o aprofundamento". Percebe-se assim, a necessidade proliferar sua ideia com a comunicação boca a boca em meio digital.

\subsection{Análise qualitativa de conteúdo das entrevistas baseada no referencial teórico}

Nesse tópico são comparados os achados da pesquisa de campo com o conteúdo descrito na literatura. São apresentadas três tabelas: a primeira tabela mostra o que foi descrito na literatura e verificado na pesquisa de campo, a segunda descrevendo o que foi descrito na literatura e não foi encontrado na pesquisa de campo e a terceira o que não foi descrito na literatura, mas verificado na pesquisa de campo.

\section{Tabela 9 - Descrito na literatura e verificado na pesquisa de campo}

\begin{tabular}{|c|c|c|c|}
\hline & \\
\hline & Categoria & Descrição & Literatura \\
\hline \multirow{13}{*}{$\begin{array}{l}\text { Descrito na } \\
\text { literatura e } \\
\text { verificado na } \\
\text { pesquisa de } \\
\text { campo }\end{array}$} & Afeição/altruísmo & A necessidade de ser altruísta & $\begin{array}{c}\text { Ho e Dempsey, (2010); Schutz, (1966); } \\
\text { Price et al.., (1995); Dichter (1966); Phelps } \\
\text { et al., (2004) ; Sundaram et al., (1998); } \\
\text { Hennig-Thurau et al., (2004) }\end{array}$ \\
\hline & Afeição/altruísmo & Relacionamento satisfatório & Ho e Dempsey, (2010); Schutz, (1966) \\
\hline & Afeição/altruísmo & $\begin{array}{c}\text { Acolhimento e envolvimento } \\
\text { emocional }\end{array}$ & $\begin{array}{l}\text { Ho e Dempsey, (2010); Schutz, (1966); } \\
\text { Price et al., (1995) }\end{array}$ \\
\hline & Afeição/altruísmo & $\begin{array}{l}\text { Apoio na tomada de decisão do } \\
\text { idoso }\end{array}$ & $\begin{array}{l}\text { Phillips e Sternthal (1977); East et al. } \\
\text { (2014) }\end{array}$ \\
\hline & $\begin{array}{l}\text { Boca a boca } \\
\text { negativo }\end{array}$ & $\begin{array}{c}\text { Gera boca a boca negativo } \\
\text { quando há insatisfação com a } \\
\text { marca }\end{array}$ & Esteves et al., (2015) \\
\hline & $\begin{array}{c}\text { Boca a boca } \\
\text { positivo }\end{array}$ & $\begin{array}{c}\text { Gera boca a boca positivo quando } \\
\text { há satisfação com a marca }\end{array}$ & Oiver, (1980); Swan e Oliver, (1989) \\
\hline & $\begin{array}{l}\text { Comunicação } \\
\text { ativa }\end{array}$ & $\begin{array}{c}\text { Informações úteis contidas na } \\
\text { mensagem }\end{array}$ & $\begin{array}{l}\text { Berger e Milkman (2012); Kasabov, } \\
\text { (2016); Sundaram et al. (1998) }\end{array}$ \\
\hline & $\begin{array}{l}\text { Comunicação } \\
\text { ativa }\end{array}$ & $\begin{array}{l}\text { Senso de autoestima e } \\
\text { socialização }\end{array}$ & Tang et al. (2016) \\
\hline & $\begin{array}{l}\text { Comunicação } \\
\text { ativa }\end{array}$ & $\begin{array}{c}\text { Manter-se em comunicação ativa } \\
\text { e aprender constantemente }\end{array}$ & Peral et al.,(2015); East et al., (2014) \\
\hline & Controle & $\begin{array}{c}\text { Necessidade de crescimento } \\
\text { pessoal }\end{array}$ & Ho e Dempsey, (2010); Schutz, (1966) \\
\hline & Controle & $\begin{array}{l}\text { Sentimento de competência, } \\
\text { influência, realização }\end{array}$ & Ho e Dempsey, (2010); Schutz, (1966) \\
\hline & Controle & $\begin{array}{c}\text { Fazer a diferença em seu } \\
\text { ambiente social e dizer como isso } \\
\text { acontece }\end{array}$ & Ho e Dempsey, (2010); Schutz, (1966) \\
\hline & Diversão & $\begin{array}{l}\text { Componente de diversão da } \\
\text { mensagem }\end{array}$ & Bentivegna (2002) \\
\hline
\end{tabular}




\begin{tabular}{|c|c|c|}
\hline Educação & $\begin{array}{l}\text { Apoio na tomada de decisão do } \\
\text { jovem }\end{array}$ & Arndt, (1967) \\
\hline Educação & $\begin{array}{l}\text { Diminuição do isolamento digital } \\
\text { e apoio à tomada de decisão do } \\
\text { remetente }\end{array}$ & $\begin{array}{l}\text { East et al., (2014); Arndt, (1967); } \\
\text { Labsomboonsiri et al. (2017) }\end{array}$ \\
\hline Inclusão & $\begin{array}{c}\text { A necessidade de fazer parte de } \\
\text { um grupo }\end{array}$ & $\begin{array}{c}\text { Ho e Dempsey, (2010); Schutz, (1966); } \\
\text { Tang et al., (2016) }\end{array}$ \\
\hline Inclusão & $\begin{array}{l}\text { Reconhecimento como } \\
\text { participante em uma ação }\end{array}$ & $\begin{array}{c}\text { Ho e Dempsey, (2010); Schutz, (1966); } \\
\text { Tang et al., (2016) }\end{array}$ \\
\hline Individualidade & $\begin{array}{l}\text { Compartilhamento de coisas } \\
\text { relacionadas a autoimagem }\end{array}$ & $\begin{array}{c}\text { Ho e Dempsey, (2010); Dichter, (1966); } \\
\text { Chan e Misra, (1990); Sundaram et al. } \\
\text { (1998) }\end{array}$ \\
\hline Individualidade & Auto aperfeiçoamento & Sundaram et al. (1998) \\
\hline Individualidade & $\begin{array}{l}\text { Compartilha mais produtos e } \\
\text { experiências que fortalecem a } \\
\text { imagem pessoal que quer } \\
\text { projetar }\end{array}$ & Chung e Darke (2006) \\
\hline Individualidade & $\begin{array}{c}\text { Senso de identidade para ganhar } \\
\text { atenção e status }\end{array}$ & Dichter (1966) \\
\hline Individualidade & $\begin{array}{l}\text { Se diferenciar dos } \\
\text { outros/destaque }\end{array}$ & $\begin{array}{l}\text { Ho e Dempsey, (2010); Schutz, (1966); } \\
\text { Dichter, (1966); Chan e Misra, (1990) }\end{array}$ \\
\hline
\end{tabular}

Fonte: elaborado pela autora

As motivações discutidas por Schutz (1966) que afirmavam que os seres humanos se comunicam e se relacionam para satisfazer necessidades pessoais de acordo com os três eixos (inclusão, afeição e controle), foram desenvolvidas por Ho e Dempsey (2010), com a hipótese de que os usuários que consomem mais conteúdo na internet e os que possuem um nível de curiosidade mais elevada tenham a probabilidade de compartilhar mais. Os resultados apontados por Ho e Dempsey (2010) mostram que os mais curiosos não têm maior propensão ao compartilhamento, mas que os usuários que consomem mais conteúdo na internet realmente realizam mais o compartilhamento de conteúdo.

Das motivações para o compartilhamento Ho e Dempsey (2010) apontam que a inclusão, individualidade e afeição/altruísmo têm influência direta com o ato de compartilhar conteúdo em meio digital. Porém, controle não tem influência direta com o ato de compartilhar conteúdo em meio digital.

Conforme detalhado na análise qualitativa de conteúdo, as quatro categorias definidas a priori com base na literatura (inclusão, individualidade, afeição/altruísmo e controle) foram verificadas na pesquisa de campo, mas parcialmente porque elas não foram verificadas em todos respondentes.

A verificação parcial da individualidade é consistente com a teoria de Chan e Misra (1990) que sugerem que os líderes de opinião/especialistas são indivíduos dispostos a se 
individualizar publicamente compartilhando suas opiniões com os outros. Ho e Dempsey (2010) acreditam que os especialistas estão dispostos a disseminar conteúdo na internet com outros usuários como forma de mostrar sua singularidade.

Dichter (1966) aponta que a realização do compartilhamento pelos altruístas está baseada em amor e afeição, sem interesse pessoal, o que foi conferido nas entrevistas e nas postagens observadas em quase todos os respondentes. Phelps et al. (2004); Sundaram et al. (1998); Hennig-Thurau et al. (2004) também apontam que muitas pessoas são motivadas pelo altruísmo para realização da comunicação boca a boca em meio digital.

Autores como Gaber e Wright (2014) apontam que a internet é utilizada para manter contato com outros e desenvolver novos relacionamentos e essa característica foi fortemente apontada pelos respondentes.

Outras motivações foram verificadas na pesquisa de campo como as estabelecidas nas categorias educação, diversão, comunicação ativa e boca a boca negativo e positivo.

Tabela 10 - Descrito na literatura, mas não verificado na pesquisa de campo

\begin{tabular}{c|c|c|c|}
\cline { 2 - 4 } & Categoria & Descrição & Literatura \\
\cline { 2 - 4 } & Não se aplica & $\begin{array}{c}\text { Incentivos, recompensa econômica e } \\
\text { reciprocidade }\end{array}$ & $\begin{array}{c}\text { Tang et al. (2016); } \\
\text { Bentivegna, (2002) }\end{array}$ \\
\cline { 2 - 4 } $\begin{array}{c}\text { Descrito na literatura, } \\
\text { mas não verificado na } \\
\text { pesquisa de campo }\end{array}$ & Não se aplica & Familiaridade com a marca da empresa & Bentivegna (2002) \\
\cline { 2 - 4 } & Não se aplica & $\begin{array}{c}\text { Desenvolvimento de uma massa crítica de } \\
\text { amplificadores da mensagem }\end{array}$ & Bentivegna (2002) \\
\cline { 2 - 4 } & Não se aplica & Baixa complexidade da mensagem & Bentivegna (2002) \\
\cline { 2 - 4 } & Não se aplica & Ineditismo da ação de marketing viral & Bentivegna (2002) \\
\hline
\end{tabular}

Fonte: elaborado pela autora

A tabela acima aponta que itens descritos pelos autores Tang et al. (2016) e Bentivegna (2002) não foram considerados como importantes para o comportamento do usuário de internet idoso para realização da comunicação boca a boca em meio digital.

Os incentivos e recompensas econômicas não são consideradas pelos idosos entrevistados, pois eles consideram que muitas mensagens desse gênero são golpes. Eles acreditam não estar seguros suficientemente para compreender se tais mensagens são ou 
não fraudulentas, evitando assim o seu compartilhamento. Esse achado contraria os autores Tang et al. (2016) e Bentivegna (2002). Para Bentivegna (2002), a aceleração da difusão da mensagem virtual pode ser também atingida pela oferta de algum tipo de incentivo para a replicação da mensagem

A familiaridade com a marca da empresa foi apontada até como interessante para o recebimento da mensagem, mas não como um item motivador para a realização da comunicação boca a boca.

Os outros itens apontados por Bentivegna (2002) como desenvolvimento de uma massa crítica de amplificadores da mensagem, baixa complexidade da mensagem, ineditismo da ação de marketing viral não foram citados pelos entrevistados como importantes.

Tabela 11 - Não descrito na literatura, mas verificado na pesquisa de campo

\begin{tabular}{c|c|c|c|}
\cline { 2 - 4 } & Categoria & Descrição & Literatura \\
\cline { 2 - 4 } & Análise de perfil & $\begin{array}{c}\text { Identificar o comportamento do } \\
\text { receptor }\end{array}$ & não se aplica \\
\cline { 2 - 4 } $\begin{array}{c}\text { Não descrito na } \\
\text { literatura, mas } \\
\text { verificado na } \\
\text { pesquisa de campo }\end{array}$ & Comunicação ativa & Ocupação & não se aplica \\
\cline { 2 - 4 } & Descontração & Relaxamento & não se aplica \\
\cline { 2 - 4 } & Educação & Ensina o emissor e o receptor & não se aplica \\
\cline { 2 - 4 } & Estímulo emoção & Atualidade & não se aplica \\
\cline { 2 - 4 } & Estímulo emocion \\
\cline { 2 - 4 } & Proliferação de & Emociona o entrevistado & não se aplica \\
\hline
\end{tabular}

Fonte: elaborado pela autora

Os itens descritos na tabela acima não foram descritos na literatura consultada, mas foram verificados nas respostas durante a pesquisa de campo. Somente um respondente tem motivação a identificação do comportamento do receptor. SM alega que realiza a comunicação boca a boca e analisa o que de fato interessa para cada receptor. Para ele, isso faz com que ele conheça seus contatos mais profundamente, e assim ele passa a saber como lidar com cada um. 
A internet é para muitos dos idosos entrevistados uma forma de ocupação. Eles alegaram que no passado ficavam desocupado, ociosos, e por meio da comunicação boca a boca ocuparam seus tempos.

O compartilhamento de algumas coisas como poemas, conforme citado por Manuela, traz relaxamento e descontração, porém isso não foi apontado por nenhum outro respondente.

Todos respondentes afirmaram que a realização da comunicação boca a boca proporciona o aprendizado, os mantêm atualizados. Apesar de não terem sidos citados na literatura pesquisada, esses itens foram descritos como importantes.

Outros itens como emociona o entrevistado, satisfação pessoal do emissor, imposição das ideias do emissor foram também apontados como motivações para a realização da comunicação boca a boca em meio digital e foram detalhados na análise qualitativa de conteúdo.

Com as análises percebe-se que o modelo de Ho e Dempsey (2010) foi verificado na pesquisa de campo parcialmente, ou seja, inclusão, individualidade, afeição/altruísmo e controle não foram consideradas motivações por todos os respondentes. A grande maioria das motivações encontradas foram descritas na literatura.

As motivações descritas na literatura que não foram encontradas na pesquisa de campo realizada para este estudo podem estar relacionadas a outros segmentos ou perfis de respondentes. Porém, entende-se que incentivos e recompensas não motivam os respondentes de forma unânime. As outras motivações propostas por Bentivegna (2002) como familiaridade com a marca da empresa, desenvolvimento de uma massa crítica de amplificadores da mensagem, baixa complexidade da mensagem e ineditismo da ação de marketing viral não foram citados pelos respondentes.

As motivações verificadas na pesquisa de campo que não foram descritas na literatura consultada como identificação do comportamento do receptor, ocupação, relaxamento, ensinamento, atualidade, emoção, satisfação pessoal e imposição de ideias podem proporcionar novas oportunidades para as empresas se forem exploradas em perfis como os respondentes deste estudo. 


\section{CONSIDERAÇÕES FINAIS}

Esse estudo teve como objetivo a compreensão das motivações para o boca a boca em meio digital dos usuários de internet idosos. Para responder à pergunta de pesquisa $\mathrm{e}$ alcançar o objetivo supracitado, foi realizada uma revisão da literatura dos assuntos pertinentes ao objetivo, foram realizadas entrevistas em profundidade com idosos usuários de internet e seus perfis no Facebook foram observados.

A revisão da literatura possibilitou a formação de conhecimento base sobre internet, comunicação boca a boca e idoso. Percebe-se que, apesar dos idosos ainda não estarem tão conectados à internet como os jovens, é crescente o número de idosos que acessa a internet e que deseja se socializar digitalmente. O crescente número de idosos em todo o mundo também permite perceber a possibilidade do aumento no número de usuários idosos na internet.

A revisão da literatura também permitiu perceber que existem algumas barreiras para a socialização digital dos idosos, porém, algumas ações, como programas elaborados pelo governo, foram criadas para que essas barreiras sejam extintas um dia.

Percebeu-se com a revisão da literatura que a comunicação boca a boca em meio digital permite o desenvolvimento cognitivo relacionado a linguagem, atenção, memória e raciocínio do idoso, o que é muito positivo na velhice.

As entrevistas com dez idosos usuários da internet possibilitaram a compreensão das motivações para o boca a boca em meio digital, apontando os perfis de comportamento dos entrevistados. Foram definidas quatro categorias a priori estabelecidas com base em Ho e Dempsey (2010). As motivações do modelo de Ho e Dempsey (2010) - inclusão, individualidade, afeição/altruísmo e controle - foram verificadas parcialmente na pesquisa de campo com segmento dos idosos usuários da internet.

Sobre a inclusão, percebeu-se que a maioria da comunicação boca a boca dos entrevistados traz aspectos que apontam como eles agem e pensam. Apesar da individualidade ser indicada como motivação para alguns dos entrevistados, o Facebook não é normalmente usado com a intenção do entrevistado ser aceito. Muitos apontam que não fazem compartilhamentos da sua autoimagem, mas na realidade os fazem. Ainda na categoria individualidade, sobre a subcategoria "destaque", pode-se considerar que os entrevistados não buscam destaque, mas se conseguissem mais destaque com o boca a boca em meio digital, fariam mais compartilhamentos. Percebeu-se que essas são pessoas 
que buscam a inclusão com compartilhamentos que apontam seus modos de agir e pensar, assim, o destaque tem o foco na inclusão.

A afeição/altruísmo é uma motivação que deve ser fortemente considerada por ser importante para oito dos dez respondentes. A categoria controle recebeu destaque na subcategoria "objetivo pessoal", mas isso ocorreu porque oito dos respondentes consideram um objetivo pessoal a realização do altruísmo.

Além das motivações estabelecidas por Ho e Dempesey (2010), outras novas motivações foram verificadas e categorizadas nesse estudo: boca a boca negativo e positivo, comunicação ativa, descontração, diversão, análise de perfil, educação, estímulo emocional e proliferação de ideia.

Com esse estudo, pôde-se compreender que a internet e a rede social Facebook são utilizadas para manter contato com outros, realizar novas relações e reatar relações que haviam se perdido.

Em termos de contribuição teórica, primeiramente pôde-se compreender o comportamento dos entrevistados, que fazem parte do segmento dos idosos, segmento esse que não possuía estudos como este até então. Em segundo lugar, pôde-se compreender que o aprendizado e a comunicação ativa são fortes motivações para a realização da comunicação boca a boca para os entrevistados. Outros aspectos como afeição/altruísmo e a identificação da autoimagem são outras motivações apontadas como fundamentais por oito dos dez respondentes para que haja o compartilhamento de mensagens. Esses resultados sugerem que os respondentes esperam que seus comportamentos sejam interpretados pelos receptores como altruístas, e que marquem sua individualidade e distinção dos demais. Assim, o framework abaixo aponta os principais propósitos e as principais motivações para a realização da comunicação boca a aboca em meio digital para os idosos entrevistados. 
Figura 14 - Principais dimensões das motivações para eWOM dos usuários idosos da internet

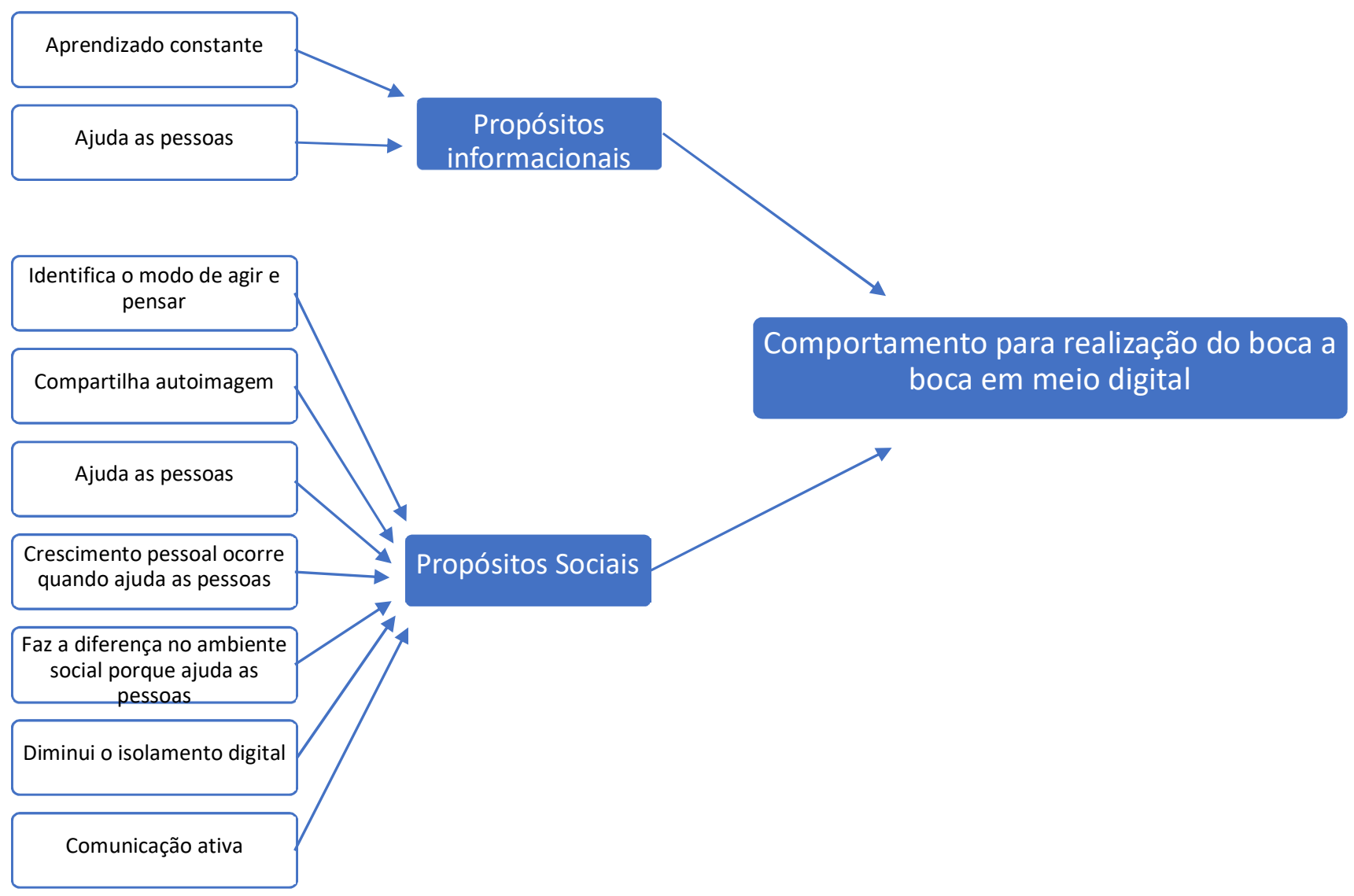

Fonte: elaborado pela autora

Considerando, finalmente, de forma a contribuir para a ampliação do conhecimento no campo de administração/marketing, especificamente na área de comunicação em meio digital, este estudo cruzou dados sobre internet, idosos e comunicação boca a boca, compreendendo as principais motivações para os respondentes idosos usuários da internet participantes da pesquisa de campo. 


\section{LIMITAÇÕES DA PESQUISA E SUGESTÕES PARA ESTUDOS FUTUROS}

As principais limitações dessa pesquisa referem-se ao caráter qualitativo exploratório, que não permite promover generalizações, dado o caráter do grupo estudado e da forma como os dados serão coletados (ZIKMUND, 2006; MALHOTRA, 2011). Na pesquisa qualitativa a coleta de dados utiliza, normalmente, grupos pequenos, dados não numéricos, e assim, a generalização não pode ser realizada para toda a população. Porém, a pesquisadora poderá fazer inferências de um cenário para outros similares. De acordo com Collis e Hussey (2005, p. 64), a confiabilidade não é tão relevante quanto a validade: "não é importante se mensurações qualitativas são confiáveis no sentido positivista, mas se observações e interpretações semelhantes podem ser feitas em diferentes ocasiões e/ou por diferentes observadores". Sobre a validade, os autores informam que existem principais modos de garanti-las: a validade de face, que é simplesmente garantir que os testes e mensurações usados pela pesquisadora foram corretamente empregados para mensurar e representar o fenômeno em estudo. E a validade de construto, baseada nos construtos hipotéticos, que são fenômenos não observáveis - ansiedade, motivação, satisfação, etc - que explicam os fenômenos observáveis segundo a sociologia. Como exemplo, para Martins (2012), uma pessoa nervosa antes de uma entrevista pode suar e tremer: o que se observa não é a ansiedade, mas uma manifestação dela. A validade de construto de uma pesquisa qualitativa, portanto, é a capacidade de os resultados poderem ser explicados pelos construtos, por isso, que inferências para outros cenários poderão ser feitas.

Outro ponto a ser levado em consideração é que a escolha dos respondentes para as entrevistas pode ser considerada como outra limitação por todos serem pertencentes à cidade de São Paulo. Apesar de haver um motivo significativo para tal escolha, dado que essa cidade é onde se concentra a maior quantidade de pessoas com acesso à internet no

Brasil, podem existir influências específicas dessa cidade que irão interferir nos resultados.

O fato de se definir um protocolo de pesquisa e de se utilizar a observação causa uma redução no viés do entrevistador, mas não o elimina totalmente. Assim, mesmo com um roteiro semiestruturado, com parte da análise realizada durante a coleta das informações na entrevista, o viés do entrevistador pode interferir, mesmo que de forma diminuída nos resultados. 
A idade cronológica (número de anos vividos) pode ser um item cada vez mais irrelevante para a segmentação, assim as características comportamentais e o estilo de vida têm recebido maior atenção (SZMIGIN e CARRIGAN, 2001). Assim, estudos quantitativos, em que haja a segmentação de idosos pelo estilo de vida traria alguns insigths para a academia e empresas.

Para futuros trabalhos acadêmicos, recomenda-se a realização de um estudo descritivo que permita mensurar o real impacto de cada uma das motivações dos idosos apresentadas no sucesso de ações de marketing boca a boca em meio digital.

Dada a quantidade de informações apresentadas neste estudo, não se objetiva esgotar as análises sobre o tema. Pretende-se, na realidade, fornecer um conjunto sistematizado de informações que sirvam de elementos a serem retomados por pesquisadores e estudiosos do assunto, possibilitando ampliar as discussões sobre as principais questões relativas à comunicação boca a boca para idosos. 


\section{REFERÊNCIAS}

Aaker, D. A.; Kumar, V.; Day, G. S. (2001). Pesquisa de marketing. São Paulo: Atlas.

Adler, P. A.; Adler, P. (1998).Observational techniques, in N. Denzin and Y. S. Lincoln (eds), Collecting and Interpreting Qualitative Materials. London: Sage. Pp. 79-110.

Agudo, S.; Pascual, M. A.; Oviedo, J. F. (2012). Uses of Digital Tools among the Elderly. Comunicar, n. 39, v. XX, Scientific Journal of Media Education; pages 193-201.

Almeida, M. I. S.; Coelho, R. L. F.; Tete, M. F. (2011). Perspectiva evolutiva do Marketing Viral: um Ensaio sobre sua fundamentação teórica e alternativas para futuros trabalhos. XXXV Encontro da ANPAD. Rio de Janeiro/RJ - 4 a 7 setembro.

Ala-Mutka, K., Malanowski, N., Punie, Y., \& Cabrera, M. (2008). Active Ageing and the Potential of ICT for Learning. Institute for Prospective Technological Studies (IPTS). Joint Research Centre (JRC), European Communities.

Amaral, S. A. (2004). Marketing da informação na internet: ações de promoção. Campo Grande: Ed. Uniderp, 330p.

Amezcua, B.; Quintanilla, C. (2016). When eWOM becomes cynical. International Journal of Consumer Studies 40 (2016) 290-298.

Andrade, J.; Toledo, A. C.; Marinho, M. T. (2013). Uma reflexão crítica sobre o buzz marketing e suas implicações éticas como estratégia de comunicação de marketing. Cadernos de Comunicação, v. 17, n. 1, p. 187209, jan./jun.

Andrade, J.; Mazzon, J.; Katz, S. (2006). Você viu o vídeo do Ronaldinho? Uma reflexão a respeito da associação entre marcas e celebridades e o uso do marketing viral como ferramenta de comunicação de marketing. In: encontro da anpad, $30^{\circ}$.

Andrade, J.; Mazzon, J.; Katz, S. (2006b). Boca a boca Eletrônico: explorando e integrando conceitos de marketing viral, buzz marketing e word-of-mouse. In: 
ENCONTRO DE MARKETING DA ANPAD, Rio de Janeiro. Anais... Rio de Janeiro: Anpad.

Arndt, J. (1967). Role of product-related conversations in the diffusion of a new product. Journal of Marketing Research, 4 (3), 291-295.

Barbosa, L. H. L. Jr.; Silva, J. O.; Gondim, G. B.; Brandão, J. M. F. (2015). Ferramentas de comunicação online na hotelaria: Um estudo das empresas hoteleiras associadas a ABIH-RN. Revista Eletrônica Gestão e Serviços, Rio Grande do Norte, v. 6, n. 1, p.11351149.

Bardin, L. (2007). Análise de conteúdo. 4 ed. Lisboa: Edições 70.

Barger, C. (2013). O estrategista em mídias sociais. Tradução: Sieben Gruppe. São Paulo: DVS.

Barichello, E. M. M. R. B.; Oliveira, C. C. (2010). O Marketing viral como estratégia publicitária nas novas ambiências midiáticas. Em Questão, Porto Alegre, v. 16, n. 1, p.2944, jan/jun.

Barroso, C. L.; Abad, M. V.; Valle, M. S. (2015). Internet and the Elderly: Enhancing Active Ageing. Comunicar, n. 45, v. XXIII, Media Education Research Journal.

Bass, F. M. (1969). A New Product Growth Model for Consumer Durables. Management Science, v. 15, n. 5, p. 215-227.

Belch, G. E.; Belch, M. A. (2008). Propaganda e promoção: uma perspectiva da comunicação integrada de marketing. São Paulo: McGrawHill.

Bentivegna, F. J. (2002). Fatores de impacto no sucesso do marketing boca a boca online. Revista de administração de empresas. São Paulo, v. 42, nº 1, p. 79-87, jan/mar.

Bergman, M. (2001). The deep web: surfacing hidden value, white paper, The journal of electronic publishing. 
Berger, J. ; Milkman, K. (2012). What makes online content viral? Journal of Marketing Research, 49 (2), 192-205.

Bertocchi, D. (2006). A narrativa jornalística no ciberespaço: transformações conceitos e questões. Dissertação de mestrado. Universidade do Minho, Instituto de Ciências Sociais.

Bone, P. F. (1992). Determinants of word-of-mouth communications during product consumption. Advances in Consumer Research. Vol. 19, p. 579-583.

Brynjolfsson, E.; Hitt, L. M. (2000). Beyond computation: information technology, Organizational Transformation and Business Performance. Journal of Economic Perspectives, Vol. 14 No. 4, pp. 23-48.

Bruwer, R.; Rudman, R. (2015). Web 3.0: governace, risk and safeguards. The journal of applied business research. May/June. V. 31, N. 3.

Bruyn, A. de; Lilien, G. L. (2008). A multi-stage model of word-of-mouth influence through viral marketing. International Journal of Research in Marketing, 25, $151-163$.

Buttle, F. A. (1998). Word of mouth: understanding and managing referral marketing. Journal of Strategic Marketing, No 6, p. 241-254.

Castro, J. P. (2007), Comunicação de Marketing, Lisboa, Edições Sílabo

CGI.br. (2009). Pesquisa sobre uso das tecnologias da informação e comunicação no Brasil.

Chang, Y. T.; Yu, H.; Lu, H. P. (2015). Persuasive messages, popularity cohesion, and message diffusion in social media marketing. Journal of business Research, 777-782.

Chan, K. K.; Misra, S. (1990). Characteristics of the opinion leader: a new dimension. J Advert;19(3):53-60.

Cheung, C. M. K.; Lee, M. K. O. (2010). A theoretical model intentional social action in online social networks. Decision support systems, 49(1), 24-30.

Chung, C.; Darke, P. (2006). The Consumer as Advocate: Self-relevance, Culture and Word-of-Mouth. Market Letters, 17, 269-279. 
Churchill, G. A.; Peter, J. P. (2000). Marketing: criando valor para clientes. São Paulo: Saraiva.

Collis, J.; Hussey, R. (2005). Pesquisa em administração: um guia prático para alunos de graduação e pós-graduação. 2 ed. Porto Alegre: Bookman.

Comscore - Disponível em: http://asasesp.org.br/terceira.pdf. Acessado em 15 de março de 2017.

Cravens, D. W.; Piercy, N. F. (2007). Marketing estratégico. São Paulo: McGraw-Hill.

Crescitelli, E.; Shimp, T.A. (2012). Comunicação de marketing. São Paulo: Cengage.

Crescitelli, E.; Figueiredo, J. C. B. (2011). O uso de mapas conceituais para ensino de comunicação integrada de marketing. RAD Vol.13, n.3, p.01-24.

Creswell, J. W. (2010). Projeto de pesquisa: métodos qualitativo, quantitativo e misto. 3 ed. - Porto Alegre: Artmed.

Cruz, D.; Fill, C. (2008). Evaluating viral marketing: isolating the key criteria. Marketing Intelligence \& Planning, Vol. 26 Iss 7 pp. $743-758$.

Curran, J.M., \& Lennon, R. (2013). Comparing Younger an Older Social Network Users: An Examination of Attitudes and Intentions. The Journal of American Academy of Business, 19 (1), 28-37.

Dafonte, A. G. (2014). The key elements of viral advertising. From motivation to emotion in the most shared vídeos. Comunicar Journal 43: media prosumers. Vol. 22.

Deci, E. L., and R. M. Ryan. 1987. "The Support of Autonomy and the Control of Behaviour." Journal of Personality and Social Psychology 53 (6): 1024-1037.

Denegri, K. J. (2006) Consumers behaving badly: deviation or innovation? Power struggles on the web. Journal of Consumer Behaviour, 5, 82-94.

Denzin, N. K. (1970). The Research Act. Chicago: Aldine.denz

De Vriesa, L.; Gensler, S.; Leeflang, P. S. H. (2012). Popularity of brand posts on brand fan pages: na investigation of the effects of social media marketing. Journal of interactive marketing. 26(2). 83-91.

Dichter, E. (1966). How word of mouth advertising works. Harvard Business Review, 44 (6), 147-161.

Donaton, S. (2007). Publicidade + entretenimento: Por que estas duas indústrias precisam se unir para garantir a sobrevivência mútua. São Paulo: Cultrix. 
Duhan, D. F.; Johnson, S. D.; Wilcox, J. B.; Harrel, G. D. (1997). Influences on consumer use of word-of-mouth recommendation sources. Journal of the Academy of Marketing Science, v. 25, n. 4, p. 283-295.

East, R.; Uncles, M. D.; Lomax, W. (2014). Hear nothing, do nothing: The role of word of mouth in the decision-making of older consumers. Journal of Marketing Management Vol. 30, Iss. 7-8.

Eastman, J. K.; Iyer, R. (2004). The elderly's uses and attitudes towards the Internet. Journal of Consumer Marketing, Vol. 21 Issue: 3, pp.208-220.

Engel, J. F.; Warshaw, M. R.; Kinnear, T. C.; Reece, B. B. (2000). Promotional strategy: an integrated marketing communication approach. Cincinnati: Pinnaflex.

Esteves, P. S.; Slongo, L. A.; Barcelos, R. H.; Esteves, C. S. (2015). Third-agers on the internet: impacts on word-of-mouth and online purchase intentions. Procedia Economics and Finance. 23. $1607-1612$.

Ewing, M. T.; Stewart, D. B.; Mather, D. R.; Newton, J. D. (2014). How contagious is your virai marketing campaign? A mathematical model for assessing campaign performance. Journal of advertising research. Jar- 54-2-205-216.

Exame. Disponível em: http://exame.abril.com.br/tecnologia/noticias/brasil-e-3o-paisque-mais-compartilha-posts-em-redes-sociais. Acesso em 20 de abril de 2015.

Fazal, S. M.; Lings, I. N.; Mortimer, G.; Neale, L. (2017). How Gratitude Influences Customer Word-Of-Mouth Intentions and Involvement: The Mediating Role of Affective Commitment. Journal of Marketing Theory and Practice. Volume 25, Issue 2, 3, Pages 200-211.

Facebook - disponível em www.facebook.com.br - acessado em junho de 2017.

Fidler, R. (1997). Mediamorphosis: understanding new media. Estados Unidos, Califórnia: Pine Forge Press.

Fourt, L.; Woodlock, J. (1960). Early prediction of market success for new grocery products. The Journal of Marketing, v. 25, n. 2, p. 31-38.

Friedl, J.; Vercic, A. T. (2011). Media preferences of digital natives' internal communication: A pilot study. Public Relations Review 37. 84-86.

Fill, C. (2002). Marketing communications: contexts, strategies, and applications. Harlow: Prentice Hall.

Flick, U. (2004). Uma introdução à pesquisa qualitativa. 2. ed. Porto Alegre: Bookman.

Flick, U. (2009). Qualidade na pesquisa qualitativa. Porto Alegre: Artmed. 
Fritsch, T., Steinke, F. \& Silbermann, L. (2013). Communication in Web 2.0: A Literature Review about Social Network Sites for Elderly People. Proceedings of the IADIS International Conference ICT, Society and Human. Beings.

Galão, F. P; Crescitelli, E. (2015). Planejamento e implantação da comunicação de marketing: uma análise comparativa entre teoria e prática. REGE, São Paulo - SP, Brasil, v. 22 , n. 3 , p. $435-452$, jul./set.

Galão, F. P.; Crescitelli, E.; Baccaro, T. (2011). A. Comunicação Integrada de Marketing: uma Ferramenta do Posicionamento Estratégico? Unopar Científica. Ciências Jurídicas e Empresariais, v. 12, p. 85-91.

Gaber, H. R.; Wright, L. T. (2014). Fast-food advertising in social media. A case study on Facebook in Egypt. Journal of Business and Retail Management Research (JBRMR) Vol. 9 Issue 1

Geargeoura, L.J. (2007). As 1001 faces dos serviços de saúde no Brasil: um mapa exploratório do posicionamento mercadológico nos segmentos de hospitais e de operadoras de Saúde. In: Encontro Anual da Associação Nacional de Programas de PósGraduação em Administração. ENANPAD, Salvador, Anais. Rio de Janeiro: ANPAD.

Gerhardt, T; Silveira, D. (2009). Métodos de pesquisa. Porto Alegre: editora da UFRGS. Disponível em http://www.ufrgs.br/cursopgdr/downloadsSerie/derad005.pdf. Acesso em 01 de junho de 2016.

Gensler, S., Völckner, F., Liu-Thompkins, Y.; Wiertz, C. (2013). Managing brands in the social media environment. Journal of Interactive Marketing, v. 27, n 4, p. 242-256, nov.

Gil, A. C. (2007). Como elaborar projetos de pesquisa. 4 ed. São Paulo: Atlas.

Gill, P.; STEWART, K.; TREASURE E.; CHADWICK, B. (2008). Methods of data collection in qualitative research: interviews and focus groups. In: British Dental Journal, v. 204, p. 291-295.

Gladwell, M. (2002). The Tipping Point: How Little Things Can Make a Big Difference. 1ed. Nova York: Little, Brnwn and Company.

Godoi, C. K.; Mattos, P. L. C. L. (2006). Entrevista qualitativa: instrumento de pesquisa e evento dialógico. In Godoi, C. K. et al. (Org.) Pesquisa qualitativa em estudos organizacionais: paradigmas estratégias e métodos. São Paulo: Saraiva.

Gomes, B. L. T.; Mondo, T. S. (2016). A contribuição das redes sociais na captação de clientes sob a percepção dos gestores hoteleiros. Brazilian Journal of Marketing - BJM Revista Brasileira de Marketing - ReMark Vol. 15, N. 2. Abril/Junho.

Gosh, S. (1998). Making Business Sense of the Internet. Harvard Business Review, p. 126-127, mar/apr.

Goyette, I.; Ricard, L.; Bergeron, J.; Marticotte, F. (2010). e-WOM scale: Word-of-mouth 
measurement scale for e-services context. Canadian Journal of Administrative Sciences, 27, 5-23. doi:10.1002/cjas.129.

Harrison-Walker, L. J. (2001). The measurement of word-of-mouth communications and an investigation of service quality and customer commitment as potential antecedents. Journal of Service Research. Vol. 4, No 1, p. 60-75. August.

Hasan, H.; Linger, H. (2016) Enhancing the wellbeing of the elderly: Social use of digital technologies in aged care, Educational Gerontology, 42:11, 749-757

Hayles, N. K. (1999) How we became posthuman. Chicago: The University of Chicago Press.

Heinrichs, J. H., Lim, J. S.; Lim, K. S. (2011) Influence of social networking site and user access method on social media evaluation. Journal of Consumer Behaviour, 10, 347-355.

Hennig-Thurau, T., Gwinner, K. P., Walsh, G., Gremler, D. D. (2004). Electronic wordof-mouth via consumer-opinion platforms: what motivates consumers to articulate themselves on the internet? Journal of Interactive Marketing, 18(1), 38-52.

Herr, P. M.; Kardes, F. R.; Kim, J. (1991). Effects of word-of-mouth and product-attribute information on persuasion: an accessibility-diagnosticity perspective. Journal of Consumer Research, v. 17, p. 454-462, mar.

Hine, C. (2005). Virtual Methods and the Sociology of Cyber-Social-Scientific Knowledge. In: C.

Hine, C. (2004). Etnografia Virtual. Colección nuevas Tecnologías y Sociedad. Barcelona, Editorial UOC

Hinz, O.; Skiera, B.; Barrot, C.; Becker, J. U. (2011). Seeding strategies for viral marketing: an empirical comparison. Journal of Marketing Vol. 75. November, 55-71.

Ho, J. Y. C.; Dempsey, M. (2010). Viral marketing: Motivations to forward online contente. Journal of Business Research 63. 1000-1006.

Huelves, F. (2009). Buenas prácticas TIC. La alfabetización digital en mayores. Teoría de la Educación, 10(2), 56-77.

Hutter, K.; Hautz, J.; Dennhardt, S.; Füller, J. (2013). The impact of user interactions in social media on brand awareness and purchase intention: the case of MINI on Facebook. Journal of Product \& Brand Management, 22(5/6), 2-2

Ibge - Instituto Brasileiro de Geografia e Estatística (2016). Disponível em: http://biblioteca.ibge.gov.br/visualizacao/livros/liv98579.pdf. Acesso em: 20 de abril de 2017. 
Ibope - Instituto Brasileiro de Opinião Pública e Estatística (2015). Disponível em: http://www.ibope.com.br/pt-br/noticias/Paginas/No-Brasil,-maioria-dos-internautass\%C3\%A3o-mulheres-.aspx. Acesso em: 20 de abril 2015.

Ikeda, A. A. (1997). Estratégias de promoção: a importância da comunicação boca-a-boca em relação a outros instrumentos promocionais. Congresso Anpad - Associação Nacional dos Programas de Pós-Graduação em Administração.

Ikeda, A.A.; Crescitelli, E. (2003). O efeito potencial da comunicação integrada de marketing. Revista Marketing, maio.

Interactive Advertising Bureau (IAB). http://iabbrasil.net/assets/upload/boas_praticas/1457447232.pdf Acessado em 15 de maio de 2016.

Jenkins, H. (2014). Cultura da Conexão: criando valor e significado por meio da mídia propagável / Henry Jenkins, Sam Ford e Joshua Green. Tradução: Patricia Arnaud. São Paulo: Aleph.

Jones, C. (2002). Designing for baby boomers and beyond. Appliance Manufacturer, Vol. 49 No. 11, November, pp. 52-6.

Juncos, O., Pereiro, A.; Facal, D. (2006). Lenguaje y comunicación. In C. triadó \& F. villar (Eds.), Psicología de la vejez. Madrid: Alianza.

Kapferer, J. N. (1993). Boatos: o meio de comunicação mais antigo do mundo. Rio de Janeiro: Forense Universitária.

Kaplan, A. M.; Haenlein, M. (2011). Two hearts in three-quarter time: How to waltz the social media/viral marketing dance. Business Horizons (2011) 54, 253-263.

Kaplan, A. M.; Haenlein, M. (2010). Users of the wolrd, unite! The challenges and opportunities of social media. Business horizons, v. 53, n. 1, p. 59-68, jan.

Karjaluoto, H.; Mustonen, N., Ulkuniemi, P. (2015). The role of digital channels in industrial marketing communications. Journal of Business and Industrial Marketing, 30 (6), pp. 703-710.

Kasabov, E. (2016). Unknwon, surprising, and economically significant: the realities of eletronic word of mouth in chinese social networking sites.

Katz, E.; Lazarsfeld, P. F. (1955). Personal influence -The part played by people in the flow of mass communication. New York: The Free Press.

Keller, K. L. (2001). Mastering the marketing communications mix: micro and macro perspectives on integrated marketing communication programs. Journal of Marketing Management, v. 17, n. 7/8, p. 819-847. 
Kim, A. J.; Ko, E. (2012). Do social media marketing activities enhance customer equity? $\mathrm{Na}$ empirical study of luxury fashion brand. Journal of bussiness Research, 65(10), 14801486.

Kim, E. E. K.; Mattila, A. S.; Baloglu, S. (2011). Effects of Gender and Expertise on Consumers' Motivation to Read Online Hotel Reviews. Cornell Hospitality Quarterly 52(4) 399-406.

Kliatchko, J. (2008). Revisiting the IMC constructo: a revised definition and four pillars. International Journal of Advertising, v. 27, n. 1, p. 133-160.

Köche, J. C. (2004). Fundamentos de metodologia científica. 22. Ed. Petrópolis: editora Vozes.

Kostić, M.; Tončev, M. J.; Džamić, V.; Knežević, M. (2015). Economic and legal conceptual framework of viral marketing, Marketing, Vol. vol 46/2, No. 2, pp. 115 - 124, Dec.

Kotler, P; Kartajaya, H; Setiawan, I. (2010). Marketing 3.0: as forças que estão definindo o novo marketing centrado no ser humano. Elsevier.

Kotler, P.; Armstrong, G. (1998). Princípios de marketing. 7 ed., São Paulo: Prentice Hall do Brasil.

Kotler, P. (2000). Administração de Marketing - 10a Edição, $7^{\mathrm{a}}$ reimpressão - Tradução Bazán Tecnologia e Linguística; revisão técnica Arão Sapiro. São Paulo: Prentice Hall.

Kotler, P. (2012). Marketing Management: Analysis, Planning, Implementation, and Control, 14th ed., Prentice Hall, New Jersey.

Kozak, M. 2002. "Comparative Analysis of Tourist Motivations by Nationality and Destinations". Tourism Management 23 (3): 221-232.

Labsomboonsiri, S.; Mathews, S.; Luck, E. (2017). An investigation of problem-solving support and relaxation motivations on e-WOM. Journal of Marketing Communications 23 (3), 273-292

Lakatos, E. M.; Marconi, M. A. (1989). Metodologia científica. São Paulo: Atlas.

Laroche, M.; Habibi, M. R.; Richard, M. O.; Sankaranarayanan, R. (2012). The effects of social media based brand communities on brand community markers, value creation practices, brand trust and brand loyalty. Computers in human behavior, v. 28., n. 5, p 1755-1767, set.

Lévy, P. (1999). Cibercultura. Tradução de Carlos Irineu da Costa. São Paulo: Editora 34.

Lin, H. F. 2007. "Effects of Extrinsic and Intrinsic Motivation on Employee Knowledge Sharing Intentions." Journal of Information Science 33 (2): 135-149. 
Lu, W.; Stepchenkova, S. (2015). User-generated content as a research mode in tourism and hospitality applications: Topics, methods, and software. Journal of Hospitality Marketing \& Management, 24(2), 119-154.

Lüders, M.; Brandtzæg, P. B. (2017). 'My children tell me it's so simple': A mixedmethods approach to understand older non-users' perceptions of Social Networking Sites. new media \& society, Vol. 19(2) 181-198.

Lunenfeld, P. (2000). The digital dialetic: new essays on new media. Cambridge: MIT Press.

Luyt, B.; Chom, Y. H.; Ng, K. P.; Lim, J. (2011). Public Library Reading Clubs and Singapore's Elderly. Libri, Vol. 61, pp. 205-210, September

Macias, W. (2003). A preliminary structural equation model of comprehension and persuasion of interactive advertising brand web sites. Journal of Interactive Advertising, v. 03 , n. 02 , p. $36-48$, mar.

Malhotra, N. K. A. (2011). Pesquisa de marketing: foco na decisão. 3 ed. São Paulo: Pearson Prentice Hall.

Mahajan, V.; Muller, E.; Kerin, R. A. (1984). Introduction strategy for new products with positive and negative word-of-mouth. Management Science, v. 30, n. 12, p. 1389-1404, dec.

Manovitch, L. (2001). The Language of new media. Cambridge; The MIT Pres.

Mansfield, E. (1961). Technical change and the rate of imitation. Econometrica: Journal of the Econometric Society, v. 29, n. 4, p. 741-766.

Martins, C. A. (2012). Motivações para compra de artigos de luxo pela internet: um Estudo exploratório. Tese (mestrado em administração). Universidade de São Paulo, São Paulo, 2012. Disponível em: https://www.teses.usp.br/teses/disponiveis/12/12139/tde12082013-175229/pt-br.php. Acesso em: 09 junho 2016.

Maslach, C.; Stapp, J.; Santee, R. T. (1985). Individuation: conceptual analysis and assessment. J Pers Soc Psychol; 49(3):729-38.

Matos, C. A.; Rossi, C. A. V. (2008). Word-of-mouth communications in marketing: a meta-analytic review of the antecedents and moderators. Journal of the Academy of Marketing Service, 36(4), 578-596.

Mayring, P. (2014). Qualitative Content Analysis. Theoretical Foundation, Basic Procedures and Software Solution. Klagenfurt: Beltz.

McMellon, C.A.; Schiffman, L.G. (2000), "Cybersenior mobility: why some older consumers may be adopting the Internet", Advances in Consumer Research, Vol. 27, pp. 139-44. 
Midgley, D. F. (1983). Patterns of interpersonal information seeking for the purchase of a symbolic product. Journal of Marketing Research, v. 20, p. 74-83, feb.

Montero, I. (2005). El interés de las personas mayores por la edu cación: Qué educación. Estudio de Campo. Granada: Editorial Universidad de Granada. Tesis doctoral.

Moschis, G. P. (2003). Marketing to older adults: an updated overview of present knowledge and practice. Journal of consumer marketing, Vol. 20 NO. 6.

Moschis, G. P., Mathur, A. (2006). Older consumer responses to marketing stimuli: The power of subjective age. Journal of Advertising Research, 46(3), 339-346.

Moreno, A.; Navarro, C.; Tench, R.; Zerfass, A. (2015). Does social media usage matter? An analysis of online practices and digital media perceptions of communication practitioners in Europe. Public Relations Review 41. p. 242-253.

Murray, J. (2001). Hamlet on the holodeck: the future of narrative in cyberspace. Cambridge: MIT Press.

Muniz, k. M.; Feuser, J. L. (2012). As mudanças na comunicação mercadológica e realidade dos profissionais da área no Brasil. PPGCOM ESPM - Escola Superior de Propaganda e Marketing - São Paulo - 15 e 16 outubro.

Nickels, W. G.; Wood, M. B. (1999). Marketing: relacionamentos, qualidade e valor. Rio de Janeiro: LTC.

Nielsen - disponível em: http://www.nielsen.com/br/pt/press-room/2014/Idosos-jaficam-mais-tempo-em-casa-no-computador-do-que-os-jovens.html - acesso em 02 de março de 2017.

Nishijimaa, M.; Ivanauskasb, T. M.; Sarti, F. M. (2017). Evolution and determinants of digital divide in Brazil (2005-2013). Telecommunications Policy. Volume 41, Issue 1, Pages 12-24.

Ogden, J. R.; Crescitelli, E. (2007). Comunicação integrada de marketing: conceitos, técnicas e práticas. São Paulo: Pearson Prentice Hall.

Okada, S. I.; Souza, E. M. S. (2011). Estratégias de marketing digital na era da busca. REMark - Revista Brasileira de Marketing, São Paulo, v. 10, n. 1, p 46-72, jan./abr.

Oliveira, V. M.; Martins, M. F.; Vasconcelos, A. C. F. (2012). Entrevistas "em profundidade" na pesquisa qualitativa em administração: pistas teóricas e metodológicas. Simpoi.

Oliver, R. L. (1980). A Cognitive Model of the Antecedents and Consequences of Satisfaction Decisions. Journal of Marketing Research, 17, 460-9.

Oñate, C. G.; Peyró, C. F.; Lorenzo, F. C. (2015). Use, Consumption and Knowledge of New Technologies by Elderly People in France, United Kingdom and Spain. Comunicar, n. 45, v. XXIII, Media Education Research Journal. 
Organização Mundial da Saúde - OMS - disponível em www.who.int - acessado em 13 de fevereiro de 2017.

Park, C.; Lee, T. M. (2009). Information direction, website reputation and eWOM effect: a moderating role of product type. Journal of business research. 62(1). 61-67.

Peral, B. P.; Gaitán, J. A.; Ramos, A. F. V. (2015). From Digital Divide to Psycho-digital divide: Elders and Online Social Networks. Comunicar, n. 45, v. XXIII, Media Education Research Journal.

Pfeil, U., Arjan, R., \& Zaphiris, P (2009). Age Differences in Online Social Networking - A Study of User Profiles and the Social Capital Divide among Teenagers and Older Users in MySpace. Computers in Human Behavior, 25, 643-654.

Phelps, J.; Lewis, R.; Mobilio, L.; Perry, D.; Raman, N. (2004). Viral marketing or electronic word of mouth advertising: examining consumer responses and motivations to pass along email. Journal of Advertising Research, [S.I.], v. 44, n. 4, p. 333-348, dez.

Phillips, L. W., Sternthal, B. (1977). Age differences in information processing: A perspective on the aged consumer. Journal of Marketing Research, 14, 444-457.

Pires, V. C. (2003). A evolução da comunicação boca a boca. RIMAR - Revista Interdisciplinar de Marketing, v.2, n.1, p. 35-47, Jan./jun.

Polyak, I. (2000). The center of attention. American Demographics, Vol. 22 No. 11, November, pp. 30-2.

Price, L.L.; Feick, L.F. (1995). Guskey A. Everyday market helping behavior. J Public Policy Mark;14(2):255-66.

Raguseo, E.; Vitari, C. (2017). The effect of brand on the impact of e-WOM on hotels' financial performance. International Journal of Electronic Commerce. Volume 21, Issue 2, 1 July.

Recuero, R. (2009). Redes sociais na internet. Porto Alegre: Sulina.

Reynolds, F. D.; darden, W. R. (1971). Mutually adaptive effects of interpersonal communication. Journal of Marketing Research, v. 8, p. 449-454, nov.

Richardson, R. J. (2007). Pesquisa social: métodos e técnicas. 3 ed. São Paulo: Atlas.

Richins, M. L. (1983). Negative word-of-mouth by dissatisfied consumers: a pilot study. Journal of Marketing, v. 47, p. 68-78, win.

Riquelme, I. P.; Román, S.; Iacobucci, D. (2016). Consumer's perceptions of online and off-line retailer deception: A moderated mediation analysis. Journal of interactive marketing 35. 16-26. 
Riley, L. S., Kohlbacher, F.; Hofmeister, A. (2015). Baby Boomers of different nations: identifying horizontal international segments based on self-perceived age. International Marketing Review, 32(3/4), 245-278.

Roesch, S. M. A. (1999). Projetos de estágio e de pesquisa em administração: guia para estágios, trabalhos de conclusão, dissertações e estudos de caso. São Paulo: Atlas.

Rogers, E. (1995). Diffusion of Innovations. New York: Free Press.

Rosen, E. (2001). Marketing boca a boca: como fazer com que os clientes falem de sua empresa, seus produtos e serviços. São Paulo: Futura.

Royle, J.; Laing, A. (2014). The digital marketing skills gap: Developing a Digital Marketer Model for the communication industries. International Journal of Information Management. Volume 34, Issue 2, April, Pages 65-73.

Rubin, R. B.; Rubin, A. M. (1992). Antecedents of interpersonal communication motivation. Communication Quartely; 40(3): 305-17.

Rudiger, F. (2011). As teorias da cibercultura. Porto Alegre: Sulina.

Salaverría, R. (2005) Redacción periodística en Internet. Pamplona: EUNSA.

Schutz, W. C. (1966). FIRO: A three dimensional theory of interpersonal behavior. New York: Holt, Rinehart, \& Winston.

Scopus - disponível em https://www.scopus.com

Secretaria nacional de promoção defesa dos direitos humanos- disponível em: www.sdh.gov.br/assuntos/pessoa-idosa/dados-estatisticos/dados-sobre-oenvelhecimento-no-brasil. Acesso em 03 de março de 2017.

Selltiz, C.; Wrightsman, L; Cook, S.; Kidder, L. (1975). Métodos de pesquisa nas relações sociais. 2. ed. São Paulo: EDPVEDUSP.

Silva, A. M. A.; Vieira, F. G. D.; Pépece, O. M. C. (2012). Comunicação integrada de marketing: um estudo descritivo sobre o mercado de farmácias. Perspectivas Contemporâneas, v. 7, n. 1, p. 141-162, jan./jun.

Silvers, C. (1997). Smashing old stereotypes of 50-plus America. Journal of Consumer Marketing, 14, 303-9.

Shimp, T.A. (2009). Comunicação integrada de marketing: propaganda e promoção. Porto Alegre: Bookman.

Smola, K. W.; Sutton, C. D. (2002). Generational Differences: revisiting generational work values for the new millenium. Journal of Organizational Behavior, v.23, p.363-382. 
Standing, C.; Holzweber, M.; Mattsson, J. (2016). Exploring emotional expressions in eword-of-mouth from online communities. Information Processing and Management 52 721-732.

Sundaram, D. S., Mitra, K.; Webster, C. (1998). Word-of-mouth communications: a motivational analysis. Advances in consumer research, 25, 527-531.

Szmigin, I., Carrigan, M. (2001). Learning to love the older consumer. Journal of Consumer Behaviour, 1, 22-34.

Swan, J. E., Oliver, R. E. (1989). Postpurchase communications by consumers. Journal of Retailing, 65, 516-33.

Tang, Q.; Zhao, X; Liu, S. (2016). The effect of intrinsic and extrinsic motivations on mobile coupon sharing in social network sites: the role of coupon proneness. Internet research, Vol. 26.

Terra, C. F. (2011). Usuário-mídia: a relação entre a comunicação organizacional e o conteúdo gerado pelo internauta nas mídias sociais. Tese (Doutorado em Interfaces Sociais da Comunicação). Escola de Comunicações e Artes, Universidade de São Paulo, São Paulo, 2011. Disponível em: $<$ http://www.teses.usp.br/teses/disponiveis/27/27154/tde-02062011-151144/>. Acesso em: 09 junho 2016.

Torres, C. (2009). A Bíblia do Marketing Digital. 2 ed. São Paulo. Novatec.

Treem, J. W., \& Leonardi, P. M. (2012). Social media use in organizations: Exploring the affordances of visibility, editability, persistence, and association. Communication Yearbook, 36, 143-189.

Vallerand, R. J. 2000. "Deci and Ryan's Self-Determination Theory: A View from the Hierarchical Model of Intrinsic and Extrinsic Motivation”. Psychological Inquiry 11 (4): 312-318.

Valor. Disponível em: http:/www.valor.com.br/brasil/4513070/mais-da-metade-dapopulacao-brasileira-acessa-internet-aponta-ibge. Acessado em 20 de abril de 2015.

Vergara, S. C. (2012). Métodos de coleta de dados no campo. 2 ed. São Paulo: Atlas.

Vignoles, V. L.; Chryssochoou, X; Breakwell, G. M. (2000). The distinctiveness principle: identity, meaning, and the bounds of cultural relativity. Personal Soc Psychol Rev;4(4): 337-54.

Wasserman, C.; Grande, T. P. F.; Machado, L. R.; Behar, P. A. (2012). Redes sociais: um novo mundo para os idosos. Revista novas tecnologias na educação. V.10, n.1

Web of Science - disponível em https://www.webofknowledge.com

WEF - World Economic Forum (2011). Global Population Ageing: Peril or Promise? Global Agenda Council on Ageing Society. (http:// -goo.gl/f65RVZ). 
Weiser, E. B. (2001). The Functions of Internet Use and Their Social and Psychological Consequences. Cyberpsychology \& Behavior, 4, 723-43.

Wright, D. K., Hinson, M. D. (2012). Examining how social and emerging media have been used in public relations between 2006 and 2012: A longitudinal analysis. Public Relations Journal, 6(4), 1-40.

Zhang, T.; Omran, A.; Cobanoglu, C. (2017). Generation Y's positive and negative eWOM: use of social media and mobile technology. International Journal of Contemporary Hospitality ManagementVolume 29, Issue 2, 2017, Pages 732761.

Zikmund, W. G. (2006). Princípios da pesquisa de marketing. São Paulo: Pioneira Thomson Learning. 


\section{APÊNDICE 1}

\section{Protocolo de pesquisa}

\section{1) Visão geral do projeto de entrevista em profundidade}

A- Título:

Comunicação boca a boca em meio digital: um estudo exploratório sobre o comportamento do público idoso

B - Pesquisadores:

Prof. Dr. Edson Crescitelli

Telefone: (11) 3818-5842

Currículo lattes: http://lattes.cnpq.br/7652151522272485

Profa. Esp. Priscilla Santos Faria

Telefone: (11) 99518-3307

Currículo lattes: http://lattes.cnpq.br/7157467936211133

C - Problema de pesquisa:

Como os idosos se comportam no meio digital em relação à comunicação boca a boca?

D - Objetivo de pesquisa:

Compreender as motivações para o boca a boca em meio digital dos usuários de internet idosos.

\section{2) Método da pesquisa de campo}

A - Aspectos metodológicos:

Trata-se de uma pesquisa com natureza exploratória e qualitativa, com aplicação de entrevistas em profundidade e observação estruturada (detalhamentos no item três desta dissertação).

B - Fontes de evidências:

Entrevistas dirigidas;

Observações. 
C - Principais instrumentos de coleta de dados:

Roteiro de entrevistas semiestruturado e observações do compartilhamento de mensagens das páginas do Facebook dos usuários idosos de internet.

D - Relação dos entrevistados:

Usuários idosos de internet.

a) Janete Maria de Jesus;

b) Ademir José de Souza;

c) Maria Vicentina Giovanini;

d) Maria Raimunda Pereira da Silva;

e) Manuela Mazini;

f) IM;

g) $\mathrm{MB}$;

h) SM;

i) $\mathrm{AV}$;

j) JO.

\section{3) Procedimento operacional de pesquisa de campo:}

A - Executores da pesquisa:

Pesquisadora - Priscilla Santos Faria

Orientador - Edson Crescitelli

B - Agendamento da entrevista:

Para este estudo adotou-se o conceito de idoso da OMS (Organização Mundial da Saúde), em que todos seres humanos que possuem 60 anos ou mais estão enquadrados. Os idosos selecionados por conveniência precisavam ter uma página ativa no Facebook. O número de entrevistados foi definido com base no ponto de saturação ou redundância das respostas, conforme Godoi e Mattos (2006). Os respondentes foram indicados pelos participantes da pesquisa, num processo conhecido como "bola de neve" (ZIKMUND, 2006). Após o primeiro contato por telefone com o idoso usuário de internet, a carta convite foi enviada, e a entrevista foi agendada. Um pouco mais próximo da entrevista uma carta de confirmação de entrevista de pesquisa foi enviada ao respondente.

C - Carta convite de pesquisa de campo

Apêndice 2

D - Carta de confirmação de entrevista de pesquisa

Apêndice 3

\section{4) Itens de investigação organizados por subitens de análises}


1 - Motivações para a comunicação boca a boca

1.1 A necessidade de fazer parte de um grupo;

1.2 A necessidade de ser individualista;

1.3 A necessidade de ser altruísta, e;

1.4 A necessidade de crescimento pessoal.

2 - Dados do entrevistado

5) Análise das entrevistas em profundidade 


\section{APÊNDICE 2}

Carta convite de pesquisa de campo

\section{Universidade de São Paulo \\ Faculdade de Economia, Administração e Contabilidade}

São Paulo, de de 2017.

Prezado (a)

Venho por meio desta convidá-lo para participar de um estudo exploratório por mim desenvolvido com base em pesquisas realizados no mestrado da USP - Universidade de São Paulo.

O objetivo deste estudo é compreender as motivações para o boca a boca em meio digital dos usuários idosos de internet. $\mathrm{O}$ estudo estará baseado em pesquisas sobre as teorias já escritas sobre o tema e em uma pesquisa empírica feita por meio de entrevistas em profundidade com idosos usuários de internet que possuam Facebook, e os resultados da pesquisa servirão de base para a elaboração da minha dissertação de mestrado.

Sua participação é de bastante relevância para a conclusão do estudo. O principal interesse do estudo está em sua visão como usuário da internet e o compartilhamento das suas mensagens.

Uma vez aceito este convite, irei conduzir uma entrevista individual com tempo de duração estimado em 1 hora e 30 minutos. O trabalho está previsto para o mês de agosto de 2017. Após o término, caso queira, uma cópia de texto final lhe será entregue.

Grata desde já pela colaboração.

Saudações,

Priscilla Santos Faria

Mestranda de administração - linha de pesquisa em marketing USP - Universidade de São Paulo

FEA - Faculdade de Economia, Administração e Contabilidade 
APÊNDICE 3

\section{Confirmação de entrevista de pesquisa}

Obrigada por aceitar participar dessa pesquisa sobre comunicação boca a boca digital. Nossa conversa será realizada, conforme combinado, no dia _ _ _ $/ 2017$, às __ $\mathrm{h}$, no endereço duração aproximada de 1 h00.

e terá

Até lá!

Priscilla Santos Faria.

Mestranda em Administração (Marketing) pela FEA-USP 


\section{APÊNDICE 4}

\section{Roteiro semiestruturado para entrevista em profundidade - usuários idosos da internet}

Bom dia/ Boa tarde/ Boa noite,

Muito obrigada por aceitar participar dessa pesquisa. Teremos uma conversa de aproximadamente uma hora sobre comunicação boca a boca na internet. Para que eu possa analisar os dados depois, nossa conversa será gravada, tudo bem?

\section{(LIGA GRAVADOR)}

\section{Falar nome do entrevistado}

\section{PARTE 1: Confirmação do filtro}

Quantos anos você tem?

Quando foi a última vez que você compartilhou uma comunicação pela internet?

O que você compartilhou?

Em qual site?

Você usa o Facebook para compartilhar mensagens?

\section{PARTE 2: Entrevista}

(Etapa 1 - Introdução ao tema motivação para o boca a boca)

1 - Por favor, me conte o que te faz compartilhar mensagens.

2 - Isso é considerado uma motivação para que você realize a comunicação boca a boca?

3 - O que significa cada uma dessas motivações?

4 - O que elas representam?

5 - Você acredita que isso é fundamental para você compartilhar na internet?

6 - Faltou alguma motivação que influencia você a compartilhar?

7 - Imaginando que você vá enviar um conteúdo agora para algum contato seu, o que você consideraria importante para que houvesse o compartilhamento do conteúdo?

\section{(Etapa 2)}

- Inclusão/necessidade de fazer parte de um grupo/necessidade de atenção:

8 - Você acredita que compartilhar conteúdos com outras pessoas faz com que outras pessoas te aceitem? Isso é importante para você? Por quê?

9 - Você é reconhecido como pertencente a alguma ação ao realizar o boca a boca? 
10 - Seus compartilhamentos identificam seu modo ser pensar e agir?

\section{- A necessidade de marcar a individualidade:}

11 - Você acredita que seus compartilhamentos destacam você dos outros usuários da internet?

12 - Se você pudesse se destacar com algum compartilhamento você acredita que isso lhe faria compartilhar mais do que você já compartilha?

13 - Você compartilha coisas relacionadas a sua autoimagem?

\section{- Afeição/A necessidade de ser altruísta/mostrar apreciação e preocupação com os outros}

14 - Você compartilha conteúdo na internet para ajudar outras pessoas?

15 - Você acredita que seus compartilhamentos promovem acolhimento ou envolvimento emocional?

- Controle/A necessidade de crescimento pessoal/necessidade de exercer poder no ambiente social

16 - Você acredita que seu compartilhamento irá ajudar você a alcançar seus objetivos pessoais?

17 - Você acredita que o compartilhamento pode ajudá-lo no seu crescimento pessoal?

18 - Seu compartilhamento mostra que você faz a diferença em seu ambiente social?

\section{- Outras motivações}

19 - A sua relação com a empresa te motiva a compartilhar conteúdos positivos ou negativos sobre ela?

20 - Manter-se em comunicação ativa e aprender constantemente é uma motivação para que você realize a comunicação boca a boca?

21 - Seu compartilhamento pode causar a diminuição do isolamento digital e apoio à tomada de decisão dos idosos que você conhece?

22 - Você acha que seu compartilhamento é capaz de influenciar a tomada de decisão das pessoas? Isso é importante para que você compartilhe?

23 - Questões como recompensa econômica pode motivar você a realizar a comunicação boca a boca?

24 - Podemos visualizar alguns dos seus posts do Facebook? Vamos conversar sobre eles? 


\section{PARTE 3: Perfil dos respondentes}

Já estamos chegando ao fim. Gostaria de registrar algumas informações sobre o seu perfil.

25 - Qual nível de escolaridade?

26 - Profissão em que você trabalha ou trabalhou?

Pedir indicação de outros respondentes. (ZIKMUND, 2006)

Conhece alguém que realize a comunicação boca a boca pela internet que você acha que também participaria dessa pesquisa? (anotar nome, telefone e e-mail)

\section{AGRADECER E ENCERRAR.}




\section{APÊNDICE 5}

Histórico escolar e produção durante o período do mestrado.

1- Histórico escolar com as disciplinas cursadas e o conceito adquirido:

\begin{tabular}{|c|c|c|c|c|c|c|c|c|c|}
\hline Sigla & Nome da Disciplina & Inicio & Término & $\begin{array}{l}\text { Carga } \\
\text { Horária }\end{array}$ & Cred. & Freq. & Conc. & Exc. & Situação \\
\hline $\begin{array}{l}\text { EAD5911- } \\
6 / 2\end{array}$ & $\begin{array}{l}\text { Análise, Planejamento, Controle e Gestão Simulada de } \\
\text { Marketing (1) }\end{array}$ & $05 / 08 / 2013$ & $29 / 11 / 2013$ & 120 & 8 & 100 & B & $\mathrm{N}$ & Concluída \\
\hline $\begin{array}{l}\text { EAD5893- } \\
7 / 3\end{array}$ & Estratégia de Comunicação de Marketing & 03/03/2015 & $03 / 07 / 2015$ & 120 & 8 & 100 & A & $\mathrm{N}$ & Concluída \\
\hline $\begin{array}{l}\text { EAD5860- } \\
6 / 4\end{array}$ & Marketing Estratégico & $03 / 03 / 2015$ & $03 / 07 / 2015$ & 120 & 8 & 100 & A & $\mathrm{N}$ & Concluída \\
\hline $\begin{array}{l}\text { EAD 5822- } \\
11 / 4\end{array}$ & Metodologia de Pesquisa Aplicada à Administração I & $05 / 03 / 2015$ & $03 / 07 / 2015$ & 120 & 8 & 100 & A & $\mathrm{N}$ & Concluída \\
\hline $\begin{array}{l}\text { EAD5805- } \\
\quad 6 / 4\end{array}$ & Tópicos de Marketing & $04 / 08 / 2015$ & $27 / 11 / 2015$ & 120 & 8 & 87 & A & $\mathrm{N}$ & Concluída \\
\hline $\begin{array}{l}\text { EAD5960- } \\
2 / 2\end{array}$ & Marketing e a Evolução dos Mercados & $05 / 08 / 2015$ & $27 / 11 / 2015$ & 120 & 8 & 90 & A & $\mathrm{N}$ & Concluída \\
\hline $\begin{array}{l}\text { EAD5808- } \\
\quad 8 / 4\end{array}$ & Comportamento do Consumidor & $07 / 08 / 2015$ & $27 / 11 / 2015$ & 120 & 0 & - & - & $\mathrm{N}$ & $\begin{array}{l}\text { Matrícula } \\
\text { cancelada }\end{array}$ \\
\hline $\begin{array}{l}\text { Atividade } \\
\text { do } \\
\text { Programa }\end{array}$ & $\begin{array}{l}\text { Participou da Etapa de Estágio Supervisionado em Docência } \\
\text { do Programa de Aperfeiçoamento de Ensino junto à disciplina } \\
\text { EAD0644 - Decisōes de Promoção, Distribuiçâa/Canais, } \\
\text { ministrada a alunos da Graduaçâao do Curso de Administração } \\
\text { da Faculdade de Economia, Administraçãao e Contabilidade } \\
\text { da Universidade de São Paulo. (2) }\end{array}$ & $01 / 02 / 2016$ & $30 / 06 / 2016$ & - & 4 & - & - & - & - \\
\hline $\begin{array}{l}\text { EAD5967- } \\
1 / 2\end{array}$ & Pesquisa qualitativa em Marketing & 08/03/2017 & $30 / 06 / 2017$ & 120 & 0 & - & - & N & $\begin{array}{l}\text { Aguardando } \\
\text { avaliaçẫo }\end{array}$ \\
\hline
\end{tabular}

2- Bolsa de estudos:

- Estágio/monitoria PAE - USP: fevereiro até julho de 2016;

- CAPES: agosto de 2015 até agosto de 2017.

3- Livro publicado:

- Faria, P. S.; Borges, L. G. N. L. (2016). Planejamento e inteligência de marketing. Londrina: Editora e Distribuidora Educacional S.A., v.1.

4- Artigo publicado em revista:

- Faria, P. S.; Crescitelli, E. (2017). As três regras para a viralização de Gladwell: uma análise de vídeos do Youtube. Revista Uniítalo em Pequisa, v.7, n 3 .

5- Artigo enviado para publicação em revista: 
- Faria, P. S.; Mariano, S.; Sacramento, S.; Marinho, B. (2017). Mídias sociais como ferramenta de retenção de clientes em academias de ginástica. - Revista Remark.

6- Artigos apresentados em congresso

- Faria, P. S.; Mariano, S.; Sacramento, S.; Marinho, B. (2015). Mídias sociais como ferramenta de retenção de clientes em academias de ginástica. In Cigesp -Congresso Internacional de Gestão do Esporte, Rio de janeiro.

7- Participação em eventos científicos

- Treinamento sobre Web of Science, endnote web, Journal Citation Reports, Essencial Sciences Indicators e Incites pela Thomson Reuters, na USP/FEA, em 03-05-16.

- Organiação do SEMEAD 2016;

- Avaliação de banners de TCC na FEA/USP - junho 2015 e junho 2016;

- Participação de banca de TCC na ECA/USP - julho 2015 e junho 2016;

- XI Congresso Internacional de administração e marketing - ESPM 2016.

8 - Orientações de TCCs e iniciação científica em graduação, TCCs em pósgraduação. 